Volume 7 Number 1 January 2019

Online ISSN 2307-7921

Print ISSN 2070-0296

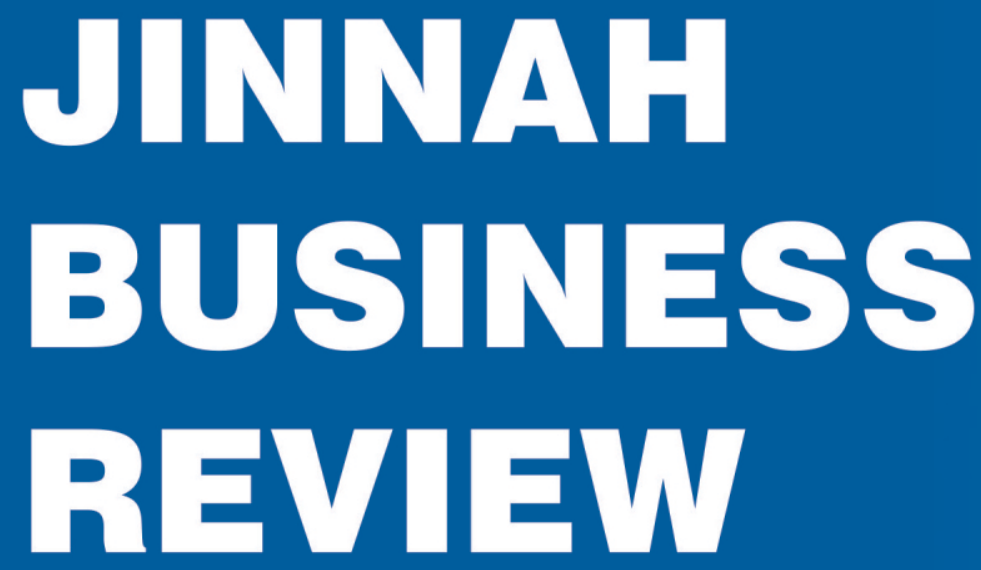

Dynamics of Exchange Rate and the Performance of Service Industry: The Nigerian Experience

Pakistan's Trade and Trading Partners' Using Gravity Model: A Static and Dynamic Panel Data

Impact of Infrastructure and Institutional Quality on Industrial Sector of Pakistan

Impact of Self Expressive Brands and Brand Attachment on Brand Advocacy: The Mediating Role of Brand Love

Prevalence of Post-Traumatic Stress Disorder and Its Impact on Job Satisfaction and Perceived Job Performance: Evidence from Afghanistan

Relationship of HR Practices and Career Path: a Perspective of Accounting Studies

Exploring the Unexplored Local Own Source Revenue: A Case Study of TMA Murree

Corporate Governance: Theory and Practice Impact of Corporate Governance on Firm Performance 



\section{JINNAH BUSINESS REVIEW VOLUME: 7 NUMBER: 1}

JANUARY 2019

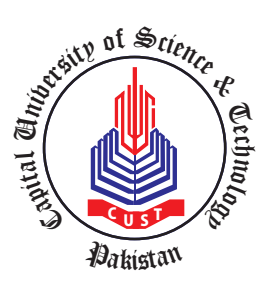




\section{Editor-in-Chief}

Professor Dr. Sajid Bashir

\section{ADVISORY BOARD}

\section{Dr. Charles Martin}

Professor, Wichita State University, USA

\section{Dr. Tackas Sandor}

Dean, Department of Business Corvinus University, Hungary

Dr. Asad Aman

Associate Professor, Lakehead University, Ontario, Canada

\section{Dr. Kubilay Özyer}

Professor, Gaziosmanpasa University, Turkey

Dr. Mazhar Mughal

Associate Professor, Pau Business School, France

Dr. Jose M. Merigo

Professor, University of Chile, Santiago, Chile

Dr. Valerie Earnshaw

Instructor, Harvard University, USA

Dr. Abdul Karim Khan

Assistant Professor, UAE University, UAE

Dr. Khurram Shahzad

Professor, Riphah International University, Islamabad, Pakistan

\section{Dr. Kashif-ur-Rehman}

Professor, Iqra University, Islamabad, Pakistan

Dr. Kamran Naqi

Professor, Hamdard University, Islamabad, Pakistan

\section{Dr. Arif Khattak}

Associate Professor, Bahria University, Islamabad, Pakistan

Dr. S. K. Shahzad

Assistant Professor, Air University, Islamabad

Dr. Muhammad Sarmad

Assistant Professor, SZABIST, Islamabad 


\section{Table of Contents}

1 Dynamics of Exchange Rate and the Performance of Service Industry: The Nigerian Experience 1

2 Pakistan's Trade and Trading Partners' Using Gravity Model: A Static and Dynamic Panel Data 11

3 Impact of Infrastructure and Institutional Quality on Industrial Sector of Pakistan 20

4 Impact of Self Expressive Brands and Brand Attachment on Brand Advocacy: The Mediating 27 Role of Brand Love

5 Prevalence of Post-Traumatic Stress Disorder and Its Impact on Job Satisfaction and Perceived 37 Job Performance: Evidence from Afghanistan

6 Relationship of HR Practices and Career Path: a Perspective of Accounting Studies

7 Exploring the Unexplored Local Own Source Revenue: A Case Study of TMA Murree

8 Corporate Governance: Theory and Practice Impact of Corporate Governance on Firm Perfor- 66 mance 



\title{
Dynamics of Exchange Rate and the Performance of Service Industry: The Nigerian Experience
}

\author{
Subair $^{* 1}$, K.,Tella S.A. ${ }^{2}, \&$ Somoye ${ }^{3}$ \\ ${ }^{1}$ Center for Global Entrepreneurship \& Sustainable Development, Indiana University- Purdue University, Indianapolis, \\ USA \& Department of Accounting, Banking \& Finance, Olabisi Onabanjo University, Ago-Iwoye, Ogun State, Nigeria \\ ${ }^{2}$ Olabisi Onabanjo University, Ago-Iwoye, Nigeria \\ ${ }^{3}$ Professor in the Department of Accounting, Banking \& Finance, Olabisi Onabanjo University, Ago-Iwoye, Nigeria
}

\begin{abstract}
The re-basing of the Nigerian economic data since 2013 has shown the growing relevance of the service sector to the economic development of Nigeria. The need to investigate the nexus between the service sector and macroeconomic variables become imperative in view of inadequate research attention in the past and the present desirable concern for policy shifts in favor of promoting activities in the sector. It is in this context that our paper considered the effects of exchange rate behavior on the performance of the service industry in Nigeria. More so that it is becoming increasingly clear that the openness of the Nigerian economy to the outside world and the seeming dollarization of earnings from economic activities, even with high local content, have varied impacts on economic behavior in many sectors of the economy. A comprehensive study was carried out to determine the relationship between the dynamics of exchange rate and the service industry activities. The data used include services, exchange rates, money supply, domestic credit, interest rate and inflation covering the period of 19812015. Using the ARDL, a 10\% point increase in exchange rate volatility and domestic credit increases service output growth (SER) by $0.68 \%$ and $5.15 \%$ respectively. The paper thus suggest that there must be reforms in government polices to remove barriers to entry by private investors into certain services in order to prevent market distortions and reduce cost of capital so as to enhance an integrated services-manufacturing industrial growth.
\end{abstract}

JEL Classification: F31, L81, L91, L96, G4

\section{Introduction}

Services sector has been identified to be the apex of economic development going by Clark (1977) economic growth model. The fundamental foundation of the model is resource based, such that when it is fully utilized, the economy only needs to maintain and sustain its tempo of development. Hence sustainable economic development is ensured since the economy has already transited from the primary to secondary industry. By implication and in consonance with the classical economic paradigm, full employment is attained and the economy only needs to be serviced. These services such as transportation, communication, insurance, banking and finance have all been regarded as aids to trade and germane to the functionality of the primary and secondary sectors. It is for this reason also that the service sector is referred to as the tertiary industry.

For an economy that is technologically backward, there is a need for procurement of imported inputs in order to facilitate the service industry, hence the need

*Corresponding author.

Email: kolasubair@gmail.com for continuous inflow of foreign exchange. But with respect to the high frequency rate of change in currency prices, there is that tendency for the cost in the provision of services to be on the high side. Such is the current predicament of the Nigerian economy, which experiences exchange rate surges and consequently increasing cost of service delivery. This has been attributed to frequent increase in the cost of procuring technical equipments from abroad due to the exchange rate volatility or the persistent fluctuations of Nigerian Naira.

In the heavily industrialized economies, service sector plays very pivotal role in lubricating their economies, as they are making consistent efforts in maintaining the development so far attained. In comparison to Nigeria and other developing economies, there has not been appreciable industrial development and their service industries have focused more on direct services and to aid production of consumer goods rather than on capital goods that could further generate inflow of foreign exchange. While the demand for foreign exchange towards the provision of direct 
consumer services increases, there has not been reciprocal inflow of foreign exchange in the same magnitude. It is this inadequate foreign exchange that catapults the conversion rate of Naira to other currencies of Nigerian trading partners. Whereas, in some developing countries like Gambia and Kenya, the service industry through tourism and hospitality services have been contributing enormous foreign exchange for their economies growth.

The significance of the services sector depends on its contributions to gross domestic product and its annual growth rate. For instance, in 2013 the share of the service sector in the Nigerian GDP was 57\% (Rutkowski et al., 2015) with an average annual growth rate of $3.7 \%$. It thus indicates that service sector activities are more prevalent in the Nigerian economy. It is the most easy employment absorber of the economy since the barrier to be engaged is flexible. Furthermore, except for highly technical requirements, it absorbs most of the low-skilled labour intensive technique of production. This is the reason why service delivery is poor and inconsequential in leading and spearheading economic growth in Nigeria.

Whereas, those economies that are high-skilled service sector tend to enhance high productivities in the agriculture and manufacturing, mining and construction industries. This is what has been experienced in the United States and Japan in 2011; While in United States, share of service sector in GDP was $78.6 \%$ that of Japan which was $72.7 \%$ as at the period of reporting. Rather than experienced acute shortages of goods and commodities due to high percentages of services sector contributions to their GDPs, their productivities in all other sectors increased continuously. With this scenario, this has continued to attract more capital inflows and hence more foreign exchange. Logically therefore, for developed economies that are endowed with highskilled services sector, foreign exchange is easily accessible compared to low skilled services sector in the developing economies. It is therefore apparent that there is a bivariate relationship between the exchange rate and the services sector of an economy.

\section{Literature Review}

The increase in services is a direct response to the rise in an economys level of income (Fuchs, 1980). This is because higher the level of income available to the economy, more the increase in demand for consumption and capital goods. Hence the need for services sector to lubricate the machines and organize other inputs needed for converting raw materials into intermediate and final goods for further production and final consumption. Services sector has continued to be the sin- gle largest and leading sector in providing more output and more employment to several people than any other sector. Perhaps the service sector has significantly been the source of impetus to the socio-economic growth of a country. On this note, Van Grasstek (1987) upholds that the classification of various services as a tertiary sector includes a non homogenous series of activities ranging from direct consumer services to sophisticated producer services such as data processing. In line with this view, Anyanwu (1997) regard services as one of the service-producing-industries which include all the services that are intangible in nature but very germane to the continuous production of tangible goods. The services sector thus includes all those economic activities outside the agriculture or manufacturing sectors (Iashmi and Kumar, 2012). Whereas, going by the Industrial Standard Classification (ISC) and by Khanna et al. (2016), the total industry includes agriculture, mining and quarrying, manufacturing, electricity and water supply and construction. Hence every other economic activity is regarded as services.

The predominance of the services sector in the Nigerian economy started in the wake of structural adjustment program (SAP), most especially with the high profitability experienced by the countrys financial sector. The liberalization of the sector enhances the opportunities of accessing the foreign exchange market, provides an avenue for proliferation of banks and bureau-de-charges. With this liberalization, the growth in production activities experienced, to some extent in Nigeria is attributed by Anyanwu (1997) to increase in government spending, which is also enhanced by fiscal decentralization through creation of additional local governments, thus necessitating additional services. It therefore implies in the context of Nigeria - a low income country that, the underdevelopment of the services sector is tantamount to impeding employment and anti production efforts. This is because services can hardly pollute the environment unlike manufacturing and agriculture.

Despite the reclassification of services into old and new categories, which include petty trading, domestic services, hotel and catering, and communication, insurance, legal, finance, real estate as well as education respectively, (Iashmi and Kumar, 2012) did not fail to reaffirm that the availability of quality services is important for the continuous survival or rapid growth of an economy. Their study identified the causes of the predominance of services to include urbanization, privatization and increase in demand for intermediate and final consumer goods. Furthermore it is crucial to accelerated economic growth, economic efficiency and global competitiveness. The socio-cultural and economic conditions have given more prominence to the service sector more so that it is trajectory to the efficien- 


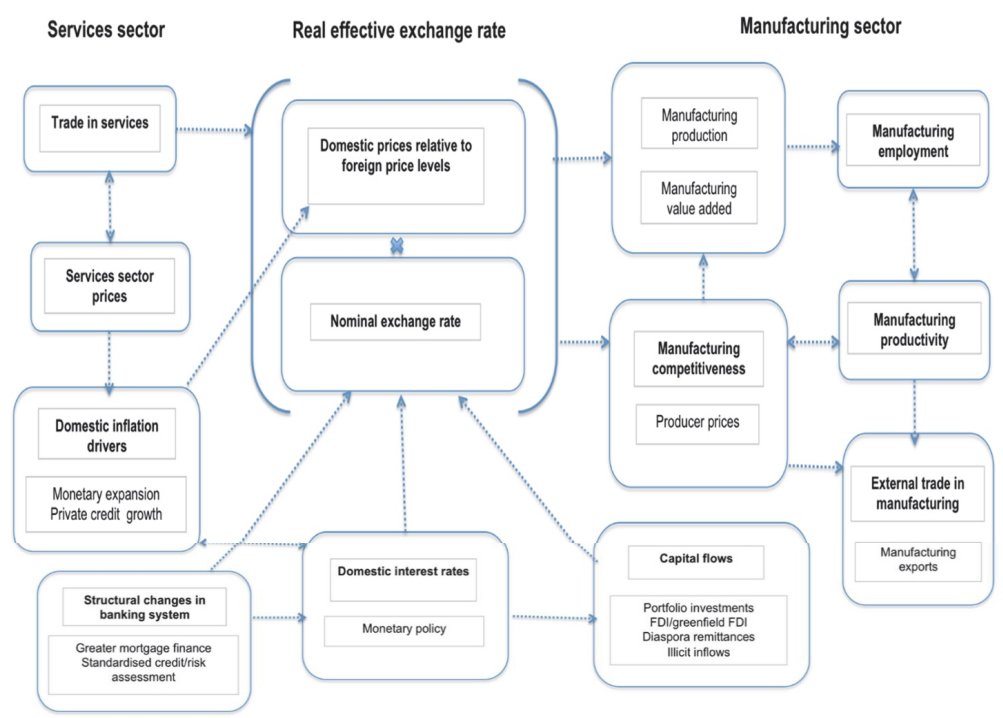

Figure 1: Services development, real effective exchange rate and economic transformation

Source: Adapted from Khanna et al. (2016).

cies in all other sectors of any economy.

Further buttressing the growth of the services sector is Eichengreen and Gupta (2011) in which the traditional services play significant role in developing countries due to their low levels of income. Whereas, as the level of income increases in the developed countries, the share of the services increases further, especially in the modern services like communication, finance, computer and business. It is for these dichotomized developed-developing countries responses that made Mukand and Rodrik (2015) to conclude that developing countries had only attained premature deindustrialization. This is because their manufacturing sector has reached the peak due to low productivity necessitated by the increasing share of activity and employment in the services sector.

Accordingly, emphasis on the services sector arises from accommodating the unemployed resources due to low productivity in the manufacturing sector, interindustry divisions of labor arising from manufacturing outsourcing and structural changes in the composition of aggregate demand (Khanna et al., 2016). In the real sense of it, the increasing demand for services is a growth-escalator because of the increasing wages from the services sector, thus facilitating high production in the manufacturing subsector of the industry. Perhaps the cheaper the services, the more they become integral lubricants in the process of raw inputs. This is the reason for Lanz and Maurer (2015) notion of servicification of manufacturing in terms of value added in developed and developing countries.

The cheap labor services most especially arising from its influx to other countries used frequently as production input tends to increase foreign exchange inflows through remittances to their home countries. This labor migration thus reduces the proportion of people living in poverty through investment-induced multiplier effect. Contrary to this, Khanna et al. (2016) uphold that services tending towards export-revenue maximization and capital inflows in isolation of the rest economy most especially in the ICT and financial services risk the danger of inflation, short term capital flows and low competitiveness in the agriculture and manufacturing subsectors. In accordance, the inflow of foreign exchange arising from the shifts of capital and labor away from agriculture and manufacturing hence resource transfer tends to distort growth through production of domestic non-tradable goods.

Empirically in the study conducted on the impact of exchange rate movements on services, Huang et al. (2014) using Tobit estimation procedure, confirmed that profits, survival and sales of services sector were affected just as it occurred in the manufacturing subsector in Canada. This was because as the domestic currency appreciated, the survival of less productive firms reduced and consequently lowered the sales of the surviving firms. Furthermore the study while using micro data from the communication, finance, insurance, real estates and insurance agent, business services and part of other services collated from the tax forms and longitudinal employment analysis projects (T2-LEAP), concluded that exchange rates significantly affected profits of service firms but not as much as experienced in the manufacturing sector.

Reasserting the existing relationship between ex- 
change rate and services sector in line with Huang et al. (2014) is the significance of export services to foreign exchange inflows in India. According to Iashmi and Kumar (2012), Indias export services increased from US5bnin1990toUS74bn in 2006. This exponential increase was attributed to the information technology and electronic services, which further increased the share of the country in global services trade. According to the authors, this was aided by the liberalization policy of the country, especially the migration from fixed to flexible exchange rate system. Furthermore Khanna et al (2015) studied also tilted towards the studies of Huang et al. (2014) and Iashmi and Kumar (2012) by examining finance, ICT, tourism and transport services as a major impetus to economic transformation in Kenya. The study particularly identified tourism as the sector that generates export revenues, value addition and many jobs directly or indirectly using data sourced from the Kenya National Statistical Office for the period of 2009 to 2013 and exhibited in Figure 1.

Figure 1 emphasizes how the services sector influences the real effective exchange rate and consequently leads to economic transformation. Figure 1 further demonstrates how services could be promoted to enhance linkages with manufacturing and or agriculture. In fact, a stronger real exchange rate of Kenyan Shillings was driven by the countrys transport sector due to banking sector inflows and rising corporate credit that benefited from the appreciation of the countrys currency.

Considering the fact that out of the available empirical studies reviewed in this paper, only Huang et al. (2014) used advanced model estimation technique, while other studies by Iashmi and Kumar (2012) as well as Khanna et al. (2016) used only descriptive statistics to analyze the collected data. Though the empirical studies so far are country-specific but none is yet to be found in relation to the Nigerian economy. It is against this background that this paper concentrated on deriving and estimating a robust model for establishing a concrete relationship between exchange rate and efficiency of the services sector in Nigeria.

\section{Methodology}

\subsection{Model Specification}

This study relies on the endogenous growth framework to investigate the relationship between the exchange rate and the service industry in Nigeria. The need to investigate the nexus between the service sector and macroeconomic variables become imperative in view of inadequate research attention in the past and the present desirable concern for policy shifts in fa- vor of promoting activities in the sector. Following the studies of Baggs et al. (2009), Ogun et al. (2012), and Iashmi and Kumar (2012), the empirical model adapted and modified for this study is stated as:

$$
\begin{gathered}
S E R_{t}=\phi_{0}+\phi_{1} E X R V+\phi_{2} M S_{t}+\phi_{3} D C P_{t}+ \\
\phi_{4} I N T_{t}+\phi_{5} I N F_{t}+\mu_{t}
\end{gathered}
$$

Where: SER is service output as a ratio of gross domestic product GDP); EXRV is exchange rate volatility; $M S$ is money supply as a ratio of GDP; DCP is domestic credit to private sector by banks as a ratio of GDP; INF is inflation rate; INT is interest rate; $\phi_{0}$ is constant; $\phi_{1-5}$ are slopes; $\mu$ is error term; and $t$ is time. Exchange rate volatility is measured using the generalized autoregressive conditional heteroskedasticity (GARCH) developed by Bollerslev (1986) and Taylor (2008) since it captures past values and also capable of forecasting the conditional variance of exchange rate. The conditional variance is specified as a function of three terms which is stated as:

$$
\sigma_{t}^{2}=\omega+\alpha \varepsilon_{t-1}^{2}+\beta \sigma_{t-1}^{2}
$$

Where; $\omega$ is a constant term; $\varepsilon_{t-1}^{2}$ (the ARCH term) is information about volatility from the previous period which is measured by the squared residual from the mean equation; and $\sigma_{t-1}^{2}$ (the GARCH term) is the last period's forecast variance.

The theoretical expectation of the model expects the slope of exchange rate to be positive or negative. An increase in exchange rate (price of a country's currency with respect to other currencies of the world) will make the domestic currency cheaper in the foreign exchange market. This depreciation in the domestic currency will make exports cheaper and imports expensive in the international market for goods and services. As a result of this, the demand for domestic goods and services would increase appreciably thus leading to a rise in the output of the service industry. The financial deepening indicators are expected to enhance the performance of the service industry. An increase in money supply will bring about an increase in the total money in circulation in the country. Invariably, it will increase aggregate demand and lead to a rise in productive activities and investment opportunities in the economy. This rise in the productive activities in the economy will lead to a rise in output of all sectors. However, domestic credit is expected to have a positive relationship with the growth in output of the services sector. Moreover, interest rate and inflation are expected to have negative relationship with output growth in an economy. 


\subsection{Data Sources and Estimation Tech- niques}

The data used are mainly secondary and were all sourced from the Central Bank of Nigeria (CBN) Statistical Bulletin, 2015 and National Bureau of Statistics (NBS). The period spans within 1981-2015. The study used the Autoregressive Distributed Lag (ARDL) bounds test by Pesaran et al. (2001) to investigate the impact of exchange rate volatility on the performance of the service industry in both long and the short run periods in Nigeria. Using this approach, the performance of the service industry is expressed as a function of the lagged value of itself and the current and the lagged values of the exchange rate volatility, financial deepening indicators, interest rate and inflation rate.

$$
\begin{gathered}
\Delta S E R_{t}=C_{0}+\sum_{p=1}^{n} \phi_{p} \Delta S E R_{t-p}+\sum_{p=1}^{n} \gamma_{p} \Delta E X R V_{t-p} \\
+\sum_{p=1}^{n} \lambda_{p} \Delta M S_{t-p}+\sum_{p=1}^{n} \omega_{p} \Delta D C P_{t-p}+\sum_{p=1}^{n} \theta_{p} \Delta I N T_{t-p} \\
+\sum_{p=1}^{n} \vartheta_{p} \Delta I N F_{t-p}+\delta_{1} S E R_{t-1}+\delta_{2} E X R V_{t-1} \\
+\delta_{3} M S_{t-1}+\delta_{4} D C P_{t-1}+\delta_{5} I N T_{t-1} \\
+\delta_{6} I N F_{t-1}+v_{t}
\end{gathered}
$$

Where: $\Delta$ is the first difference operator; $\delta_{1-6}$, are the long run multipliers; $\varphi, \gamma, \lambda, \omega, \theta, \vartheta$ are the short run dynamic coefficients of the underlying ARDL model in the equation; $v$ denotes the white noise error term. The Bounds cointegration test estimates equation 3 and restricting the parameters of the lag level variables to zero. Based on this equation, we tested the following null hypothesis $\left(H_{0}=\delta_{1}=\delta_{2}=\delta_{3}=\delta_{4}=\delta_{5}=\delta_{6}=0\right)$ of no cointegration or level relationship against the alternative hypothesis $\left(H_{1}=\delta_{1}=\delta_{2}=\delta_{3}=\delta_{4}=\delta_{5}=\delta_{6} \neq 0\right)$ that there is cointegration.

The F-test was used to test the existence of cointegrating relationship among the variables by testing the significance of the lag levels of the variables. The calculated F-statistic is compared with the two critical values for the upper and lower bounds tabulated by Narayan (2004). If the calculated value is greater than the upper bounds limit, there is long-run relation. There is no long run relationship if the calculated value is less than the lower bounds value. However, the result is inconclusive if it falls between the two bounds. Prior to the ARDL test, the unit root tests using the Augmented Dickey Fuller test were estimated to confirm the appropriateness of the estimation technique. The study also conducted diagnostic tests such as serial correlation, normality, and heteroskedasticity tests and the stability test.

\section{Results and Discussions}

\subsection{Descriptive Analysis}

Table 4.1 presents the descriptive analysis of the time series properties of the variables included in the model. The descriptive statistics was carried out among exchange rate volatility, financial deepening variables, inflation, interest rate and service sector output growth in Nigeria from 1981 to 2015. The table shows that the average value of service output (SER), money supply (MS) and domestic credit (DCP) to the size of the economy stood at $28.6 \%, 17.3 \%$ and $12.8 \%$ correspondingly. The mean value of the exchange rate volatility (EXRV) is 0.0673 which indicates that the country's currency is less volatile. The annual growth of interest rate (INT) and inflation rate (INF) stood at $12.9 \%$ and $20.4 \%$ correspondingly. The standard deviation of service output (SER), exchange rate volatility (EXRV), money supply (MS), domestic credit (DCP), interest rate (INT) and inflation rate (INF) from their respective long term mean values every year point at $3.81 \%, 0.302,5.84 \%, 6.55,4.16 \%$ and $18.5 \%$ respectively. The probability value of Jarque-Bera statistics for all variables shows their distribution level at mean zero and constant variance. It indicated that interest rate and service output are normally distributed among all the variables of interest.

Figure 2 illustrate the relationship between exchange rate volatility, interest rate and inflation rate in Nigeria. The figure reveals the volatile nature of Naira to dollar and how it fluctuates with interest rate and inflation throughout the periods. Thus, the directions of the trends are inconclusive moving positive and negative.

Figure 3 illustrate the relationship among service output, financial deepening indicators (money supply and domestic credit as percentage of GDP) and exchange rate volatility in Nigeria during the period of 1981 to 2015. The performance of the service sector improved over the periods as the trend (real service output as a percentage of real GDP) shows an upward movement. However, the relationship of the financial deepening indicators and exchange rate volatility are not clear enough to indicate whether it is positive or negative. The growth rate of service output to GDP fluctuates between $24.04 \%$ and $36.76 \%$.

Consequently, the inconclusiveness of the direction of our variables necessitates the need for an empirical analysis.

\subsection{Unit Root Test Results}

The time series properties of the variables using the Augmented Dickey Fuller (ADF) are presented in Table 4.2. This was carried out before establishing the longrun and short-run relationship and their estimates. The 
Table 4.1: Descriptive Statistics

\begin{tabular}{lcccccc}
\hline & SER & EXRV & MS & DCP & INT & INF \\
\hline Mean & 28.58250 & 0.067275 & 17.25827 & 12.84335 & 12.88189 & 20.35057 \\
Maximum & 36.76229 & 1.345124 & 37.95685 & 36.89332 & 26.00000 & 72.81000 \\
Minimum & 24.04271 & -0.157800 & 8.577088 & 5.917133 & 6.000000 & 4.670000 \\
Std. Dev. & 3.805036 & 0.302197 & 5.838363 & 6.547699 & 4.159491 & 18.44539 \\
Skewness & 0.874476 & 2.720339 & 1.655927 & 1.877912 & 0.733065 & 1.453957 \\
Kurtosis & 2.490928 & 10.77281 & 6.868021 & 6.880788 & 4.281029 & 3.829618 \\
Jarque-Bera & 4.838728 & 131.2757 & 37.81453 & 42.53481 & 5.527921 & 13.33533 \\
Probability & 0.088978 & 0.000000 & 0.000000 & 0.000000 & 0.063042 & 0.001271 \\
Obs. & 35 & 35 & 35 & 35 & 35 & 35 \\
\hline
\end{tabular}

Source: Authors' computation (2017)

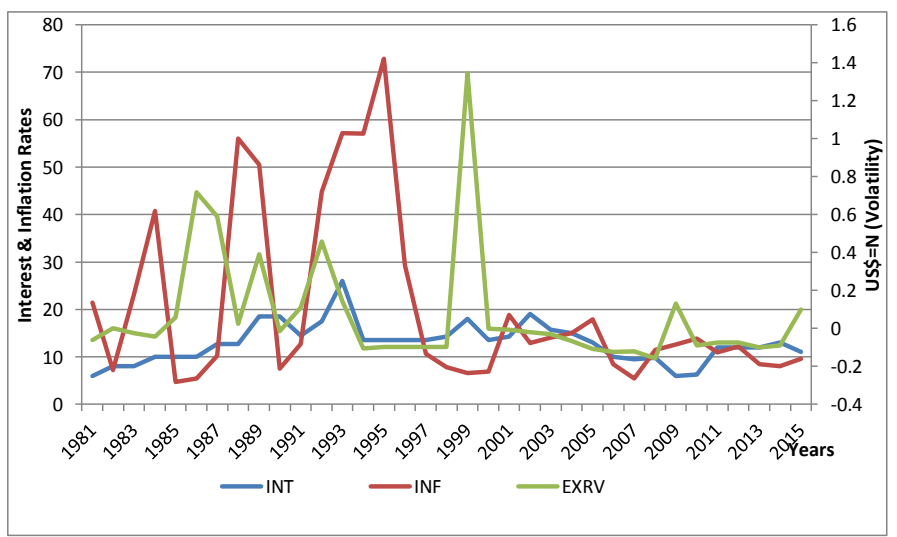

Figure 2: Exchange Rate Volatility, Inflation and Interest Rates

Source: Authors (2017)

results show that exchange rate volatility (EXRV) and inflation rate (INF) are stationary at levels [I(0)]. On the other hand, interest rate (INT), money supply (MS), domestic credit (DCP) and service output (SER) were reported to be stationary at first difference [I(1)]. Thus, these series are non-mean reverting at levels and do not converge to their long-run equilibrium until they are first differenced.

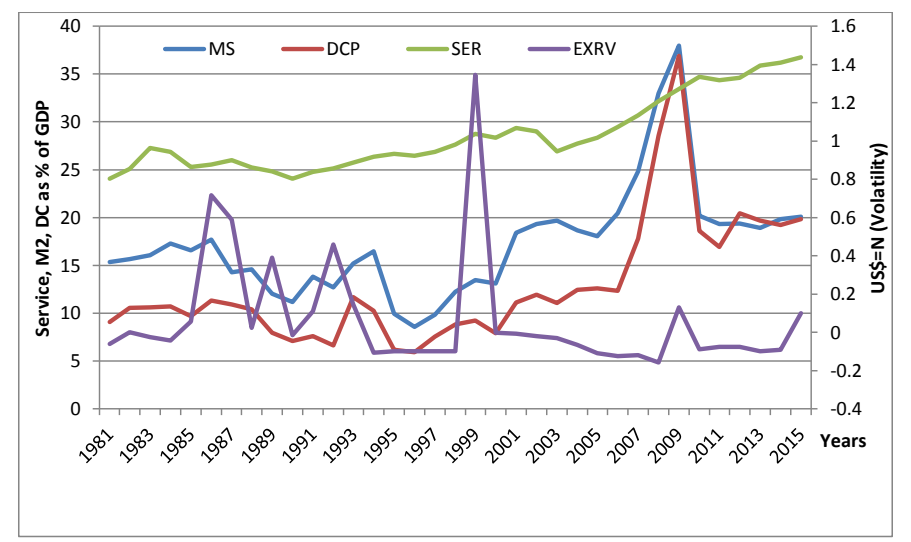

Figure 3: Exchange Rate volatility, Service Output, M2 and Domestic Credit

Source: Authors (2017) 
Table 4.2: ADF Unit Root Test Results

\begin{tabular}{lccc}
\hline Variables & \multicolumn{2}{c}{ ADF Tau Statistics } & Order of Integration \\
\hline \multicolumn{2}{c}{ Intercept } & Linear Trend & \\
\hline INT & $-3.0628(0)[-2.9511]^{* *}$ & $-6.3428(1)[-4.2733]^{*}$ & 1 \\
MS & $-5.4703(0)[-3.6463]^{*}$ & $-5.3824(0)[-4.2627]^{*}$ & 1 \\
DCP & $-5.8298(1)[-3.6537]^{*}$ & $-5.7631(1)[-4.2733]^{*}$ & 0 \\
EXRV & $-5.0314(0)[-3.6394]^{*}$ & $-5.3859(0)[-4.2529]^{*}$ & 0 \\
INF & $-2.9696(0)[-2.9511]^{* *}$ & $-4.1011(1)[-3.5530]^{* *}$ & 1 \\
SER & $-4.60847(0)[-3.6463]^{*}$ & $-4.8488(0)[-4.2627]^{*}$ & 1 \\
\hline
\end{tabular}

Note: * significant at 1\%; ** significant at $5 \%$; *** significant at $10 \%$ Mackinnon critical values and are shown in parenthesis. The lagged numbers shown in brackets are selected using the minimum Schwarz and Akaike Information criteria.

Source: Authors' computation (2017).

Empirical literature demonstrated that running a regression of a stationary series on non-stationary series has severe implications in drawing policy inference. The data series provides evidence for the use of Autoregressive Distributed Lag (ARDL) technique of analysis. As posited by Pesaran et al. (2001), ARDL is more suitable for variables with different orders of integration.

\subsection{ARDL Cointegration Result}

Table 4.3 presents the F-statistics estimates for testing the existence of long-run relationship between exchange rate volatility and service output growth in Nigeria. The estimated F-statistics of the normalized equations $\left(\mathrm{F}_{c a l}=5.2638\right)$ is greater than the lower and upper critical bound at $1 \%$ significance level. This implies that the null hypothesis of no long-run relationship is rejected at 5\% significance level. The implication of the result is that exchange rate volatility (EXRV), money supply (MS), domestic credit (DCP), interest rate (INT), inflation rate (INF) and service output growth (SER), all have equilibrium condition that keeps them together in the long-run.

\subsection{Results of Long-run Estimates of Ex- change Rate Volatility and Service Sec- tor Performance using the ARDL Ap- proach}

Table 4.4 revealed the long-run estimates between exchange rate volatility, financial deepening, interest rate, and inflation rate and service sector output growth in Nigeria. The long-run estimates suggested that exchange rate volatility (EXRV) and domestic credit (DC) have positive and significant impact on service performance (SER) in Nigeria and all these conform to the theoretical expectation. In magnitude terms, a $10 \%$ point increase in exchange rate volatil- ity and domestic credit increases service output growth (SER) by $0.68 \%$ and $5.15 \%$ respectively.

Furthermore, the table 4.4 revealed that money supply (MS), interest rate (INT) and inflation rate (INF) have negative impact on service output growth (SER) in Nigeria. This does conform to a priori expectation except money supply. A 10\% decrease in interest rate and inflation rate improve the performance of the service industry by $0.21 \%$ and $0.29 \%$ respectively. Also, if money supply increases by $10 \%$, the output growth of the service industry deteriorates by $5.72 \%$. The table shows that money supply was statistically significant respectively at $5 \%$ significance level.

\subsection{Error Correction Models using the ARDL Approach}

The short-run dynamic relationship between exchange rate volatility and service sector performance in Nigeria reveals the second part of the estimated ARDL model. The results were reported in Table 4.5. The lag lengths were selected based on Akaike Information Criterion (AIC).

The short-run estimates suggested that the first, second and third lags of service sector output have positive impact on the current service sector output in Nigeria. Thus, the short-run estimates of the exchange rate volatility, money supply, domestic credit, interest rate and inflation rate were also shown in the table. The error correction term indicates the speed of adjustment back to equilibrium in the model. The value is negative at $5 \%$ significance level. Specifically, the lag of the error correction term (ECT) was found statistically significant at $5 \%$ level with the co-efficient of -0.1291 . This indicates that $12.91 \%$ of the distortion in the short-run is corrected in the first year in attainting equilibrium or service output growth on the basis of the changes in exchange rate volatility, financial deepening variables, interest rate and inflation rate in Nigeria. 
Table 4.3: Existence of Long-Run Relationship between monetary policy and output growth

\begin{tabular}{lcc}
\hline Test Statistic & Value & K \\
\hline F-statistics (SER|EXRV, MS, DC, INT, INF) & 5.2638 & 5 \\
\hline Critical Value Bounds & & \\
\hline Significance & I0 Bound & I1 Bound \\
\hline $10 \%$ & 2.26 & 3.35 \\
$5 \%$ & 2.62 & 3.79 \\
$2.5 \%$ & 2.96 & 4.18 \\
$1 \%$ & 3.41 & 4.68 \\
\hline
\end{tabular}

Source: Authors' computation (2017).

Table 4.4: Long Run Coefficients [ARDL: 4,4,3,3,4,4]

\begin{tabular}{lcccc}
\hline \multicolumn{5}{l}{ Dependent Variable: Service output growth (SER) } \\
\hline Variables & Coefficients & Std. Error & t-Statistic & Prob. \\
\hline EXRV & 0.068320 & 0.006730 & 10.151318 & 0.0625 \\
MS & -0.572168 & 0.049475 & -11.564852 & 0.0549 \\
DCP & 0.515178 & 0.028966 & 17.785845 & 0.0358 \\
INT & -0.021248 & 0.046018 & -0.461732 & 0.7246 \\
INF & -0.029257 & 0.014531 & -2.013396 & 0.2935 \\
C & 3.708281 & 0.165140 & 22.455430 & 0.0283 \\
\hline
\end{tabular}

$* * * * *, *$ indicate $1 \%, 5 \%$ and $10 \%$ level of significance respectively

Source: Authors' computation (2017).

\subsection{Diagnostic and Stability Tests}

The post estimation tests examined for the suitability of our estimated ARDL model are heteroskedasticity, serial correlation, parameter stability and normality tests. The results are presented in Table 4.6. The results revealed that the ARDL model passed the serial correlation, normality test, heteroskedasticity and Ramsey RESET tests. They were also satisfactory for the ARDL model. This implies that the error terms are uncorrelated and normally distributed. They also have the same variance and the model is well specified.

\section{Conclusion and Recommenda- tions}

The significance of services sector to any economy is no doubt an embodiment of growth stimulation and economic development. It has remained a crucial source of engaging the unemployed and income generation most especially in the developing countries thereby reducing poverty. However it has rather deindustrialized the developing economies due to negligence of integrating services sector in stimulating the agriculture and manufacturing activities. Perhaps, there is no concrete linkage between the services sector and other sectors in the Nigerian economy, more so that those services that are highly technical and skilled have been subjected to exchange rate volatility. Hence the cost of inputs required for highly technical services increases and consequently affects the other sectors in the economy. In the overall context, service sector has failed to compliment the manufacturing subsector of the Nigerian industry.

In order to mitigate this problem of resource transfer from agriculture and manufacturing, there should be coordinated efforts by the government towards documentation of migrants to various parts of the world. In doing this, the Ministry of Labor and Productivity while taken the census of unemployed could assist in exporting the labor services such that remittances from abroad can be accounted for and properly channeled into small scale agriculture and manufacturing industry. This is because the remittances are bottom-up flows by providing lower sources of income to a much larger proportion of the population and potentially lead to more efficient resource allocation as private agents naturally work to maximize individual utility.

There is a need for encouraging and improving 
Table 4.5: Estimated Short-run Error Correction Model [ARDL: 4,4,3,3,4,4]

\begin{tabular}{|c|c|c|c|c|}
\hline \multicolumn{5}{|c|}{ Dependent Variable: Service output growth ( $\triangle$ SER) } \\
\hline Variables & Coefficient & Std. Error & t-Statistic & Prob. \\
\hline$\Delta(\operatorname{SER}(-1))$ & 1.368341 & 0.688508 & 1.987401 & 0.1178 \\
\hline$\Delta(\operatorname{SER}(-2))$ & 1.733219 & 0.952665 & 1.819337 & 0.1430 \\
\hline$\Delta(\operatorname{SER}(-3))$ & 1.196243 & 0.602432 & 1.985689 & 0.1180 \\
\hline$\Delta(\mathrm{EXRV})$ & 0.008722 & 0.008633 & 1.010300 & 0.3695 \\
\hline$\Delta(\operatorname{EXRV}(-1))$ & -0.096765 & 0.041219 & -2.347595 & 0.0787 \\
\hline$\Delta(\operatorname{EXRV}(-2))$ & 0.082306 & 0.034099 & 2.413725 & 0.0733 \\
\hline$\Delta(\operatorname{EXRV}(-3))$ & -0.047890 & 0.018306 & -2.616059 & 0.0590 \\
\hline$\Delta$ (MS) & -0.505013 & 0.216984 & -2.327424 & 0.0805 \\
\hline$\Delta(\mathbf{M S}(-1))$ & 0.463704 & 0.175054 & 2.648912 & 0.0570 \\
\hline$\Delta(\mathbf{M S}(-2))$ & 0.342574 & 0.125389 & 2.732078 & 0.0523 \\
\hline$\Delta(\mathbf{M S}(-3))$ & 0.274308 & 0.115694 & 2.370971 & 0.0767 \\
\hline$\Delta(\mathrm{DCP})$ & 0.538422 & 0.191396 & 2.813129 & 0.0482 \\
\hline$\Delta(\mathrm{DCP}(-1))$ & -0.281068 & 0.117079 & -2.400658 & 0.0743 \\
\hline$\Delta(\mathrm{DCP}(-2))$ & -0.323350 & 0.103736 & -3.117042 & 0.0356 \\
\hline$\Delta(\mathrm{DCP}(-3))$ & -0.162422 & 0.099419 & -1.633715 & 0.1777 \\
\hline$\Delta(\mathrm{INT})$ & 0.012609 & 0.029996 & 0.420370 & 0.6958 \\
\hline$\Delta($ INT(-1)) & -0.020458 & 0.053294 & -0.383867 & 0.7206 \\
\hline$\Delta($ INT(-2)) & 0.132941 & 0.085573 & 1.553532 & 0.1953 \\
\hline$\Delta($ INT(-3)) & 0.191440 & 0.110540 & 1.731857 & 0.1583 \\
\hline$\Delta(\mathrm{INF})$ & 0.002736 & 0.001137 & 2.406283 & 0.0739 \\
\hline$\Delta(\mathrm{INF}(-1))$ & 0.107047 & 0.126405 & 0.846851 & 0.4593 \\
\hline$\Delta(\mathrm{INF}(-2))$ & -0.058514 & 0.061050 & -0.958456 & 0.4085 \\
\hline$\Delta(\operatorname{INF}(-3))$ & -0.803951 & 0.153750 & -5.228953 & 0.0136 \\
\hline ECT(-1) & -0.129144 & 0.024342 & -5.305334 & 0.0131 \\
\hline
\end{tabular}

Source: Authors' computation (2017).

Table 4.6: Diagnostic and stability tests

\begin{tabular}{lc}
\hline Results & \\
\hline Serial Correlation: $1.6177[0.3525]$ & Normality Test: $1.0963[0.4708]$ \\
Functional Form: $1.3488[0.3974]$ & Heteroskedasticity Test: $1.7421[0.3317]$ \\
\hline
\end{tabular}

Source: Authors' computation (2017).

skilled based services in Nigeria. Towards this direction government should provide more funds to vocational education that will encourage local production of technical equipments needed to facilitate services provision. This will reduce dependence on for- eign exchange and hence reduce its negative impact on the performance of the services sector. Furthermore, the polytechnics in Nigeria should be restructured in terms of curriculum development and well equipped for the purpose of achieving its original goals of pro- 
viding pure technical education. Selected few could be upgraded also to degree-awarding institutions as it is being done in other developing countries.

It is important that government should offer support services and promotional measures for certain services in order to be integrated with the global economy. Such services in Nigeria include the information technology, tourism, banking insurance and real estate. All these would be avenues for inflows of foreign exchange that can further be invested in manufacturing and nonmanufacturing industry. Some of these measures may be removal of barriers to private investment in these services in order for competition to thrive. Perhaps reducing the regulatory barriers to foreign entry into certain services like information technology, real estate and insurance would eliminate market distortions and consequently reduce cost of capital through the inflows of foreign exchange.

Finally it is important that smooth interactions should be encouraged among the various service sectors. For the financial sector to be virile, it needs the ample support of an efficient and large information and communication technology while the tourism on its part also needs an efficient transportation system. It is therefore important that the exchange rate needed in these part of the services sector should be prevented from fluctuating so as to encourage investors and subsequently enhance growth in all other sectors of the economy. However, corruption should be mitigated by preventing round tripping and other sharp practices that could hamper the realization of government policies towards achieving strong services sector that would compliment other sectors and finally ensure economic growth and development in Nigeria.

\section{References}

Anyanwu, J. C. (1997). The structure of the Nigerian Economy (1960-1997). Joanee educational publishers.

Baggs, J., Beaulieu, E., and Fung, L. (2009). Firm survival, performance, and the exchange rate. Canadian Journal of Economics/Revue canadienne d'économique, 42(2):393-421.

Bollerslev, T. (1986). Generalized autoregressive conditional heteroskedasticity. Journal of econometrics, 31(3):307-327.
Clark, C. (1977). Population growth and land use. Springer.

Eichengreen, B. and Gupta, P. (2011). The two waves of service-sector growth. Oxford Economic Papers, 65(1):96123.

Fuchs, V. R. (1980). Economic growth and the rise of service employment.

Huang, H., Pang, K., and Tang, Y. (2014). Effects of exchange rates on employment in canada. Canadian Public Policy, 40(4):339-352.

Iashmi, P. and Kumar, S. (2012). Economic growth and impact of service's sector in india. International Journal of Business Management E Economic Research, 3(5).

Khanna, A., Papadavid, P., Tyson, J., and te Velde, D. W. (2016). The role of services in economic transformationwith an application to kenya. London: SET.

Lanz, R. and Maurer, A. (2015). Services and global value chains: Some evidence on servicification of manufacturing and services networks. Technical report, WTO Staff Working Paper.

Mukand, S. and Rodrik, D. (2015). The political economy of liberal democracy. Technical report, National Bureau of Economic Research.

Narayan, P. (2004). Reformulating critical values for the bounds F-statistics approach to cointegration: an application to the tourism demand model for Fiji, volume 2. Monash University Australia.

Ogun, O., Egwaikhide, F. O., and Ogunleye, E. K. (2012). Real exchange rate and foreign direct investment in subsaharan africa. some empirical results. Economía Mexicana. Nueva Época, 21(1).

Pesaran, M. H., Shin, Y., and Smith, R. J. (2001). Bounds testing approaches to the analysis of level relationships. Journal of applied econometrics, 16(3):289-326.

Rutkowski, R. et al. (2015). Service sector reform in china. Policy brief, (15-2).

Taylor, S. J. (2008). Modelling financial time series. world scientific.

Van Grasstek, C. (1987). Trade in services: Obstacles and opportunities', economic impact. 


\title{
Pakistan's Trade and Trading Partners Using Gravity Model: A Static and Dynamic Panel Data
}

\author{
Sana Ullah*1, Adiqa Kausar Kiani² ${ }^{2} \&$ Muhammad Imran ${ }^{3}$ \\ ${ }^{1}$ Quaid-i-Azam University, Islamabad, Pakistan \\ ${ }^{2,3}$ Federal Urdu University, arts, science and technology, Islamabad, Pakistan
}

\begin{abstract}
This paper examines Pakistans trade flows using a gravity model for the period 2002-2015. We have selected the following major trade partners: China, UAE, Saudi Arab, United States, Kuwait, Malaysia, Japan, India, Singapore, Afghanistan and Iran. In this research, we employed static and dynamic econometric approaches. The results from the two approaches are similar, which showed economic size and distance have played a crucial role in bilateral trade. Furthermore, political globalization was found to be significant and played a vital role during the study period. These variables confirm that the theoretical models, Pakistan and Pakistan trade partner with economic masses, political globalization, and distance strongly effect trade liaison.
\end{abstract}

Keywords: Trade, Gravity model. Bilateral trade

JEL classification: C20, F12.

\section{Introduction}

Trade is an integral part of the developmental process of an economy. With globalization, many nations have liberalized their bilateral trade and removed barriers from trade. Globalization may be defined as enhancement of economic integration, free mobility of capital, border share and mobility of labor, etc. Pakistan started bargaining several bilateral and economic regional trade agreements with border countries in last two and three decades. Also, in this situation through bilateral trade, they also improved the peoples standard of living (Suvankulov and Guc, 2012; Xuegang, 2008).

The role of economic regional integration and free trade agreements has become an important ingredient in economic development. Many studies provide the empirical evidence on positive correlation between the regional trading agreements, market size, geographical distance, common border, language, culture and trade flows (Anderson, 2011; Samy and Dehejia, 2011; Serrano and Pinilla, 2012). The ASEAN, EU, NAFTA and WTO are successful examples of economic integration. The economic regional integration has derived the free trade agreement and economic development. The worlds aggregate demand has been growing at a sluggish rate, during 2015, due to declining commodity prices and snowballing instability of financial market in major economies. However, growth of import demand in Europe is declining, and as well as a weak

*Corresponding author.

Email: sana_ullah133@yahoo.com

http://www.jbrc.pk aggregate demand in the United States and Japan also becoming a low demand of agricultural commodity. As a result, developing countries, such as Pakistan, have seen demand for their exports cripple in this era and lower export earnings. As we know that, Pakistan is an agricultural economy, its exports are most of the time leading on agricultural commodity, like cotton \& cotton manufactures, rice, etc, as shown in table 1.1.

Although larger part of Pakistans exports goods are going to western countries such as, UK, Germany, France, Italy and Spain, etc. Furthermore, other major imports are Afghanistan, China, UAE, and USA. The share of exports to western countries like France, Italy, Spain, UK etc. remained comparatively stagnant in latest era. The share of export to U.A.E is witness to the fact that China and India are capturing this market, and so share of Pakistani exports have declined, as shown in table 1.2.

In the past, Pakistans agricultural commodity had enormous demand in international markets, but nowadays shortage of water and lack of better pesticides, along with the failure to cope with the changing trends in world markets, have affected the agricultural commodity demand and exports. Pakistan also faces a stiff competition from India and China for agricultural products. Pakistan mostly exports rice, fish and fish preparations, fruits, cotton yarn, fabrics, chemicals and pharmaceuticals; leather manufactures goods to the other countries.

Pakistan mostly imports from the China that is 23\% 
Table 1.1: Pakistan's Major Exports (\% share)

\begin{tabular}{lcccccc}
\hline Commodity & $\mathbf{2 0 0 9 - 1 0}$ & $\mathbf{2 0 1 0 - 1 1}$ & $\mathbf{2 0 1 1 - 1 2}$ & $\mathbf{2 0 1 2 - 1 3}$ & $\mathbf{2 0 1 3 - 1 4}$ & $\mathbf{2 0 1 4 - 1 5}$ \\
\hline Cotton Manufactures & 50.6 & 52.9 & 49.6 & 51.6 & 53.1 & $\mathbf{5 4 . 5}$ \\
Leather** & 4.5 & 4.4 & 4.4 & 4.7 & 5.1 & 4.8 \\
Rice & 11.3 & 8.7 & 8.7 & 7.8 & 7.6 & 8.5 \\
Sub-Total of three Items & $\mathbf{6 6 . 4}$ & $\mathbf{6 6 . 0}$ & $\mathbf{6 2 . 7}$ & $\mathbf{6 4 . 1}$ & $\mathbf{6 5 . 8}$ & $\mathbf{6 7 . 8}$ \\
Other items & 33.6 & 34.0 & 37.3 & 35.9 & 34.2 & 32.2 \\
Total & $\mathbf{1 0 0 . 0}$ & $\mathbf{1 0 0 . 0}$ & $\mathbf{1 0 0 . 0}$ & $\mathbf{1 0 0 . 0}$ & $\mathbf{1 0 0 . 0}$ & $\mathbf{1 0 0}$ \\
\hline
\end{tabular}

**: Leather \& Leather Manufactured. Source: Pakistan Bureau of Statistics

Table 1.2: Major Export Markets (Rs. \& US\$ Billion \& Percentage share)

\begin{tabular}{|c|c|c|c|c|c|c|}
\hline \multirow[t]{2}{*}{ Country } & \multicolumn{3}{|c|}{ 2013-14 } & \multicolumn{3}{|l|}{ 2014-15 } \\
\hline & Rs. & US\$ & \%Share & Rs. & US\$ & \%Share \\
\hline U.S.A & 381.5 & 3.7 & 15 & 374.4 & 3.7 & 16 \\
\hline China & 249.0 & 2.4 & 10 & 219.9 & 2.2 & 9 \\
\hline U.A.E & 180.0 & 1.7 & 7 & 102.9 & 1.0 & 4 \\
\hline Afghanistan & 192.5 & 1.9 & 7 & 198.8 & 1.9 & 8 \\
\hline United Kingdom & 161.5 & 1.6 & 6 & 160.2 & 1.6 & 7 \\
\hline Germany & 117.9 & 1.15 & 5 & 119.0 & 1.2 & 5 \\
\hline France & 42.7 & 0.4 & 2 & 38.2 & 0.4 & 2 \\
\hline Bangladesh & 71.8 & 0.7 & 3 & 70.7 & 0.7 & 3 \\
\hline Italy & 75.6 & 0.7 & 3 & 67.6 & 0.7 & 3 \\
\hline Spain & 72.0 & 0.7 & 3 & 81.7 & 0.8 & 3 \\
\hline All Other & $1,039.0$ & 10.1 & 40 & 964.1 & 9.5 & 40 \\
\hline Total & $2,583.5$ & 25.1 & 100 & 2397.5 & 23.7 & 100 \\
\hline
\end{tabular}

Source: Pakistan Bureau of Statistics

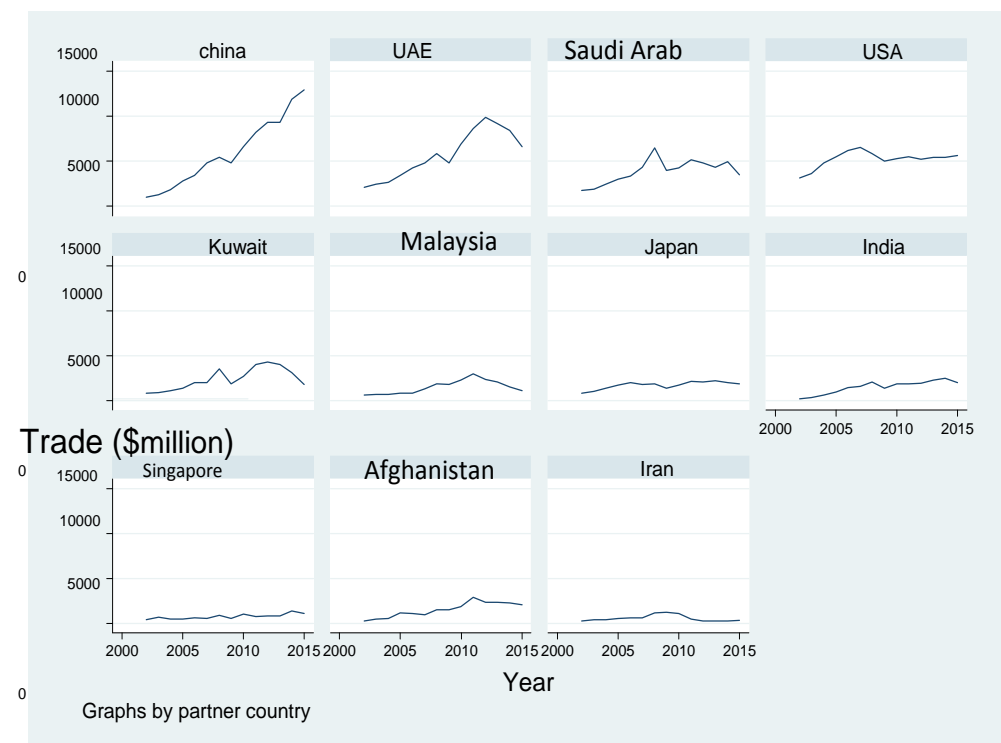

Figure 1: Bilateral trade between Pakistan and trade partners

\section{Source: Authors calculation}

in 2014-15. This ratio has massively increased in the last decade; in future this bilateral trade will also rise due to China-Pakistan Economic Corridor (CPEC). Pakistani imports are concentrated in a few markets like China, Saudi Arabia, Kuwait, UAE, where oil related commodities mostly imported from the Arabic countries. 
Table 1.3: Major Imports Markets (Rs. \& US\$ Billion \& Percentage share)

\begin{tabular}{lcccccc}
\hline Country & $\mathbf{2 0 1 3 - 1 4}$ & & \multicolumn{3}{c}{$\mathbf{2 0 1 4 - 1 5}$} \\
\hline U.A.E & Rs & US \$ & \% Share & Rs & US \$ & \% Share \\
China & 757.1 & 7.4 & 16 & 681.9 & 6.6 & 15 \\
Kuwait & 793.0 & 7.7 & 17 & 1053.0 & 10.2 & 23 \\
Saudi Arabia & 346.7 & 3.4 & 7 & 250.9 & 2.5 & 5 \\
Malaysia & 459.1 & 4.5 & 10 & 365.5 & 3.6 & 8 \\
Japan & 174.4 & 1.7 & 4 & 96.3 & 0.9 & 2 \\
India & 182.6 & 1.7 & 4 & 170.6 & 1.7 & 4 \\
U.S.A & 210.5 & 2.0 & 5 & 172.2 & 1.7 & 4 \\
Germany & 180.1 & 1.7 & 4 & 180.7 & 1.8 & 4 \\
Indonesia & 126.1 & 1.2 & 3 & 97.5 & 0.9 & 2 \\
All Other & 162.7 & 1.6 & 4 & 209.6 & 2.1 & 5 \\
Total & $1,238.2$ & 12.0 & 27 & 1366.0 & 13.3 & 29 \\
\hline
\end{tabular}

Source: Pakistan Bureau of Statistics

The share of oil importing countries has fallen 3 to 2 percent in latest period mainly due to declining of oil prices (see table 1.3). Bilateral trade between Pakistan and trade partners description is given in Figure 1. Pakistan imports Petroleum products, Iron, steel manufactures, Machinery (non-electrical), Electrical goods, and Chemicals products, etc. In next few years, the construction related activities may increase in public sector spending, for the infrastructure of CPEC. However, this rigorous study tried to examine the pattern of Pakistans trade with its partners using the static and dynamic model.

\section{Literature Review}

Gravity models are extensively used in empirical research on bilateral trade. The first attempts elaborate the trade flows by the economic size of the trading partners and distance is closely related to the innovations (Leibenstein, 1966; Pöyhönen, 1963). The purpose of this paper is to test the impact of main characteristics of a country and its geographical location to its partners through bilateral trade flows. Recent developments in literature show that very limited studies have done this type of analysis on South Asia region. There are few studies that used the gravity model for the purpose of Pakistan. At first, we briefly discuss the major findings of few studies are related to Pakistan. This meticulous study will attempt to fill this gap.

Khan and Mahmood (2000) used gravity model and checked bilateral trade in Pakistan and controlling the size of economic, geographical location, and cultural proximity. The trade volume is taken as the regress and variable. The independent variables are the product of per capita GNPs, product of GNPs, real exchange rate, tariffs, distance, official language, border share, and regional dummies for instance; ASEAN, NAFTA, SAARC and EU. The model includes ten commodities for 21 countries and using interval data. All the coefficients showed to be highly statistically significant excluding bordering country, which gives negative sign. One of the reasons may be historical conflict occurred between India and Pakistan in the last 65 years.

Some studies have recycled the gravity to analyze the impact of trade blocks. Butt et al. (2008) used panel data including the SAARC countries for main 19 sectors of the Pakistan economy. The results indicate that higher weight of export potential with trading partner countries under the trade blocks. In case of Bangladesh, Rahman et al. (2006) also used gravity model for panel groups. His major findings show that the size of economies, trade openness, per capita GNP and distance involved in the bilateral trade are positively significant in regression analysis. Same as, Montanari et al. (2008) have supported the Rahman et al. (2006) model, revealed that higher income stock has robust effect on the trade and vice versa.

The classical and new trade theory briefly explains the world trade and nowadays gravity model performing tremendously in international trade. Similarly, report by Butt et al. (2008) based on gravity model at the various sector. Most of the time, export volume is taken as a dependent variable and many set of dummies variable are included such as, common border, common language, conflict, geographical location and tariffs, etc. The study covers 15 major sectors for the years 2002 and 2003 and identifies the trade potential of two states in the context of Pakistan and India region. According to the report results, the trade potential is higher, if both countries were not engaged in war conflicts and removed the barriers in bilateral trade. They showed that, beverages, chemicals and tobacco products, food, leather products and textiles have high exis- 
tence of trade potential.

In the first part of the gravity literature, we focus on Pakistan- related studies that discussed the international trade and in the second part international studies at World level have been taken into account. In most of the international level studies, export are taken as a dependent variable (Kong and Kneller, 2016; Suvankulov and Guc, 2012; Trotignon, 2010; Ullah and Inaba, 2012). Similarly, some other studies used import as dependent variable (Abiad et al., 2014; Tumbarello, 2006; Westerlund and Wilhelmsson, 2011). Bussière et al. (2008) took the average of imports and exports between the two countries as the dependent variables.

Similarly; GDP, per capita GDP of the trade partners as well as distance are used as independent variables in nearly all studies in the literature (Abiad et al., 2014; Ranajoy et al., 2006; Suvankulov and Guc, 2012; Ullah and Inaba, 2012; Westerlund and Wilhelmsson, 2011). Within this context, numerous other variables that can be involved in the gravity equations, which can explain the real picture of international trade of Pakistan. For example, in addition to gravity models, they added some "multilateral resistance variables" in the equation. Baier and Bergstrand (2009) used distance and border share as a proxy for trade costs. However, dummy variables for other factors that can affect trade volume, like geographical area, cultural proximately and as well as free trade agreements and economic blocks such as ASEAN, SAARC, NAFTA, WTO, $\mathrm{EU}, \mathrm{ECO}$, etc. were added to the gravity models over time (Ranajoy et al., 2006; Trotignon, 2010; Ullah and Inaba, 2012).

In a nutshell, there are a huge number of empirical applications in different studies which used gravity model. Thornton and Goglio (2002) emphasized on importance of economics size, distance and common language in regional trade for ASEAN and found significant results. See also Rahman et al. (2006) for Bangladesh; Babetskaia-Kukharchuk and Maurel (2003) for EU; Anaman and Al-Kharusi (2003) for Brunei; Blomqvist (2004) for Singapore; Batra (2006) for India; Baroncelli (2007) for Pakistan-India; Minetti et al. (2018) for UK-EU which provide an extensive discussion on the role of bilateral trade and found results according to economic theory.

\subsection{The Gravity Model}

The Newton physics law is the first vindication of the gravity. The model has been generated from Newton's Law of Gravity (Leibenstein, 1966; Pöyhönen, 1963) used for the first time in international trade. Over the last fifty years, the gravity model has become the workhorse of the trade researchers. According to the model, the trade volume between countries, directly depends on size of economics and inversely related to distance in gravity model (Anderson, 2011; Balassa,
1966; Caves, 1981; Leibenstein, 1966; Pöyhönen, 1963; Toh, 1982) and also consider that geographical distance is an important determinant of gravity model and distance is also the proxy for transportation cost. Similarly, Rauch (1999) and Eichengreen and Irwin (1998) emphasized on border, common language should be considered in gravity equation. So, using these variables; the gravity equation can be written as:

$$
T_{i j}=G \frac{M_{i}^{\alpha} M_{j}^{\beta}}{D_{I J}^{\delta}}
$$

Where $\mathrm{i}=$ Pakistan; $\mathrm{j}=1,2 \ldots . .11$ (trade partners); Tij denotes the flow from country i to j. Mi and $\mathrm{Mj}$ are the sizes of economy of Pakistan and trade partners, normally measured as the GDP or GDP per-capita. Dij is the geographically distance between two regions. $G$ is a constant term. We apply logs on the gravity equation and we estimate the linear gravity equation has the following form:

$$
L n T_{i j}=\ln G+\alpha \ln M_{j}+\beta \ln M_{j}-\delta \ln D_{i j}
$$

Where $\ln G$ represents the intercept, while $\alpha, \beta$ and $\delta$ are elasticities of the economic sizes and distance variables. The static econometric model of Pakistan's trade takes the following representation:

$$
Y_{i t}=\beta_{0}+\beta_{1} X_{i t}+\mu_{1}+\varepsilon_{i t}
$$

Where $Y_{i t}$ is set of Pakistan's export, import and bilateral trade respectively and $X_{i t}$ is a set of regressor variable. Most of the variables are in the $\log$ form; is the unobserved individual specific effects ${ }^{\prime} i$ is idiosyncratic error and assumed to beE $\left(_{i t}\right)=0$; $\operatorname{Var}\left({ }_{i t}\right)=\sigma^{2}$. One of the shortcomings of fixed effect model does not include the time invariant variable, for instance geographical distance. To overcome this problem, we used random effect and Tobit in static model. In static gravity model, random and Tobit give more accurate results (Verbeek, 2004); although, unlike theoretical models of trade, which do not advise a dynamic specification, we decided to introduce a variation in static model, because in this static model there are problems with correlation and endogeneity of few independent variables. These problems were resolved by Arellano and Bond (1991); Arellano and Bover (1995); Blundell and Bond (2000), who refined the first-differenced GMM model. In this paper, we used the GMM system estimator. The static model can be reworked in the following dynamic representation:

$$
Y_{i t}=\gamma Y_{i t-1}+\beta_{0}+\beta_{1} X_{i t}+\mu_{1}+\varepsilon_{i t}
$$

If yit-1 is not fixed rather a random variable and $\operatorname{Cov}\left(Y_{i t-1, i}\right) \neq 0$ then estimator is not biased but also 
asymptomatically biased, this problem has a solution called endogeneity problem, all problems can be solved easily with the instrumental variables techniques. In case of exact equation, GMM and 2SLS method produce same or identical results. In case of over identified equation, two methods produce different result and GMM is considered to be superior, but unfortunately in case of un- identified equation both methods fail to work. In short, both 2SLS and GMM are basically instrumental variable techniques. Consider now, take the 1 lag in the equation. However, we solved the issue of endogeneity.

$$
Y_{i t}=\gamma Y_{i t-2}+\beta_{0}+\beta_{1} X_{i t}+\mu_{1}+\varepsilon_{i t-1}
$$

If we subtract equation 5 from equation 4 , Then,

$$
\Delta Y_{i t}=\beta_{0}+\beta_{1} \Delta X_{i t}+\gamma \Delta Y_{i t-1}+\Delta \varepsilon_{i t}
$$

In equation 6 endogeneity has been bypassed, however, equation 5 shows that $\operatorname{Cov}($ Yit-1, Eit-1) $\neg 0$.Now we can easily estimate the GMM equation at level form, or 1 difference form by using different instrument variables. Now,

$$
\Delta Y_{i t-1}=\beta_{0}+\beta_{1} \Delta X_{i t-1}+\gamma \Delta Y_{i t-2}+\Delta \varepsilon_{i t-1}
$$

If we add one more difference in equation 7 , Then

$$
\Delta Y_{i t-1}=\beta_{0} \Delta X_{i t-2}+\gamma \Delta Y_{i t-3}+\Delta \varepsilon_{i t-2}
$$

Now you can solve the problem of endogeneity easily with difference equation. We apply the GMM principle, when number of moment condition can exceed the number of unknown parameter. In this method, we also minimize the sum of squares of the moments is also known as GMM estimator.

\section{Data description and Sources}

The data collected for the period of 2002 to 2015 and compiled from various sources. All variables are used per annum except border, and distance data. Pakistan's bilateral trades from other trading partners' data were collected from UN COMTRADE statistics. The Secondary data were collected from world development indicators (WDI),CEPII and http://globalization.kof.ethz.ch/. A specific description of the variables is given in table 3.1.

In our study, we used border dummy that equals 1 if the Pakistan shares a border with trade partners and 0 otherwise. In short, cultural proximity is indexing of three variables (Number of Ikea (per capita) and McDonald's Restaurants, Trade in books) same as; political globalization is also index of four variables (Membership in International Organizations, Embassies in Country, International Treaties and Participation in U.N. Security Council Missions) and each variable has different weight in the index. Similarly, generate the dummy of SAARC member of SAARC is equal 1 , otherwise 0 . A specific Correlation matrix is presented in Table 3.2.

\section{Empirical Results}

Table 4.3: Pakistan's Trade and Gravity: GMM-System

\begin{tabular}{lccc}
\hline Dependent Variable & Export & Import & Bilateral Trade \\
\hline Variables & GMM & GMM & GMM \\
\hline D.L1 & $0.71^{* * *}$ & $0.618^{* * *}$ & $0.701^{* * *}$ \\
& $(0.067)$ & $(0.069)$ & $(0.065)$ \\
Ln GDP & \\
& $-0.617^{* *}$ & 0.33 & 0.0525 \\
Ln GDP & $(0.292)$ & $(0.304)$ & $(0.279)$ \\
& -0.105 & 0.0353 & -0.148 \\
Political & $(0.164)$ & $(0.148)$ & $(0.128)$ \\
& $0.040^{* * *}$ & 0.001 & 0.010 \\
cultural & $(0.007)$ & $(0.008)$ & $(0.006)$ \\
& 0.006 & $0.019^{* * *}$ & $0.012^{* * *}$ \\
distance & $(0.003)$ & $(0.005)$ & $(0.004)$ \\
& -0.0001 & -1.3605 & 2.1603 \\
border & $(7.25)$ & $(5.74)$ & $(5.27)$ \\
& 0.514 & -0.466 & 0.338 \\
SAARC & $(0.616)$ & $(0.602)$ & $(0.517)$ \\
& 0.784 & $0.859^{* *}$ & 0.543 \\
Constant & $(0.546)$ & $(0.428)$ & $(0.381)$ \\
& $8.308^{* * *}$ & -1.496 & 1.519 \\
Observations & $(1.477)$ & $(1.730)$ & $(1.663)$ \\
Wald chi ${ }^{2}$ & 143 & 143 & 143 \\
\hline Notes: Standard & $438.28^{* * *} 699.79^{* * *}$ & $710.02^{* * *}$ \\
p errors in parentheses, & $* * *$ & $p<0.01, * *$ \\
& & &
\end{tabular}

As a starting point, we used some time invariant variable in econometric gravity model, so fixed effects models suffer from a technical issue in the gravity model. However, it became statistically consistence, implying that random effects and Tobit and GMM model, because they all remove the econometric issues. The results of random effects are reported in Table 4.1.

There are three different types of models, one is export, second is import and third is the bilateral trade model which is mostly known as the trade volume. The random effect model performs well, explaining up to 50 per cent of sample variation in the Pakistan's bilateral trade. The size of economic results is consistent under the random effects, both coefficients are highly 
Table 3.1: Descriptive statistics of Selected Regions

\begin{tabular}{llcccc}
\hline Variables & Definition & Mean & S.D & Min & Max \\
\hline Export & Export flows come to the rest of the world(\$ Million) & 812.9 & 1,093 & 32 & 4,300 \\
Import & import flows come from the rest of the world(\$ Million) & 1,965 & 1,949 & 30 & 11,000 \\
Bilateral Trade & Bilateral trade between Pakistan and trade partners (\$ Milllion) & 2,778 & 2,479 & 209 & 12,900 \\
GDPi & GDP per capita, PPP (current international \$) & 8.291 & 0.161 & 7.975 & 8.519 \\
GDPk & GDP per capita, PPP (current international \$) & 9.926 & 1.28 & 6.797 & 11.41 \\
Cultural proximity & Index of three variables & 65.66 & 35.07 & 1 & 97.14 \\
Political globalization & Index of four variables & 71.42 & 16.28 & 37.25 & 93.71 \\
Distance & Geographical Distance & 3,050 & 3,283 & 0 & 11,092 \\
Border & Border share=1, otherwise=0 & 0.636 & 0.483 & 0 & 1 \\
SAARC & Member of SAARC=1, otherwise=0 & 0.182 & 0.387 & 0 & 1 \\
\hline
\end{tabular}

Source: Pakistan Bureau of Statistics

Table 3.2: Correlation Matrix

\begin{tabular}{lccccccc}
\hline & GDPi & GDP $_{k}$ & Political & Cultural & Distance & Border & SAARC \\
\hline GDPi & 1 & & & & & & \\
GDP $_{k}$ & 0.1388 & 1 & & & & & \\
Political & 0.1502 & 0.0336 & 1 & & & & \\
Cultural & 0.0448 & 0.7619 & 0.2327 & 1 & & & \\
Distance & -0.0189 & 0.5165 & 0.4388 & 0.5589 & 1 & & \\
Border & 0 & 0.8444 & 0.0115 & 0.8171 & 0.6848 & 1 & \\
SAARC & 0 & -0.8126 & -0.116 & -0.6584 & -0.4146 & -0.6236 & 1 \\
\hline
\end{tabular}

significant at $1 \%$ in Pakistan's bilateral trade and import model and local size of economic is not matter for export. This indicates that size of economic promotes bilateral trade and especially, import. Other supporting variables political globalization and distance both are significant but in case of Pakistan only geographical distance coefficient positive significant at $10 \%$ in first two cases and $5 \%$ significantly at the bilateral trade. The coefficient of the political globalization in random effect model is statistical significantly at $5 \%$ in gravity model. Similarly, the coefficient of cultural proximity, border share and SAARC is no importance for Pakistan's export, import, and bilateral trade model.

The results support the real facts in tobit regression model in table 4.2. As for the export models, the partner GDP raises the export of Pakistan among the partner countries, it determined the export of goods. Overall, this indicator has led to positive effects on Pakistan trade, showing up fairly positive effects on export, import and bilateral trade of the Pakistan's economy. Similarly, local GDP does not matter for the export, but significantly contributes to the import and even bilateral trade at $1 \%$. The results also show that all export, import, and bilateral trade are pay role of political factors; it is significant at 1 per cent in all cases. The distance also matters in bilateral trade; it determined the cost of transportation. When cost of transportation is high, the trade will go down. The cultural, SAARC and border share have insignificant effects in all dynamic model.

The next section will report the GMM results with first-differenced in table 4.3. The coefficients of export, import and bilateral trade are significant on own lag at $1 \%$.Another interesting finding is that coefficients of the size of economics of Pakistan is negatively significant at $5 \%$, but economic size of trade partners is insignificant in all cases. Similarly, trade partner GDP 
Table 4.1: Pakistan's trade and Gravity: Random Effects

\begin{tabular}{lccc}
\hline Dependent Variables & Export & Import & Bilateral Trade \\
\hline Variables & Random Effects & Random Effects & Random Effects \\
\hline Ln $G D P_{i}$ & -0.0301 & $1.596^{* * *}$ & $1.379^{* * *}$ \\
& $(0.366)$ & $(0.336)$ & $(0.317)$ \\
Ln GDP $P_{k}$ & $1.105^{* * *}$ & $0.553^{* * *}$ & $0.592^{* * *}$ \\
& $(0.205)$ & $(0.192)$ & $(0.180)$ \\
Political & $0.0333^{* * *}$ & $0.0349^{* * *}$ & $0.0276^{* * *}$ \\
& $(0.012)$ & $(0.010)$ & $(0.0105)$ \\
cultural & -0.004 & 0.0004 & -0.0009 \\
& $(0.005)$ & $(0.005)$ & $(0.005)$ \\
distance & $-0.0001^{*}$ & $-0.0001^{*}$ & $-0.0001^{* *}$ \\
& $(7.910)$ & $(6.750)$ & $(6.590)$ \\
border & -0.586 & 0.275 & 0.341 \\
& $(1.338)$ & $(0.844)$ & $(0.910)$ \\
SAARC & 2.391 & -0.063 & 0.964 \\
& $(1.553)$ & $(0.894)$ & $(1.005)$ \\
Constant & $7.242^{* * *}$ & $-13.98^{* * *}$ & $-11.68^{* * *}$ \\
& $(2.119)$ & $(1.838)$ & $(1.750)$ \\
$R^{2}$ & 0.48 & 0.54 & 0.62 \\
Observations & 154 & 154 & 154 \\
Country Effect & Yes & Yes & Yes \\
Year Effect & Yes & Yes & Yes \\
\hline
\end{tabular}

Notes: Standard errors in parentheses, ${ }^{* *} p<0.01,{ }^{* *} p<0.05,{ }^{*} p<0.1$ respectively.

Table 4.2: Pakistan's Trade and Gravity: Tobit Model

\begin{tabular}{lccc}
\hline Dependent Variable & Export & Import & Bilateral Trade \\
\hline Variables & Tobit Regression & Tobit Regression & Tobit Regression \\
\hline Ln GDP $i$ & -0.046 & $1.598^{* * * *}$ & $1.392^{* * * *}$ \\
& $(0.3590$ & $(0.32)$ & $(0.311)$ \\
Ln GDP & $1.112^{* * *}$ & $0.540^{* * *}$ & $0.585^{* * *}$ \\
& $(0.20)$ & $(0.184)$ & $(0.176)$ \\
Political & $0.033^{* * *}$ & $0.034^{* * *}$ & $0.027^{* * *}$ \\
& $(0.012)$ & $(0.009)$ & $(0.010)$ \\
cultural & -0.004 & 0.001 & -0.0007 \\
& $(0.005)$ & $(0.005)$ & $(0.004)$ \\
distance & $-0.0001^{* *}$ & $-0.0001^{* *}$ & $-0.0001^{* *}$ \\
& $(7.940)$ & $(6.380)$ & $(6.420)$ \\
border & -0.565 & 0.287 & 0.329 \\
& $(1.387)$ & $(0.722)$ & $(0.850)$ \\
SAARC & 2.407 & -0.051 & 0.954 \\
& $(1.622)$ & $(0.729)$ & $(0.927)$ \\
Constant & $7.282^{* * *}$ & $-13.89^{* * *}$ & $-11.70^{* * *}$ \\
& $(2.101)$ & $(1.766)$ & $(1.694)$ \\
Observations & 154 & 154 & 154 \\
sigma_u & $1.579^{* * *}$ & $0.648^{* * *}$ & $0.869^{* * *}$ \\
& $(0.349)$ & $(0.157)$ & $(0.195)$ \\
sigma_e & $0.383^{* * *}$ & $0.379^{* * *}$ & $0.345^{* * *}$ \\
& $(0.022)$ & $(0.022)$ & $(0.020)$ \\
Wald chi ${ }^{2}$ & $126.27^{* * *}$ & $247.53^{* * *}$ & $229.31^{* * *}$ \\
\hline
\end{tabular}

Notes: Standard errors in parentheses, ${ }^{* *} p<0.01,{ }^{* *} p<0.05,{ }^{*} p<0.1$

is no important in GMM results. Our export depends on the political globalization that will raise and fall through this channel, this factors is not much important in case of import and bilateral trade model. Our results also show that exports do not promote on the basis of cultural proximity coefficient, which is statistically insignificant, but interesting our imports also increase on the cultural proximity basis. The geographical distance and border share and partner economic size have insignificant effects in all dynamic model. Similarly, the 
coefficients of SAARC organization have significant effect during import model but not crucial for export and bilateral trade model.

\section{Conclusions}

The purpose of this paper was to analyze the determinants of Pakistan's bilateral trade flows to the major 11 trading partners by using a gravity model for the period of 2002 to 2015. We applied a tobit, and random effects for the analyses. In this research, we also use a dynamic panel (GMM estimator) to overcome the issues of correlation, time invariant variables, heteroskedasticity and endogeneity for some predictor variables (Baltagi, 2008). When we use Tobit, random effect, and GMM models, the economic size of Pakistan and trade partners have significant effect on Pakistan's export, import and bilateral trade, indicating that developed countries do indeed more trade then the under developed countries. The remaining variables were little bit affect. The results are according to the literature (Anderson, 2011; Batra, 2006; De, 2013; Faustino and Proença, 2011; Kabir and Salim, 2010; Leitao and Tripathi, 2013; Prehn et al., 2016; Ranajoy et al., 2006). The results conclude that local sizes of economy enhance export, import and bilateral trade; while international economic mass is important for Pakistan; trade decreases when distance between two partners increases. The estimated results are consistent with the theoretical models, Pakistan' trade partners with economic masses, political globalization, and distance have strong impact through trade.

\section{References}

Abiad, A., Mishra, P., and Topalova, P. (2014). How does trade evolve in the aftermath of financial crises? IMF Economic Review, 62(2):213-247.

Anaman, K. A. and Al-Kharusi, L. H. (2003). An analysis of trade flows between brunei darussalam and the european union. ASEAN Economic Bulletin, pages 60-72.

Anderson, J. E. (2011). The gravity model. Annu. Rev. Econ., 3(1):133-160.

Arellano, M. and Bond, S. (1991). Some tests of specification for panel data: Monte carlo evidence and an application to employment equations. The review of economic studies, 58(2):277-297.

Arellano, M. and Bover, O. (1995). Another look at the instrumental variable estimation of error-components models. Journal of econometrics, 68(1):29-51.

Babetskaia-Kukharchuk, O. and Maurel, M. (2003). Accession to the wto and eu enlargement: what potential for trade increase?
Baier, S. L. and Bergstrand, J. H. (2009). Bonus vetus ols: A simple method for approximating international trade-cost effects using the gravity equation. Journal of International Economics, 77(1):77-85.

Balassa, B. (1966). Tariff reductions and trade in manufacturers among the industrial countries. The American Economic Review, 56(3):466-473.

Baltagi, B. (2008). Econometric analysis of panel data. John Wiley \& Sons.

Baroncelli, E. (2007). The peace dividend,safta, and pakistanindia trade. The Challenges and Potential of Pakistan-India Trade, 59.

Batra, A. (2006). India's global trade potential: The gravity model approach. Global Economic Review, 35(3):327-361.

Blomqvist, P. (2004). The choice revolution: privatization of swedish welfare services in the 1990s. Social policy $\mathcal{E}$ administration, 38(2):139-155.

Blundell, R. and Bond, S. (2000). Gmm estimation with persistent panel data: an application to production functions. Econometric reviews, 19(3):321-340.

Bussière, M., Fidrmuc, J., and Schnatz, B. (2008). Eu enlargement and trade integration: Lessons from a gravity model. Review of Development Economics, 12(3):562-576.

Butt, W. A. et al. (2008). Pakistan's export potential: A gravity model analysis. Technical report, State Bank of Pakistan, Research Department.

Caves, R. E. (1981). Intra-industry trade and market structure in the industrial countries. Oxford Economic Papers, 33(2):203-223.

De, P. (2013). Assessing barriers to trade in services in india: An empirical investigation. Journal of Economic Integration, pages 108-143.

Eichengreen, B. and Irwin, D. A. (1998). The role of history in bilateral trade flows. In The regionalization of the world economy, pages 33-62. University of Chicago Press.

Faustino, H. C. and Proença, I. (2011). Effects of immigration on intra-industry trade: a logit analysis.

Kabir, M. and Salim, R. (2010). Can gravity model explain bimstec's trade? Journal of Economic Integration, pages 143165.

Khan, A. H. and Mahmood, Z. (2000). Pakistan and Emerging Global Trading Environment: Challenges and Opportunities. Vanguard.

Kong, Y. F. and Kneller, R. (2016). Measuring the impact of china's export growth on its asian neighbours. The World Economy, 39(2):195-220.

Leibenstein, H. (1966). Shaping the world economy: suggestions for an international economic policy.

Leitao, N. C. and Tripathi, S. (2013). Portuguese trade and european union: The gravity model. 
Minetti, R., Mulabdic, A., Ruta, M., and Zhu, S. (2018). Are banks engines of export? financial structures and export dynamics.

Montanari, I., Nelson, K., and Palme, J. (2008). Towards a european social model? trends in social insurance among eu countries 1980-2000. European Societies, 10(5):787-810.

Pöyhönen, P. (1963). A tentative model for the volume of trade between countries. Weltwirtschaftliches Archiv, pages 93-100.

Prehn, S., Brümmer, B., and Glauben, T. (2016). Gravity model estimation: fixed effects vs. random intercept poisson pseudo-maximum likelihood. Applied Economics Letters, 23(11):761-764.

Rahman, M., Shadat, W. B., Das, N. C., et al. (2006). Trade potential in safta: An application of augmented gravity model. CPD occasional paper series, 61:512.

Ranajoy, B., Banerjee, T., et al. (2006). Does the gravity model explain india direction of trade? a panel data approach. Technical report, Indian Institute of Management Ahmedabad, Research and Publication Department.

Rauch, J. E. (1999). Networks versus markets in international trade. Journal of international Economics, 48(1):7-35.

Samy, Y. and Dehejia, V. H. (2011). Trade and labor standards in the european union: A gravity model approach. The International Trade Journal, 25(5):581-618.

Serrano, R. 1. and Pinilla, V. (2012). The long-run decline in the share of agricultural and food products in international trade: a gravity equation approach to its causes. Applied Economics, 44(32):4199-4210.
Suvankulov, F. and Guc, Y. (2012). Who is trading well in central asia? a gravity analysis of exports from the regional powers to the region. Eurasian Journal of Business and Economics, 5(9):21-43.

Thornton, J. and Goglio, A. (2002). Regional bias and intraregional trade in southeast asia. Applied Economics Letters, 9(4):205-208.

Toh, K. (1982). A cross-section analysis of intra-industry trade in us manufacturing industries. Weltwirtschaftliches Archiv, 118(2):281-301.

Trotignon, J. (2010). Does regional integration promote the multilateralization of trade flows? a gravity model using panel data. Journal of Economic Integration, pages 223-251.

Tumbarello, P. (2006). Are regional trade agreements in asia stumbling or building blocks? some implications for the mekong countries. In seminar on Accelerating Development in the Mekong Regionthe Role of Economic Integration, Siem Reap, Cambodia, June, pages 26-27.

Ullah, M. S. and Inaba, K. (2012). Impact of rta and pta on bangladeshs export: application of a gravity model. Journal of Industry, Competition and Trade, 12(4):445-460.

Verbeek, M. (2004). A guide to modern econometrics (2nd [rev. and updated] ed.). chichester [etc.].

Westerlund, J. and Wilhelmsson, F. (2011). Estimating the gravity model without gravity using panel data. Applied Economics, 43(6):641-649.

Xuegang, C. (2008). Study on xinjiangs bilateral trade using a gravity model. Asia Europe Journal, 6(3-4):507-517. 


\title{
Impact of Infrastructure and Institutional Quality on Industrial Sector of Pakistan
}

\author{
Shehnaz ${ }^{* 1}$, Tayyaba Idrees ${ }^{2}$, \& Kaleem Anwar Mir ${ }^{3}$ \\ 1 ,2Fatima Jinnah women university Rawalpindi, Pakistan \\ ${ }^{3}$ Global Change Impact Studies Centre, Ministry of Climate Change, Islamabad, Pakistan
}

\begin{abstract}
The purpose of this study is to analyze the impact of infrastructure and institutional quality on industrial growth of Pakistan. The study covers the time span of 1984 2012. The ARDL (Auto Regressive Distributive Lag) is employed to see the combine and individual impact of infrastructure and institutional quality on industrial growth of Pakistan, respectively. Both infrastructure and institutional quality are measured through two distinct proxies. Infrastructure and institutional quality are found to be positively related to industrial growth. Based on the results of present study it is beneficial to make the institutions strong and invest more on infrastructure development.
\end{abstract}

\section{Introduction}

Infrastructure can be a vector of change in addressing some of the most systemic development challenges of today's world: social stability, rapid urbanization, climate change adaptation, mitigation and natural disasters. Without an infrastructure that supports green and inclusive growth, countries will not only find it harder to meet unmet basic needs, they will struggle to improve competitiveness. Today, the infrastructure gap in low and middle-income countries is estimated at US $\$ 1$ trillion. More and more, countries need to turn to the private sector as well as the public sector to build and operate their essential infrastructure.

Society comprises of different individuals, their goal is not only to maximize individual's welfare but of society as a whole. Welfare level can be calculated through analyzing quality of life an individual possess Aschauer (1990). Aspirations of economic development are major reason behind the expansion of infrastructure, as it ensures better quality of life. Without an infrastructure that scales up growth, countries will find it harder to meet unmet basic needs. Apart from that, they struggle to improve competitiveness Aschauer (1988). Providing infrastructure without the sound institutional framework will pose a threat to sustainable economic growth. Institutions are made by government, to shape the incentives for key economic actors of the society. Economies facing institutional bottlenecks fail to compete as in all its forms and shapes, it assists in shaping the performances of economic agents to attain sustainable economic growth; while the avail-

\footnotetext{
${ }^{1}$ Corresponding author.

Email: shehnaz@gmail.com
}

ability of infrastructure speeds up specialization process. In contemporary times, the institutional deficiencies and loopholes are the main reasons behind less growth promoting investments. To accelerate growth, overall or sectoral, the imperative need is to provide access to markets. Hence, both institutional quality and infrastructure have significant impact on industrial growth (Valeriani et al., 2011).

Many studies have been conducted in order to analyze the linear relationship between infrastructure and institutional quality (Esfahani and Ramirez, 2003; Mamatzakis, 1999; Okoh and Ebi, 2013). Whereas, the perspective of combine impact of infrastructure and institutional quality on industrial growth is yet unexplored. Since last two decades, Pakistan has been facing the deteriorating conditions of infrastructure. Imran and Niazi (2011) called the low quality of infrastructure a hindrance in achieving the sustainable growth of production sector in Pakistan. This low industrial growth slowed down the economic growth of Pakistan (Power, 1963). There is a set of theorists, who affirmed the role of institutions in shaping the pattern of economic development. They grounded and based their analysis on the development of industrial sector (Seidman, 1994). Since institutions play pivotal role in paving or restraining the way of economic growth; they may help the economy in fostering growth or prove to be a friction in the implementation of industrial policies. Keeping in view the importance of institutions and infrastructure, the present study will evaluate their combined impact on industrial growth. The hypothesis of the study is "The combined effect of infrastructure and in- 
stitutional quality on industrial growth is positive."

Present study adapted the framework of Okoh and Ebi (2013) to evaluate the long run combined impact of institutional quality and infrastructure on industrial growth of Pakistan. Based on the findings, few policy recommendations are stated.

The rest of the study is organized as follows. Section 2 makes a comprehensive theoretical and empirical appraisal of the existing literature. Section 3 contains the data description and methodology that explains the estimation technique. Section 4 presents the results and discussion while section 5 concludes the study.

\section{Literature Review}

Following section contains comprehensive theoretical and empirical appraisal of the existing literature; to analyze the impact infrastructure and institutional quality on industrial growth of Pakistan.

\subsection{Infrastructure and Industrial Growth}

The individual, as well as combined effect of infrastructure investment and institutional quality on economic growth, were examined by Okoh and Ebi (2013). The study ultimately presents three results. Increase in infrastructure investment is found to have positive relation with economic growth. Lower institutional quality renders economic growth. While, the combined effect of infrastructure investment and institutional quality on economic growth was nonsignificant. The above mentioned study makes it clear that the positive affect of infrastructure investment is dependent on institutional quality. The individual impact of infrastructure and institution on growth are examined in many studies, including Rodrik et al. (2004) and Chong and Calderon (2000).

Esfahani and Ramirez (2003) contributed in literature by evaluating contribution of institutions and infrastructure to GDPin a cross-country analysis. The study employed simultaneous equation model to avoid simultaneity problem. The study incorporates data of 75 countries for the time-period of 1965-1995. Telephone lines were used as proxy for infrastructure. The results showed that the contribution of infrastructure to GDP is substantial and the contribution overweighs the cost of provision of these services. The results suggest, apart from other factors, infrastructure is important for development. Mamatzakis (1999) while examining the impact of public infrastructure on Greek manufacturing sectors, finds out that improvement in infrastructure reduce the cost of production hence positive impact on productivity. It is clear from the study that cost elasticity is negative with respect to public infrastructure for most of the industries ${ }^{1}$. When investment in public infrastructure increases, the cost of production reduces; results in the increased efficiency and growth of industrial sector of Pakistan. There exist the evidences of both negative and positive relationship between infrastructure and industrial growth rate. Shah (1992) conducted a study for 26 Mexican manufacturing industries over the time span of 1970-1987. Gauss-Newton's method is used to evaluate the impact of investment in public sector infrastructure on performance of industrial sector. They imposed price homogeneity condition, which led to system of equation nonlinear in parameters. Therefore, an estimation technique, which is useful to remove heteroskedasticity, is employed. The reported study found out that public infrastructure is having very small and positive impact on industrial profitability. They also found that private sector responded more positively to direct/voluntary investment in public infrastructure as compared to involuntary/ indirect investment.

Démurger (2001) analyzed the relationship of infrastructure and growth for China. The researcher analyzed 24 provinces of China for the period of 19851998. According to development strategies, investment should be made considering the importance of that particular sector. From year 1960 onwards, there was emphasis on heavy industry development and provisional self-sufficiency since infrastructure improvement played pivotal role in market development; therefore, making it imperative to determine that underdeveloped infrastructure networks lead to growing regional disequilibrium in China. Simple growth model revealed different geographical location, infrastructure investment, and telecommunication facilities matter a lot for better performance of provinces.

Arnold et al. (2015) examined Indian manufacturing growth for the time span of 1993-2005 by using time series model. This study employed Ordinary Least Square (OLS) to test Cobb Douglas Production function. The study analyzed both policy changes and its implementations. Along with finding positive relationship between private sector participation and services in manufacture sector, the study found, development of infrastructure led to industrial growth. However, they analyzed just the impact of infrastructure on industrial growth regardless of institutions.

\subsection{Institutions and Industrial Growth}

Meyer and Sinani (2009) argued that institutional framework creates incentives and business practices, which in turn affect the nature of competition. Both foreign and domestic firms are encouraged to compete

\footnotetext{
${ }^{1}$ Cost of production has negative relation with availability of infrastructure. Investment in public infrastructure facilitates industrial transactions. Therefore, investment in public infrastructure will reduce cost of production in industries
} 
in an environment protected by market rules. Heckelman and Powell (2008) contributed to the existing literature presented previously by Leff (1964) and Huntington (1968). Leff (1964) and Huntington (1968) believed that corruption has positive impact on economic growth. They state that government's failure to implement pure and good rules provoke corruption, which in turn help economies to grow. However, Nawatmi et al. (2016) empirically tested this hypothesis. The reported study analyzed the relationship for 83 countries. Countries were categorized based on their economic freedom. Democracy is associated with the overall economic freedom index. Using independent variables including log initial GDP, investment, democracy, corruption, and a set of regional dummies. Following the footsteps of Clarke (1995) and Fölster and Henrekson (1999) this study employed Weighted Least Square (stocktickerWLS) to steer clear of the issue of heteroscedasticity. This study gave the results that benefit of corruption for growth increases with increasing level of democracy. Therefore, conclusion of the study is that positive or negative impacts of corruption depend on quality of institutions. The study suggested that when government fails to operate under laws and regulation, then corruption is the best way to increase growth.

While examining the impact of institution quality on industrial growth Grigorian and Martinez (1999) hypothesized that the marginal effect of institutional improvements on industrial growth will be stronger in transition economies. Redek and Sušjan (2005) tested this hypothesis later on and concluded there exists a strong negative relation between institutions and economic growth, in case of transitional economies. The institutional theory, recommended by North (1993) suggests that institutions set market rules, ensure interactions among economic actors confirmed that economic actions are binded by these rules.

\section{Data and Model Specification}

For empirical investigation of macro-economic variables, the data have been retrieved from secondary sources. The present study retrieved data from World Development Indicator (WDI), International Country Risk Guide (ICRG), and Economic Survey of Pakistan. The time series data are employed over time span of 1984- 2012. Non-availability of data for corruption, limits the timeperiod to 28 years.

However, length of roads and telephone lines are used as proxies for infrastructure. Length of roads and telephone lines were previously used as proxy for infrastructure by Loayza and Wada (2012). Data for length of roads are retrieved from Economic Survey of Pakistan; whereas, the data for telephone lines are retrieved from World Development Indicator (WDI).

To analyze impact of institutional quality on industrial sector of Pakistan, two proxies are used in the present study. First, Corruption and second is Contract Intensive Money Index (CIM). Previously these two indicators were used as proxy for institutional quality by Bassey et al. (2013), for Nigeria. Data for corruption are retrieved from International Country Risk Guide (ICRG). Contract intensive money index is calculated through following formula. The calculation of CIM is based on mathematical formula provided by Okoh and Ebi (2013).

$$
C I M=\frac{M_{2}-C_{0}}{M_{2}}
$$

While,

$$
\begin{aligned}
& M_{2}=\text { money and quasi money } \\
& C_{0}=\text { currency in circulation }
\end{aligned}
$$

The study used CIM as proxy of institutional quality that measures or gauges the enforceability and security of property rights.

Other than institutional quality and infrastructure, some other variables, which determine industrial growth, are added to avoid specification bias. Present study used trade openness, gross capital formation, real effective exchange rate and the variable of financial development as determinants of industrial sector ${ }^{2}$.

\subsection{Model and Methodology}

In order to empirically investigate the short and long run impact of infrastructure and institutional quality on the growth of industrial sector of Pakistan, present study employed Auto-Regressive Distributed Lag (ARDL) bound testing approach. It is proposed by Pesaran et al. (2001).

ARDL has an edge over other estimation techniques as it does not only provide estimates of short and long run components of the simultaneous model but it also removes the problems of exclusion bias and autocorrelation (Narayan, 2004).

Prior to all estimation unit root test will be applied, to determine the stationarity of the variables. The estimation started with conducting the bound test for the null hypothesis of no co-integration. The rejection and acceptance of null hypothesis was decided based on the value of F statistic described by (Pesaran et al., 2001)

\footnotetext{
${ }^{2}$ proxied as the money and quasi money

${ }^{3}$ If the F-statistics will be higher than the upper critical value, the null hypothesis of no long-run relationship will be rejected regardless of whether the underplaying order of integration of the variables is zero or one.
} 
${ }^{3}$. Following that criteria the estimation proceeded towards short run and long run estimations.

Estimation will be preceded using proxies for infrastructure and institutional growth as follow.

$$
\begin{aligned}
& I G_{t}=I N F_{t}+I N F_{t}^{2}+G C F_{t}+ \\
& T O_{t}+L R E E R_{t}+F D_{t}+\mu_{t} \quad \ldots \mathrm{A} \\
& I G_{t}=I N F_{t}+I N F_{t}^{2}+G C F_{t}+T O_{t} \ldots \mathrm{B} \\
& +L R E E R_{t}+F D_{t}+I N S T_{t}+\mu_{t}
\end{aligned}
$$

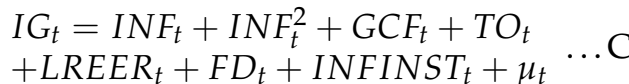

Whereas;

\section{' $t$ ' denotes the time period}

IG = Industrial growth

INF $=$ Infrastructure (Length of Roads and Telephone Lines)

INST = Institutional quality (Corruption and CIM)

$\mathrm{TO}=$ Trade openness

FD $=$ Financial Development (money and qusai money)

$\mathrm{GCF}=$ Gross capital formation $(\%$ of GDP)

REER= Real Effective Exchange Rate

$\mu_{1}=$ Error terms

After estimation of long run results, CUSUM (cumulative sum) test will be applied to check the stability of the model. To check the heteroskedasticity, BreuschPagan-Godfrey Test will be applied. Depending on probability value of BG test, the presence or absence of heteroscedasticity will be determined. To check normality of data, JarqueBera test will be applied. Probability value of JB test is expected to be higher than $10 \%$ so, null hypothesis of no skewness will be accepted.

\section{Results and Discussions}

Prior to analysis, the study investigates the order of integration for each variable included in estimation, through Augmented Dickey Fuller (ADF) test ${ }^{4}$. Results showed that there exists the (Pesaran et al., 2001) criteria $^{5}$. Therefore, the estimation can be proceede further. The second step for ARDL approach is to find appropriate lag length depending on which short run and long run relationship among the variables will be checked. In the next step the bound test is applied on each equation of the four models, with two proxies of infrastructure and institutional quality (refer to table 4.1)

\subsection{Diagnostic Tests}

Prior to long run results some diagnostic tests were applied (results given in Table 4.2 bellow). Serial correlation LM test is applied to check the correlation of variables with its past values. Breusch-Pagan-Godfrey test is applied to check the heteroscedasticity of the data. Stability of the model is assured by CUSUM (cumulative sum test), CUSUM square test and histogram normality test is applied ascertain that the normality assumptions are satisfied. In reference to table 4.4, depending on the p-value the null hypothesis of no hetero is accepted. It means that the data is homoscedastic. Histogram normality test shows that normality assumptions are truly satisfied. The null hypothesis of no skew in the data is accepted.

CUSUM recursive residual test and CUSUM square test are applied to check the stability of the model. It is clear that both the models are stable at $5 \%$ significance.

\subsection{Results of Long Run}

The results show that all the variables are significantly effecting industrial growth except contract intensive money index and trade openness.

In reference to Table 4.3, Length of roads is positively associated with industrial growth and it has a significant impact on industrial growth of Pakistan. It is estimated that $1 \%$ increase in length of roads will improve the industrial growth by $11 \%$. In the next equation, a proxy for institutional quality (corruption) is added. It is shown that in presence of corruption, $1 \%$ increase in length of roads will increase industrial growth by $5 \%$. Comparing the results with the previous equation, it is clear that the impact of change in length of roads is less. The industrial growth of Pakistan is associated negatively to quality of institutions. According to corruption index, provided by Thompson and Shah (2005), the higher value of corruption index refers to clean institutions. Hence, the results can be interpreted as 1 unit increase in corruption will increase the industrial growth by $0.04 \%$. In the next step, the estimation was carried with CIM. . The results show that CIM is associated positively with industrial growth. While, the coefficient of length of roads can be interpreted as, in presence of low contract enforceability, $1 \%$ change in length of roads will increase the industrial growth by almost 15\%. Furthermore, the result shows that the coefficient of combine impact of

\footnotetext{
${ }^{4}$ For results check appendix

${ }^{5}$ co-integration level of all variables must be a combination of level and first difference
} 
Table 4.1:

\begin{tabular}{lcccc}
\hline Equation & f-statistics & Significance & \multicolumn{2}{c}{ Critical bounds } \\
\hline Lrds & & & 0 bound & 1 bound \\
Lrds + corr & $3.74^{* *}$ & $5 \%$ & 3.15 & 4.43 \\
Lrds + lcords & $12.00^{* * *}$ & $1 \%$ & 2.96 & 4.26 \\
Lrds + cim & $9.55^{* * *}$ & $1 \%$ & 2.96 & 4.26 \\
Lrds + lcmrd & $3.55^{* *}$ & $5 \%$ & 2.96 & 4.26 \\
Ltelp & $3.54^{* *}$ & $5 \%$ & 2.96 & 4.26 \\
Ltelp + corr & $3.56^{*}$ & $10 \%$ & 3.15 & 4.43 \\
Ltelp + lcotelp & $6.26^{* * *}$ & $1 \%$ & 2.96 & 4.26 \\
Ltelp + cim & $4.61^{* * *}$ & $1 \%$ & 2.96 & 4.26 \\
Ltelp + lcmtelp & $15.66^{* * *}$ & $5 \%$ & 2.96 & 4.26 \\
\hline
\end{tabular}

Note: ${ }^{*}=10 \%$ significance, ${ }^{* *}=5 \%$ significance, ${ }^{* * *}=1 \%$ significance.

Table 4.2:

\begin{tabular}{lccc}
\hline Variables & Normality Test & Serial Correlation & Test for Heteroscedasticity \\
\hline Equ 1 & $0.386(0.82)$ & $2.99(0.087)$ & $1.34(0.29)$ \\
Equ 2 & $0.50(0.77)$ & $1.74(0.314)$ & $1.23(0.44)$ \\
Equ 3 & $2.49(0.28)$ & $2.76(0.17)$ & $0.81(0.66)$ \\
Equ 4 & $0.74(0.68)$ & $3.51(0.08)$ & $2.03(0.098)$ \\
Equ 5 & $0.70(0.70)$ & $4.57(0.122)$ & $1.67(0.29)$ \\
Equ 6 & $0.58(0.74)$ & $4.22(0.03)$ & $2.95(0.02)$ \\
Equ 7 & $0.13(0.93)$ & $3.6(0.10)$ & $1.61(0.26)$ \\
Equ 8 & $3.23(0.19)$ & $10.4(0.04)$ & $1.11(0.49)$ \\
Equ 9 & $0.18(0.91)$ & $7.00(0.07)$ & $0.67(0.76)$ \\
Equ 10 & $0.039(0.98)$ & $11.04(0.04)$ & $0.62(0.79)$ \\
\hline
\end{tabular}

Table 4.3:

\begin{tabular}{lccccc}
\hline Variables & Equ1 & Equ 2 & Equ 3 & Equ 4 & Equ 5 \\
\hline Lrds & $11.59^{* *}(2.01)$ & $13.1^{* * *}(4.17)$ & $19.71^{* * *}(3.36)$ & $15.85^{*}(1.79)$ & $15.91^{*}(1.79)$ \\
lrds $^{2}$ & $-0.49^{* *}(-2.05)$ & $-0.54^{* * *}(-4.27)$ & $-0.82^{* * *}(-3.41)$ & $0.66^{*}(-1.81)$ & $0.67^{*}(-1.81)$ \\
To & $-0.00-1.14$ & $-0.00^{* *}(-2.22)$ & $0.003(0.66)$ & $0.004(-1.25)$ & $0.004(-1.25)$ \\
Gcf & $-0.02^{*}(-1.78)$ & $-0.01^{* *}(-2.49)$ & $-0.04^{* * *}(-3.15)$ & $-0.02^{* *}(-2.01)$ & $-0.02^{*}(-1.64)$ \\
log(reer) & $-1.25^{* *}(-2.24)$ & $-0.26(-1.14)$ & $-1.20^{* *}(-2.49)$ & $-1.25^{* *}(-2.01)$ & $-1.25^{* *}(-2.00)$ \\
M2 & $0.008^{* * *}(2.75)$ & $0.00^{* * *}(4.87)$ & $0.005^{* * *}(3.74)$ & $0.008^{* * *}(2.54)$ & $0.008^{* *}(2.52)$ \\
Corr & - & $-0.06^{* * *}(-3.16)$ & - & - & - \\
Cim & - & - & - & $0.030(0.471)$ & - \\
Lcords & - & - & $-0.13^{*}(1.89)$ & - & - \\
Lcmrd & - & - & - & - & $0.002(0.48)$ \\
\hline
\end{tabular}

Note: ${ }^{*}=10 \%$ significance, ${ }^{* *}=5 \%$ significance, ${ }^{* * *}=1 \%$ significance.

length of roads and corruption is negatively related to industrial growth. The result can be interpreted as $1 \%$ combined increase in length of roads and corruption index (reduction in corruption) will reduce the industrial growth by $0.13 \%$.

Table 4.4 shows that the coefficient of telephone lines is related positively to industrial growth. How- ever, the isolated impact of telephone lines on industrial growth is nonsignificant. In second equation, in presence of corruption, the coefficient of telephone line is associated positively to industrial growth.

The result of the present study can be explained as in presence of corruption in the economy, $1 \%$ increase in telephone line will improve performance of indus- 
Table 4.4:

\begin{tabular}{lccccc}
\hline variables/equation & Equ 6 & Equ 7 & Equ 8 & Equ 9 & Equ 10 \\
\hline Ltelp & $0.27(1.11)$ & $0.83^{* * *}(3.24)$ & $1.84^{* * *}(15.38)$ & $0.81^{* * *}(4.02)$ & $0.60^{* *}(2.31)$ \\
ltelp & $0.01(-1.42)$ & $-0.030^{* * *}(-3.52)$ & $-0.08^{* * *}(-15.06)$ & $-0.02^{* * *}(-4.4)$ & $-0.02^{* *}(-2.50)$ \\
To & $0.001(0.90)$ & $0.008^{* *}(2.37)$ & $0.63^{* * *}(4.28)$ & $-0.03(-0.36)$ & $-0.002(-1.57)$ \\
Gcf & $0.016^{* * *}(-3.30)$ & $-0.027^{* * *}(-4.41)$ & $-0.03^{* * *}(-14.0)$ & $-0.02^{* *}(-2.65)$ & $-0.03^{* * *}(-4.69)$ \\
log(reer) & $-0.46^{* *}(-2.89)$ & $-0.29^{* *}(-1.41)$ & $-0.06(-0.89)$ & $-0.12(-0.55)$ & $-0.45^{* *}(-2.91)$ \\
M2 & $0.005^{* * *}(4.03)$ & $0.004^{* * *}(5.32)$ & $0.005^{* * *}(8.14)$ & $0.008^{* * *}(8.75)$ & $0.008^{* * *}(7.63)$ \\
Corr & & $-0.05^{* * *}(-3.12)$ & - & - & - \\
Cim & - & - & - & $-0.002(1.35)$ & - \\
Lcotelp & - & - & $-0.49^{* * *}(-3.48)$ & - & - \\
Lcmtelp & - & - & - & - & $0.001(0.32)$ \\
\hline
\end{tabular}

Note: ${ }^{*}=10 \%$ significance, ${ }^{* *}=5 \%$ significance, ${ }^{* * *}=1 \%$ significance.

tries by $0.8 \%$. The third equation result shows that combined impact of telephone lines and corruption is negatively associated to industrial growth. The coefficient can be interpreted as 1 unit combined change will effect industrial growth by $0.1 \%$, inversely. Furthermore, the estimation is preceded by using an alternative proxy of institutional quality that is CIM. Results can be interpreted as, in presence of low contract enforceability, $1 \%$ increase telephone lines will improve industrial growth by $0.6 \%$. The coefficient of CIM shows that CIM is not effecting industrial growth significantly. The interaction term of CIM and telephone is also not significant.

The study has used a quadratic term of both proxies of infrastructure to show the rate at which infrastructure is effecting industrial growth. The results show that similar to findings of Mesike et al. (2010), infrastructure is affecting the industrial growth positively. Industrial growth will increase but at a decreasing rate.

\section{Conclusion and Policy Recom- mendations}

Contribution of industrial growth is an important drive for economic growth of Pakistan. Unfortunately, industrial sector of Pakistan has not been showing a considerable progress, since last two decades. Many researchers, including Ilyas et al. (2010) and Kemal (2006) evaluated the reasons behind under development of industrial growth of Pakistan. According to Imran and Niazi (2011), the reason behind underdevelopment of industrial sector of Pakistan is presence of low quality of infrastructure. According to Méon and Sekkat (2005), institutions are of great importance for industrial sector. They stated that corruption does not hinder the industrial growth rather it makes the transaction easier. Hence, corruption acts as greasing the wheel.

The objective of the study is not only to scrutinize the impact of infrastructure and institutional quality, individually on industrial growth of Pakistan but also the combined impact of infrastructure and institutional quality on industrial growth of Pakistan. The study has touched the unexplored dimension. Therefore, two different proxies for infrastructure and institutional quality are used in every equation. For robust results, every equation is estimated twice, with variables of trade openness, gross capital formation, financial development, and real effective exchange rate.

The results of the present study reject the stated hypothesis. The results show that the combined impact of infrastructure and institutional quality on industrial growth of Pakistan is negative. The infrastructure is related positively to industrial growth. However the quadratic term of infrastructure shows that in relation to infrastructure, industrial growth is increasing but at a decreasing rate. However the weak institutional quality affects the industrial growth positively. A country with weak institutions can face a negative impact of capital formation.

Summarizing the whole study, it can be concluded that better infrastructure and weak institutions affect the industrial growth positively. However, the combined impact of infrastructure and institutional quality on industrial growth is negative.

Keeping in view results of the present study, to achieve considerable and long run industrial growth, following policy recommendations are suggested.

Since infrastructure is affecting industrial growth positively, investment should be made to infrastructure. However, investment in infrastructure should not be at cost of current expenditures; as compensation on current expenditures can deteriorate the industrial growth.

On one hand, weak institutions are promoting industrial growth. On the other hand, presence of corruption hindered the positive impact of gross capital formation. Hence, institutions should be made strong so that pure transactions could be insured. With reference to positive impact of financial development, a little incentive inform of inflation should be provided 
to investors. Increase in inflation should be at decreasing rate. Hence more and more investors will invest to private sector and industrial sector will grow at considerable rate. Anti-corruption laws should be applied strongly, so that illegal industrial activities could be removed. In case of violation of laws, punishment should be same for all.

\section{References}

Arnold, J. M., Javorcik, B., Lipscomb, M., and Mattoo, A. (2015). Services reform and manufacturing performance: Evidence from india. The Economic Journal, 126(590):1-39.

Aschauer, D. A. (1988). The equilibrium approach to fiscal policy. Journal of Money, Credit and Banking, 20(1):41-62.

Aschauer, D. A. (1990). Why is infrastructure. Industry Week.

Bassey, E., Sunday, O., and Okon, E. (2013). The impact of environmental accounting and reporting on organizational performance of selected oil and gas companies in the niger delta region of nigeria. Research Journal of Finance and Accounting, 4(3):57-73.

Chong, A. and Calderon, C. (2000). Causality and feedback between institutional measures and economic growth. Economics $\mathcal{E}$ Politics, 12(1):69-81.

Clarke, G. R. (1995). More evidence on income distribution and growth. Journal of development Economics, 47(2):403427.

Démurger, S. (2001). Infrastructure development and economic growth: an explanation for regional disparities in china? Journal of Comparative economics, 29(1):95-117.

Esfahani, H. S. and Ramirez, M. T. (2003). Institutions, infrastructure, and economic growth. Journal of development Economics, 70(2):443-477.

Fölster, S. and Henrekson, M. (1999). Growth and the public sector: a critique of the critics. European Journal of Political Economy, 15(2):337-358.

Grigorian, D. A. and Martinez, A. (1999). Industrial growth and the quality of institutions: what do (transition) economies have to gain from the rule of law? The World Bank.

Ilyas, M., Ahmad, H. K., Afzal, M., and Mahmood, T. (2010). Determinants of manufacturing value added in pakistan: An application of bounds testing approach to cointegration. Pakistan Economic and Social Review, pages 209-223.

Imran, M. and Niazi, J. (2011). Infrastructure and growth. The Pakistan Development Review, pages 355-364.

Kemal, A. R. (2006). Key issues in industrial growth in pakistan. Lahore Journal of Economics, 11.

Loayza, N. and Wada, T. (2012). Public infrastructure trends and gaps in pakistan.
Mamatzakis, E. (1999). Public infrastructure, private input demand, and economic performance of the greek industry.

Méon, P.-G. and Sekkat, K. (2005). Does corruption grease or sand the wheels of growth? Public choice, 122(1-2):69-97.

Mesike, C., Okoh, R., Inoni, O., et al. (2010). Supply response of rubber farmers in nigeria: an application of vector error correction model. Agricultural Journal, 5(3):146-150.

Meyer, K. E. and Sinani, E. (2009). When and where does foreign direct investment generate positive spillovers? a meta-analysis. Journal of International Business Studies, 40(7):1075-1094.

Narayan, P. K. (2004). Fiji's tourism demand: the ardl approach to cointegration. Tourism Economics, 10(2):193-206.

Nawatmi, S., Nusantara, A., and Isnowati, S. (2016). The relationship of corruption and economic growth. Proceeding ICOBAME.

North, D. C. (1993). Institutions and credible commitment. Journal of Institutional and Theoretical Economics (JITE)/Zeitschrift für die gesamte Staatswissenschaft, pages 11-23.

Okoh, A. S. and Ebi, B. O. (2013). Infrastructure investment, institutional quality, and economic growth in nigeria: An interactive approach. European Journal of Humanities and Social Sciences, 26(1).

Pesaran, M. H., Shin, Y., and Smith, R. J. (2001). Bounds testing approaches to the analysis of level relationships. Journal of applied econometrics, 16(3):289-326.

Power, J. H. (1963). Industrialization in pakistan: A case of frustrated take-off? The Pakistan Development Review, 3(2):191-207.

Redek, T. and Sušjan, A. (2005). The impact of institutions on economic growth: the case of transition economies. Journal of Economic Issues, 39(4):995-1027.

Rodrik, D., Subramanian, A., and Trebbi, F. (2004). Institutions rule: the primacy of institutions over geography and integration in economic development. Journal of economic growth, 9(2):131-165.

Seidman, G. W. (1994). Manufacturing militance: workers' movements in Brazil and South Africa, 1970-1985. Univ of California Press.

Shah, A. (1992). Dynamics of public infrastructure, industrial productivity and profitability. The review of economics and statistics, pages $28-36$.

Thompson, T. and Shah, A. (2005). Transparency internationals corruption perceptions index: Whose perceptions are they anyway. Retrieved May, 14:2013.

Valeriani, E., Peluso, S., et al. (2011). The impact of institutional quality on economic growth and development: An empirical study. Journal of Knowledge Management, Economics and Information Technology, 1(6):1-25. 


\title{
Impact of Self Expressive Brands and Brand Attachment on Brand Advocacy: The Mediating Role of Brand Love
}

\author{
Abdul Qayyum ${ }^{1}$, Ayesha Saeed ${ }^{2}$, \\ 1,2Riphah International University, Islamabad, Pakistan
}

\begin{abstract}
The main objective of this study was to examine the impact of self expressive brands and brand attachment on brand advocacy with the mediating role of brand love. Findings are revealed on the survey of people who get involved with the Clothing Brand and become brand advocates. Hypotheses were tested with a sample of 275 respondents and the regression analysis was conducted to test the hypotheses. The results of the study show the partial mediating impact of brand love on the relationship between self expressive brands and brand advocacy, while full mediation impact of brand love on brand attachment and brand advocacy relationship has been observed. This research project highlights that brand love needs to be created along with brand attachment in customers mind so as to make them brand advocates. The findings of this research will help the marketer for implementing better marketing techniques to make their brand more strong and recognizable among customers.

Key words: Self Expressive Brands, Brand Attachment, Brand Love, Brand Advocacy, Clothing Brand
\end{abstract}

\section{Introduction}

In the recent years, the marketers came to realize that the customer's experience, feedback and reviews are significant determinants for developing marketing strategies (Chattopadhyay and Laborie, 2005). So, they push the customers towards WOM behavior through direct interaction with customers (Wragg, 2004). During the past few decades, the researchers started paying attention to the concept of love (Hatfield and Sprecher, 1986). Because of the familiar and favorable signal that a brand sends, consumers buy the brand with more comfort, believing that the brand will meet their expectations (Kim et al., 2008). The consumers show greater love and attachment for brands that reflect their inner self as well as their social self (Carroll and Ahuvia, 2006). Consequently, their purchase decisions are mainly based on the symbolic meanings of a product, which is used to create and maintain self identity (Fournier, 1998). Such type of brand identification with oneself helps in creating positive feeling towards a specific brand called brand love (Hwang and Kandampully, 2012). For a brand love, the consumers are required to be attached to that brand so as to feel that if that brand is missed or matchless, they don't have the same brand (Hazen and Shaver, 1987). The concept of attachment was first taken from the attachment theory of psychology. Later on different authors have studied this with diverse perspectives as interpersonal relationships (Bowlby, 2012). According to Bergkvist and

\footnotetext{
${ }^{1}$ Corresponding author.

Email: abdul.qayyum@riphah.edu.pk
}

Bech-Larsen (2010), the consumers who have strong brand identification experience have more brand love and active engagement. People give positive comments about a brand and sometimes recommend it to others; it is asserted that brand advocates are also likely to accept new brand extensions and to forgive a brand for wrongdoing (Du et al., 2007).

Nowadays, consumers are facing uncertainty about brand attributes because of too much clutter of brands in the competitive market environment (Cătălin and Andreea, 2014). By choosing a specific brand, an individual may obtain personal identity as well as social identity in the society (Fournier, 1998). During the past few decades, only few researchers have examined the relationship of brand advocacy and brand choice. The previous research revealed that the higher level of brand advocacy enhances the chances of brand to be included in consideration set (Erdem and Swait, 2001). This research study extends previous work on brand advocacy and it will provide a good insight into the application of branding theory through consumerobject relationships. Furthermore, managerial implications for developing effective brand management system that appeal to customers will also be highlighted in this study (Sheeraz et al., 2012).

Creating the customer engagement is considered as an important business practice for establishing sustainable competitive advantage, so as to predict the future business performance (Brodie et al., 2013). The concept helps the firm in maintaining long term consumer- 
brand relationships, which states that customers form relationship with the brands which they like the most (Fournier, 1998). The customer engagement is desired by the marketers because it leads to sales growth and also enhances the firm's profitability (Sashi, 2012). The marketers should position the brands according to the consumer's preference and lifestyle (Cătălin and Andreea, 2014). The results of the study are beneficial for brand managers as they can use different marketing tools to make their brand more strong and recognizable for increased profits (Sheeraz et al., 2012).

This study has considerable importance from managerial aspect as it would indicate that if brand love influences the customer's perception towards a certain brand in a positive way and affect their purchase intension through the effect of positive word of mouth, then the firm should create the feeling of love by communicating the right message about the brand that is relevant to customers' identity and encourage them to "express yourself" through association with the brand (Hwang and Kandampully, 2012). Furthermore, the aim of the study is to add more knowledge to the existing literature on brand advocacy specifically in clothing industry.

\section{Literature Review}

\subsection{Brand Advocacy}

During the past few decades, the academic society and practitioners have started paying attention to the concept of brand advocacy. The customers consider advocacy as an influential source of information, because it is derived from a less biased source (Herr et al., 1991). When a customer makes connection with a particular brand, the connection leads him to advocacy as the customer willingly spreads positive WOM about the brand (Anderson, 1998). Du et al. (2007) defined the brand advocacy as "to accept new brand extensions and to forgive a brand for wrongdoing". According to Harrison-Walker (2001) the customer's commitment with a brand and the quality of service motivates the customers to advocate the brand among others. Brand advocacy is one form of value creation. The two dimensions of brand advocacy are words of mouth and brand acceptance (Wallace et al., 2014). Words of Mouth advocacy is considered as an important tool for brand development. It can be defined as the process of sharing information and opinions about a particular product or service among customers (Jalilvand et al., 2011). Words of mouth are created from friends, relatives, professionals and experts, etc (Senecal and Nantel, 2004). Whenever the company introduces new product, the customers accept the brand, recommend this to others and forget the wrongdoing of brand (Du et al., 2007).

\subsection{Self Expressive Brands and Brand Ad- vocacy}

Self expressive brand refers to a perception that how well a particular brand will communicate the person's inner self and boost his/her social self. By obtaining a specific brand, people tend to express to others what kind of personality they have (Georgescu et al., 2011). An individual present his/her likeable image through a specific brand. For example, a young girl may wear branded dress as to show that she is cool and stylish (Aaker, 2010). Self expressive brands persuade the consumer to accept the brand, develop bond of affection, become loyal and spread positive WOM about the brand (Carroll and Ahuvia, 2006). As self expressive brands have the ability to express customer's inner self, as well as social self among others therefore, the brand must have a clear and distinguish image that allow customers to show their personal identity to others (Karjaluoto et al., 2016).

Many research studies have been conducted to investigate the impact of brand advocacy on consumer behavior. When a consumer receives consistent positive WOM about a brand, then he or she shows stronger intention to purchase that brand (Mazzarol et al., 2007). Wallace et al. (2014) investigated the impact of selfexpressive brands on brand advocacy and stated that the customers like the brand that expresses their social selves to others and have high probability to accept new product from the same brand and forget the wrongdoing. The consumer develops strong bond and connectedness with a particular brand and tries to maintain long lasting relationship with the brand by spreading positive words of mouth about the brand and accepting its wrongdoing. Because the brand develops symbolic significance to consumer and become part of his personal identity, self image, and self esteem. The relationship leads the customers to brand advocacy (Rageh Ismail and Spinelli, 2012). So it can be hypothesized that:

$H_{1}$ : Self-Expressive Brands have positive impact on Brand Advocacy.

\subsection{Brand Attachment and Brand Advocacy}

In recent years, the brand attachment gained the importance in marketing. Attachment is the set of emotional and cognitive schemas that are used by consumers to create a relationship to connect themselves with the brand (Thomson et al., 2005). According to Batra et al. (2012) attachment is an emotional connection between a person and a brand. In attachment process, the consumers feel attachment to a particular brand, think that the brand is matchless, and miss the brand when the brand is not available to them (Park et al., 2006). Brand attachment creates emotional asso- 
ciation with a brand. This emotional attachment can be strengthened by three factors i.e., customer's association with a brand, affection with a brand and a feeling of strong liking towards a brand (Thomson et al., 2005). The attachment feelings that a consumers develop for a particular brand are the same as they develop attachment in their interpersonal relationships (Baldwin et al., 1996). Consumer with strong attachment to a brand is more willing to maintain long term relationship with the brand and produce positive word of mouth about the brand (Whan Park et al., 2010).

The concept of attachment was first taken from the attachment theory of psychology (Bowlby, 2012). This theory explained the deep attachment formed by the infants with caregivers. When this theory is applied to consumer brand relationship, the attachment to a brand is based on trust and consistency of response. The customer feels attachment to a brand, which is consistent and always available, maintain relationship with that brand and become brand advocate. For instance, a consumer decides to wear Hollister Brand because she feels emotional attachment with that brand. This feeling of attachment describes a strong bond of affection between the consumer and the brand (Kleine et al., 1995). After using that brand she will produce positive statements and spread positive Word of Mouth about the brand in her social circle. Hence, the customer's perception of attachment with a particular brand promotes the advocacy of that brand (Lee and Workman, 2015). Therefore, it is expected that:

$\mathrm{H}_{2}$ : Brand Attachment has positive impact on Brand Advocacy.

\subsection{Self Expressive Brands and Brand Love}

Ahuvia (2005) identified that the self expressive brands help to extend ones' 'self '. When a brand provides something imperative to a customer, they make this brand as part of their identity and include it in their social life (Goldsmith, 2009). Because the consumers are now aware that the brand is not only linked with their lifestyle, goals and values but also it is used to express those values to other people (Berger and Heath, 2007). The favorable characteristic of a brand helps in creating customer's self-connection and therefore leads to intense love and commitment to the brand that keeps the consumer with the brand and encourages him to become a brand lover (Loureiro et al., 2012). Based on cognitive perception, males are more loyal with a brand than females; as men require detailed information about a particular brand or product because of its technicality. So the company should provide specific information about the brand to its customers (Pandir and Yasin, 2017).

Fournier and Mick (1999) identified brand love as a sort of satisfaction and explained that a satisfied cus- tomer becomes emotionally attached to a brand and thus willingly declares love to that brand because the brand is incorporated in his/her identity. According to Aaker (2010) self-expressive brands develop a strong relationship between consumer and the brand. Aggarwal (2004) proposed that consumer makes relationship with brands as they consider them as relationship partners so they show stronger feeling of love and affection for that brand, which gives social identity and self confidence to them and hence this feeling of self confidence motivates them to show stronger love and affection towards that brand (Carroll and Ahuvia, 2006). So it is hypothesized that:

$\mathrm{H}_{3}$ : Self Expressive Brands have positive impact on Brand Love.

\subsection{Brand Attachment and Brand Love}

Many researchers have widely accepted that attachment is the element of brand love (Loureiro et al., 2012). According to Lee and Workman (2015) brand attachment develops strong brand loyalty among customers. The brand attachment creates feeling of love to a brand, helps to develop interest and to maintain the relationship with the brand in future. A consumer develops strong affective and cognitive perception of brand in his mind, which creates feelings of attachment with the brand Fournier (1998). There is a positive impact of brand attachment on brand love feeling. This feeling motivates the consumers to strengthen the trust on the brand as the interest in the brand leads to maintain long term relationship and develop feelings of love for that brand (Loureiro et al., 2012).

The emotional attachment develop strong relationship between customer and the brand, develops positive feeling for the brand and thus leads to brand love (Loureiro et al., 2012). The researchers had found that the psychological attachment to a brand encourages a customer to show willingness to obtain the brand. A consumer who is emotionally attached to a brand feels love towards with the brand, shows repeat purchase intention, spends resources (e.g., money, time and efforts) to obtain that brand and hence leading to brand loyalty (Lee and Workman, 2015). The attachment can be formed on the basis of relationship between an individual and a brand. For instance, the customers form attachment with luxury brands as the brands help the customers to enhance their classic image (Park et al., 2006). The consumer with positive experience of a brand feels strong emotional attachment to that brand and that emotional attachment leads to brand love (Carroll and Ahuvia, 2006). It is hypothesized that:

$\mathrm{H}_{4}$ : Brand Attachment has a positive impact on Brand Love. 


\subsection{Brand Love and Brand Advocacy}

According to (Fournier, 1998) love is a core element between consumer-brand relationships. The feeling of love may occur when a consumer possessed love towards a particular brand (Aaker, 1997). The relationship of brand love is deep, long lasting and is considered as irreplaceable (Albert and Merunka, 2013). Brand love motivates the customer to produce positive Words of Mouth about the brand (Batra et al., 2012). According to Pandir and Yasin (2017), if customer buys a brand at least once in two weeks, the feeling of love will be stronger. So, the loyal customers have higher probability to spread positive Words of Mouth (Bowman and Narayandas, 2001). Because the customers feel love towards the brand that they consider relevant with their inner self and social self (Cătălin and Andreea, 2014) and thus, brand love encourages the customers to spread positive words of mouth about the brand. So the customers produce positive views about the brand and maintain long lasting relationship with it (Albert and Merunka, 2013).

During the past few decades, different researchers have identified different love styles (Albert et al., 2008). Carroll and Ahuvia (2006) found the positive impact of brand love on word of mouth behaviour. When the satisfaction level of customer increases by experiencing a brand, s/he may spread positive opinion about the brand (Anderson, 1998). Brand passion is positively associated with evangelism, where people produce positive WOM about the brand and persuade others to make association with the same brand (Matzler et al., 2007). Biçakcioğlu et al. (2018) revealed that brand love is a powerful source of word of mouth communication, which states that stronger feeling of love encourage customers to spread positive words of mouth about a brand among their family, friends etc. So it is expected that:

$H_{5}$ : Brand Love has a positive impact on Brand Advocacy.

\subsection{Mediating role of Brand Love}

Carroll and Ahuvia (2006) stated that the brands which are more likely to enhance customer's identity have stronger affecting responses and hence create brand advocacy. When the people get involved with the brand, they feel love towards that brand, become brand advocates and produce positive word of mouth about the brand (Wragg, 2004). An individual may develop strong connection with the brand so to satisfy his/her psychological needs, to show identity and to make connection with others (Wallendorf and Arnould, 1988). Although the concept of eWOM is growing day by day, but the consumers consider traditional word of mouth more secure and safe for sharing their views about the product (Karjaluoto et al., 2016). The WOM behavior is affected by the nature of selfexpressive brand. If the brand is more self-expressive, the consumer will strongly engage in positive words of mouth. Because people want to make connection with brands so to feel sense of love for them. So, when a brand meets with both the actual and desired integration level of customer and enhances his or her sense of self, the person feels love for that brand and becomes brand advocate (Carroll \& Ahuvia, 2006).

According to Bergkvist and Bech-Larsen (2010) customers who have a stronger bond of affection with the brand express more brand love, and produce positive WOM about the brand (Wragg, 2004). The attachment shows the behavioral intention of the customer that how a customer responses to a specific brand. So, a customer with strong brand attachment will use emotional, cognitive and financial resources to obtain that brand (Fedorikhin et al., 2008). The customers with emotional attachment with a brand become active brand advocates and make the brand active through higher level of involvement and word of mouth. The marketers can forecast the number of actual purchase of the brand, brand attitude, brand need and the purchase share of the brand through brand attachment (Whan Park et al., 2010). The strong attachment to a brand increases the brand loyalty among customers and they are ready to pay price premium. The customer's emotional attachment to a brand results in brand love, brand connection and brand affection and thus, consumer with strong brand attachment is more committed to the brand and maintain long term relationship with the firm (Thomson et al., 2005). So it is hypothesized that:

$H_{6}$ : Brand Love mediates the positive relationship between Self-Expressive Brands and Brand Advocacy.

$H_{7}$ : Brand Love mediates the positive relationship between Brand Attachment and Brand Advocacy.

Based on the above relationships between variables, the following framework is developed:

\subsection{Interpersonal relationship theory}

Triangular theory of interpersonal relationship is proposed by Sternberg (1986) in which he explained the interpersonal relationship among the three fundamental components of love (i.e., intimacy, passion, and decision/commitment). The theory states that a consumer develops strong bond and connectedness with a particular brand and tries to maintain love throughout his life because the brand develops symbolic meaning to consumer and becomes a part of his personal identity (Fournier, 1998). This feeling of love and attachment with the brand persuades him to produce positive 


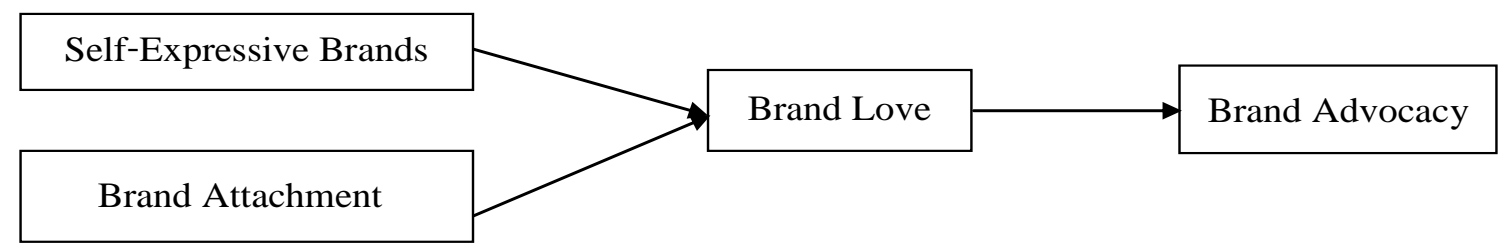

Figure 1: Research Model

statements about that brand (Ahuvia, 2005). The relationship strength is based on the combination of any of these three components which leads to brand advocacy (Rageh Ismail and Spinelli, 2012).

\section{Methodology}

\subsection{Sample and Procedure}

To figure out the impact of self expressive brands and brand attachment on brand advocacy with the mediating role of brand love, the primary data have to be collected. The population of the study includes the customers of Rawalpindi and Islamabad who used to wear branded clothes. The data were collected from both the male and female customers. The quantitative approach was used to focus on solving the problem under study. As the sampling framework was not available so the convenience sampling technique was used to collect data from the respondents within a given time period.

In the data collection process, self administered questionnaire was used to collect data about variables of the theoretical framework. $24.4 \%$ respondents were males and $75.6 \%$ were females. Most of customers belong to age group of $21-30$ years. There were $85.1 \%$ customers who belong to age group of $21-30$ years, $8.4 \%$ were from age group of Below 20 years, $4 \%$ were from age group of $31-40$ years while $2.5 \%$ were from age group of 41 and above. The data were gathered from students, housewives and job holders who mentioned their favourite clothing brands. There were $70.18 \%$ students, $8 \%$ housewives, $18.55 \%$ doing job in public and private sector while $3.27 \%$ were running their own independent business. Total 300 questionnaires were distributed, out of which 283 were given back by the respondents. There were 8 questionnaires in which data were missing. Thus 275 questionnaires were used for data analysis and the response rate was $92 \%$.

\subsection{Scales and Measures}

The eight items of Self Expressive Brands were adopted from Carroll and Ahuvia (2006) and measured on 5-point Likert scale. First sample item was "This clothing brand symbolizes the kind of person I really am inside". Brand Attachment was measured on 5- point Likert scale with three items that were adopted from Fournier (1998); Chang and Chieng (2006) and Thomson et al. (2005). The item includes "No other clothing brand can take the place of this brand". To measure Brand Love, ten items that were adopted from Carroll and Ahuvia (2006) and measured on 5- point Likert scale. The sample item of Brand Love was "This is a wonderful clothing brand". Brand Advocacy was measured using five items. It contains two dimensions: WOM ( 3 items) and Brand acceptance ( 2 items). The items of word of mouth were adopted from Unal and Aydin (2013) while items of brand acceptance were adopted from Carroll and Ahuvia (2006); \& Du et al. (2007). The items were measured on 5- point Likert scales. First item was "I recommend this brand to many people". SPSS software was used for data analysis. The population parameters are estimated through sample statistics and simple Linear Regression was run to test the hypothesis.

\section{Results}

Table 4.1: Reliability Analysis

\begin{tabular}{lcc}
\hline Variables & No of items & Alpha \\
\hline Self Expressive Brands & 8 & 0.876 \\
Brand Attachment & 3 & 0.797 \\
Brand Love & 8 & 0.811 \\
Brand Advocacy & 5 & 0.779 \\
\hline
\end{tabular}

For good reliability, the value of Cronbach's alpha should be in the range of $0.7-1$. Table 4.1 presented above shows that the Cronbach's alpha for self expressive brands 0.876 , brand attachment is 0.797 , brand love is 0.811 and brand advocacy is 0.779 . Hence, the questionnaire is considered as reliable for further research analysis.

\subsection{Correlation Matrix}

Table 4.2 shows the correlation among the variables. The results indicate that self expressive brand and brand attachment are positively and significantly correlated at $0.5252^{* *}(r=0.587)$. Similarly, self expressive brand is also positvely correlated with brand love 
Table 4.2: Means, Standard Deviations, Correlations \& Reliabilities

\begin{tabular}{lcccccc}
\hline Variables & Mean & S.D & SEB & B.ATT & BL & B.ADV \\
\hline Self Expressive Brands & 2.237 & 0.658 & 1 & & & \\
Brand Attachment & 2.521 & 0.845 & $0.525^{* *}$ & 1 & & \\
Brand Love & 2.132 & 0.576 & $0.624^{* *}$ & $0.587^{* *}$ & 1 & \\
Brand Advocacy & 2.146 & 0.558 & $0.529^{* *}$ & $0.457^{* *}$ & $0.688^{* *}$ & 1 \\
\hline
\end{tabular}

**. Correlation is significant at the 0.01 (99\%) level (2-tailed).

and brand advocacy with $\mathrm{p}$ at $0.624^{* *}$ and $0.529^{* *}$ respectively. Brand Love has strong positive impact on Brand Advocacy $\left(r=0.688\right.$, value of $\left.\mathrm{P}=0.01^{* *}\right)$ and Brand Attachment also has positive impact on Brand Advocacy at $\left(\mathrm{r}=0.475, \mathrm{P}=0.01^{* *}\right)$. The correlation values are less than 0.8 which shows that none of the variable is highly correlated and all the variables are significant at $99 \%$ confidence interval. Therefore, it provides initial support for all hypotheses. As all the variables have value less than 0.8 hence they all are considered as a separate construct.

\subsection{Regression Analysis}

Table 4.3 shows the results from regression analysis of mediation effect of brand love on the relationship between self expressive brands and brand advocacy and brand attachment and brand advocacy. To test the mediation analysis regression was run based on Preacher and Hayes model 4. The results shows that the self expressive brands has significant positive influence on brand love $(\beta=0.546, \mathrm{p}<0.05)$ and brand advocacy $(\beta$ $=0.138, \mathrm{p}<0.05)$. Brand attachment has a positive and a significant effect on brand love $(\beta=0.400, \mathrm{p}<0.05)$ while nonsignificant effect on brand advocacy with $(\beta$ $=0.053, \mathrm{p}>0.05)$. Brand love has significant impact on brand advocacy with $(\beta=0.568, \mathrm{p}<0.05)$. The effect size for both the mediation hypotheses with a $95 \%$ confidence interval was ( $\beta=0.310, \mathrm{CI}: 0.200$ to 0.429 ) and ( $\beta=0.248, \mathrm{CI}: 0.152$ to 0.340$)$ respectively. Since the $95 \%$ confidence interval does not contain zero it shows that the indirect effect is significant and the mediation is supported. So, it indicates that brand love partially mediates the relationship of self expressive brands and brand advocacy and fully mediates the relationship of brand attachment and brand advocacy. Therefore, the proposed hypotheses are accepted and proven to be true.

\section{Discussion}

The purpose of this study was to explore the impact of self-expressive brands and brand attachment on brand advocacy in the presence of brand love. The findings of this research are helpful starting point for future research, and provide managers the key to gain more customers attention through brand advocacy. The findings of first hypothesis showed that self expressive brand has positive impact on brand advocacy. The result is consistent with the proposed hypothesis and is similar to the results of Batra et al. (2012). Previous researches also identified the positive relationship between self expressive brands and brand advocacy. Wallace et al. (2014) revealed that the customers want to show others that what kind of personality they have so they prefer the brand which expresses their social selves among others and thus they have a high probability to accept new product from the same brand, produce positive words of mouth about it and forget the wrongdoing.

Brand attachment was found to have positive impact on brand advocacy. This is because, the brand attachment creates positive feeling towards a brand that

Table 4.3: Regression Analysis

\begin{tabular}{lllcccccc}
\hline Predictor & \multicolumn{1}{c}{ Outcomes } \\
\hline & \multicolumn{3}{c}{ Brand Love } & \multicolumn{4}{c}{ Brand Advocacy } \\
\hline Direct Effects & $\beta$ & SE & $\mathbf{t}$ & $\mathbf{p}$ & $\beta$ & SE & $\mathbf{t}$ & $\mathbf{p}$ \\
\hline Self Expressive Brands & $.546^{* *}$ & .041 & 13.198 & .000 & $.138^{* *}$ & .047 & 2.943 & .004 \\
Brand Attachment & $.400^{* *}$ & .033 & 11.975 & .000 & .053 & .036 & 1.483 & .139 \\
Brand Love & & & & & $.0568^{* *}$ & .054 & 10.583 & .000 \\
\hline Indirect effects & & & & $\beta$ & SE & LLCI & ULCI \\
\hline Brand Love & & & & & .310 & .059 & .200 & .429 \\
& & & & & .248 & .049 & .152 & .340 \\
\hline
\end{tabular}

${ }^{*} p=0.10,{ }^{* *} p=0.05,{ }^{* * *} p=0.001 ;$ ns $=$ not significant 
helps to develop interest in that brand and encourages maintaining the relationship with the brand in future and thus, the customers present favorable statement for a particular brand that can enhance the brand adoption and acceptance and become the brand advocate Keller (1993). Similarly, it was hypothesized that there is positive impact of self-expressive brands on brand love. The result of this hypothesis is in line with the previous study of Carroll and Ahuvia (2006). The customers create strong brand connection with a brand that is unique in nature. Because the customers consider that the brand has the ability to express their identity among their friends, relatives and peers (Kim \& Aimee, 2003). So they show strong love for the brands that helps them in determining their social self as well as their ideal self (Carroll and Ahuvia, 2006).

The relationship between brand attachment and brand love is also significant and the result is corresponding to the study of Loureiro et al. (2012). According to previous researches, consumers have strong feeling of attachment with their love objects (Fournier and Mick, 1999). The consumer with positive experience of a brand feels strong emotional attachment to that brand and that emotional attachment leads to brand love (Carroll and Ahuvia, 2006). Hence it is proved that there is positive impact of brand attachment on brand love. Moreover, brand love is found to have a positive impact on Brand Advocacy. This hypothesis is also accepted and the result is similar to the study of Bergkvist and Bech-Larsen (2010). Thomson et al. (2005) stated that brand love motivates the customers to develop strong connection with their favorite brand. This loved feeling encourages them to accept the brand and purchase it again and again. So, brand love leads them to greater brand loyalty, and thus, the customer produces positive words of mouth about that brand and develops long lasting relationship with it (Lee \& Workman, 2015).

The findings of hypothesis revealed that self expressive brands help in creating brand love which ultimately encourages the customers to become brand advocate. The result is similar to the findings of $\mathrm{Du}$ et al. (2007) and Wallace et al. (2014). According to Batra et al. (2012) the customers express their identity through their loved brand among others. As, self expressive brands help the customer in creating brand love. Thus, the feeling of love towards a brand leads towards brand advocacy (Du et al., 2007). So the self expressive brand has direct and positive impact on brand love and brand love mediates the relationship between self expressive brand and brand advocacy (Wallace et al., 2014). Similarly, the hypothesis that brand attachment has positive impact on brand advocacy in the presence of brand love is also accepted. The relationship of brand attachment and brand advocacy is fully mediated by brand love and this result is in line with past study of Carroll and Ahuvia (2006) and Loureiro et al. (2012). According to Loureiro et al. (2012) brand attachment has greater positive impact on brand love than self expressive brands. The strong brand attachment motivates the customer to maintain long lasting relationship with the brand and thus the customer shows willingness to pay for that brand. So it is concluded that strong brand attachment increases the brand loyalty among customers and push them to pay price premium (Thomson et al., 2005).

\subsection{Practical Implications}

The results of the present study show that brand love has partial mediating effect on the relationship between self expressive brands and brand advocacy and full mediating effect on the relationship between brand attachment and brand advocacy. So both the local and corporate managers can build the brand identity by communicating the message about the brand that is relevant to customers' identity (Loureiro et al., 2012). The positive influence of self expressive brands on brand love shows that the consumers show greater love to a brand which helps them to show their personal identity among others. Therefore, the managers should highlight the symbolic features of a brand so to leave positive and long lasting impression on customers, which will ultimately increase the customer's love for that brand (Biçakcioğlu et al., 2018). At the present time, this world became an emotional place where customer's decision making is greatly influenced by their feelings (Berry, 2000). Due to this reason, the managers must create emotional attachment between the consumers and brands (Levy and Hino, 2016), by introducing different promotional strategies so to attract the customer towards the brand. For instance, incentives program or family and friends programs, etc. help to keep the customer attached to the brand and thus feel emotional attachment to that brand (Lee and Workman, 2015). Furthermore, brand love is positively associated with brand advocacy so factors like brand quality, employee training could be considered to make sure that the customers' needs are fulfilled accordingly. This will make the customer more committed to the brand and will spread positive word of mouth about the brand. On the other hand, companies can also obtain some return on investment through such type of actions (Albert and Merunka, 2013).

\subsection{Limitations of Study}

There are few limitations of the study which were faced while conducting research process. First of all, the sample size for this research was very small (i.e., 275) due to which, the results of this research are not generalized at a large scale and are applicable only in the twin cities. Secondly, due to time constraint, convenience sampling was used to obtain customer's re- 
sponse which enhanced the biasness and produced narrow result. Sampling frame for this research was also not available due to which probability sampling technique could not be used. The variables such as brand hate, brand jealousy or other are not consider for defining brand love and a small sample was taken for the conducting the research accordingly. That is why, the study is not analyzed in detail and the dimensions of the variables are also not touched. There was also a financial constraint while conducting this research such as cost of printing, travelling and other expenditures.

\subsection{Directions for Future Research}

Some future research directions are provided to overcome the limitations of this study in order to explore the presented relationship more accurately. In future research, variables such as brand hate, brand jealousy brand trust should be taken as mediator in the model presented above. The dimensions of the variables should be study in order to get more precise result. The relationship of brand attachment and brand advocacy could be studied in future because the relationship is not thoroughly studied in previous researches. Further study should investigate the relationship between antecedents (consumer, brand or brand attributes etc) and brand love and which of the following have greater impact on brand love. Moreover, sampling technique other than convenient sampling should be used to get more appropriate results. In future, the research can be conducted in any other sector (e.g., footwear industry) and it will be interesting to consider different brands or product categories in the research context. Longitudinal research design can be used to avoid the common method biased. Sample size can also be increased to obtain the more accurate results.

\section{References}

Aaker, D. (2010). Marketing challenges in the next decade.

Aaker, J. L. (1997). Dimensions of brand personality. Journal of marketing research, pages 347-356.

Aggarwal, P. (2004). The effects of brand relationship norms on consumer attitudes and behavior. Journal of consumer research, 31(1):87-101.

Ahuvia, A. C. (2005). The love prototype revisited: A qualitative exploration of contemporary folk psychology. In University of Michigan-Dearborn Working Paper.

Albert, N. and Merunka, D. (2013). The role of brand love in consumer-brand relationships. Journal of Consumer Marketing, 30(3):258-266.

Albert, N., Merunka, D., and Valette-Florence, P. (2008). When consumers love their brands: Exploring the con- cept and its dimensions. Journal of Business research, 61(10):1062-1075.

Anderson, E. W. (1998). Customer satisfaction and word of mouth. Journal of service research, 1(1):5-17.

Baldwin, M. W., Keelan, J. P. R., Fehr, B., Enns, V., and KohRangarajoo, E. (1996). Social-cognitive conceptualization of attachment working models: Availability and accessibility effects. Journal of personality and social psychology, 71(1):94.

Batra, R., Ahuvia, A., and Bagozzi, R. P. (2012). Brand love. Journal of marketing, 76(2):1-16.

Berger, J. and Heath, C. (2007). Where consumers diverge from others: Identity signaling and product domains. Journal of Consumer Research, 34(2):121-134.

Bergkvist, L. and Bech-Larsen, T. (2010). Two studies of consequences and actionable antecedents of brand love. Journal of brand management, 17(7):504-518.

Berry, L. L. (2000). Cultivating service brand equity. Journal of the Academy of marketing Science, 28(1):128-137.

Biçakcıoğlu, N., İpek, İ., and Bayraktaroğlu, G. (2018). Antecedents and outcomes of brand love: the mediating role of brand loyalty. Journal of Marketing Communications, 24(8):863-877.

Bowlby, J. (2012). The making and breaking of affectional bonds. Routledge.

Bowman, D. and Narayandas, D. (2001). Managing customerinitiated contacts with manufacturers: The impact on share of category requirements and word-of-mouth behavior. Journal of marketing Research, 38(3):281-297.

Brodie, R. J., Ilic, A., Juric, B., and Hollebeek, L. (2013). Consumer engagement in a virtual brand community: An exploratory analysis. Journal of business research, 66(1):105114.

Carroll, B. A. and Ahuvia, A. C. (2006). Some antecedents and outcomes of brand love. Marketing letters, 17(2):79-89.

Cătălin, M. C. and Andreea, P. (2014). Brands as a mean of consumer self-expression and desired personal lifestyle. Procedia-Social and Behavioral Sciences, 109:103-107.

Chang, P.-L. and Chieng, M.-H. (2006). Building consumerbrand relationship: A cross-cultural experiential view. Psychology E Marketing, 23(11):927-959.

Chattopadhyay, A. and Laborie, J.-L. (2005). Managing brand experience: The market contact audit. Journal of Advertising Research, 45(1):9-16.

Du, S., Bhattacharya, C. B., and Sen, S. (2007). Reaping relational rewards from corporate social responsibility: The role of competitive positioning. International journal of research in marketing, 24(3):224-241.

Erdem, T. and Swait, J. (2001). Brand equity as a signaling. Journal of consumer Psychology, 7(2):131-157. 
Fedorikhin, A., Park, C. W., and Thomson, M. (2008). Beyond fit and attitude: The effect of emotional attachment on consumer responses to brand extensions. Journal of Consumer Psychology, 18(4):281-291.

Fournier, S. (1998). Consumers and their brands: Developing relationship theory in consumer research. Journal of consumer research, 24(4):343-373.

Fournier, S. and Mick, D. G. (1999). Rediscovering satisfaction. The Journal of Marketing, pages 5-23.

Georgescu, B., Nistoreanu, P., Anghel, L., Negoi, R., and Moise, D. (2011). Identifying the optimum price strategy of airlines companies for customer attraction and loyalty. Management of Technological Changes, pages 141-144.

Goldsmith, R. (2009). Conversational capital: How to create stuff people love to talk about. Journal of Consumer Marketing, 26(5):370-371.

Harrison-Walker, L. J. (2001). The measurement of wordof-mouth communication and an investigation of service quality and customer commitment as potential antecedents. Journal of service research, 4(1):60-75.

Hatfield, E. and Sprecher, S. (1986). Measuring passionate love in intimate relationships. Journal of adolescence, 9(4):383-410.

Hazen, C. and Shaver, P. (1987). Romantic love conceptualized as an attachment process. Journal of personality and social psychology, 52(3):511-524.

Herr, P. M., Kardes, F. R., and Kim, J. (1991). Effects of word-of-mouth and product-attribute information on persuasion: An accessibility-diagnosticity perspective. Journal of consumer research, 17(4):454-462.

Hwang, J. and Kandampully, J. (2012). The role of emotional aspects in younger consumer-brand relationships. Journal of Product $\mathcal{E}$ Brand Management, 21(2):98-108.

Jalilvand, M. R., Esfahani, S. S., and Samiei, N. (2011). Electronic word-of-mouth: Challenges and opportunities. Procedia Computer Science, 3:42-46.

Karjaluoto, H., Munnukka, J., and Kiuru, K. (2016). Brand love and positive word of mouth: the moderating effects of experience and price. Journal of Product \& Brand Management, 25(6):527-537.

Keller, K. L. (1993). Conceptualizing, measuring, and managing customer-based brand equity. the Journal of Marketing, pages 1-22.

Kim, J., Morris, J. D., and Swait, J. (2008). Antecedents of true brand loyalty. Journal of Advertising, 37(2):99-117.

Kleine, S. S., Kleine III, R. E., and Allen, C. T. (1995). How is a possession me or not me? characterizing types and an antecedent of material possession attachment. Journal of consumer research, 22(3):327-343.
Lee, S.-H. and Workman, J. E. (2015). Determinants of brand loyalty: self-construal, self-expressive brands, and brand attachment. International Journal of Fashion Design, Technology and Education, 8(1):12-20.

Levy, S. and Hino, H. (2016). Emotional brand attachment: a factor in customer-bank relationships. International Journal of Bank Marketing, 34(2):136-150.

Loureiro, S. M. C., Ruediger, K. H., and Demetris, V. (2012). Brand emotional connection and loyalty. Journal of Brand Management, 20(1):13-27.

Matzler, K., Pichler, E. A., and Hemetsberger, A. (2007). Who is spreading the word? the positive influence of extraversion on consumer passion and brand evangelism. Marketing Theory and Applications, 18(1):25-32.

Mazzarol, T., Sweeney, J. C., and Soutar, G. N. (2007). Conceptualizing word-of-mouth activity, triggers and conditions: an exploratory study. European Journal of Marketing, 41(11/12):1475-1494.

Pandir, B. and Yasin, B. (2017). Brand love and customer engagements role over brand loyalty. Journal of Management Marketing and Logistics, 4(4):359-365.

Park, C. W., MacInnis, D. J., and Priester, J. R. (2006). Beyond attitudes: Attachment and consumer behavior.

Rageh Ismail, A. and Spinelli, G. (2012). Effects of brand love, personality and image on word of mouth: The case of fashion brands among young consumers. Journal of Fashion Marketing and Management: An International Journal, 16(4):386-398.

Sashi, C. (2012). Customer engagement, buyer-seller relationships, and social media. Management decision, 50(2):253272.

Senecal, S. and Nantel, J. (2004). The influence of online product recommendations on consumers online choices. Journal of retailing, 80(2):159-169.

Sheeraz, M., Iqbal, N., and Ahmed, N. (2012). Impact of brand credibility and consumer values on consumer purchase intentions in pakistan. International Journal of Academic Research in Business and Social Sciences, 2(8):1.

Sternberg, R. J. (1986). A triangular theory of love. Psychological review, 93(2):119.

Thomson, M., MacInnis, D. J., and Whan Park, C. (2005). The ties that bind: Measuring the strength of consumers emotional attachments to brands. Journal of consumer psychology, 15(1):77-91.

Unal, S. and Aydin, H. (2013). An investigation on the evaluation of the factors affecting brand love. Procedia-Social and Behavioral Sciences, 92:76-85.

Wallace, E., Buil, I., and de Chernatony, L. (2014). Consumer engagement with self-expressive brands: brand love and wom outcomes. Journal of Product $\mathcal{E}$ Brand Management, 23(1):33-42. 
Wallendorf, M. and Arnould, E. J. (1988). my favorite things: A cross-cultural inquiry into object attachment, possessiveness, and social linkage. Journal of Consumer Research, 14(4):531-547.

Whan Park, C., MacInnis, D. J., Priester, J., Eisingerich, A. B., and Iacobucci, D. (2010). Brand attachment and brand at- titude strength: Conceptual and empirical differentiation of two critical brand equity drivers. Journal of marketing, 74(6):1-17.

Wragg, T. (2004). Nurturing brand advocates. Brand Strategy, 187:36-37. 


\title{
Prevalence of Post-Traumatic Stress Disorder and Its Impact on Job Satisfac- tion and Perceived Job Performance: Evidence from Afghanistan
}

\author{
Abdul Waheed ${ }^{1}$, Shabana Gul ${ }^{2}$,Muhammad Khan Riaz ${ }^{3}$, Muhammad Naeem*4, \\ 1,2,4 Institute of Management Sciences, Peshawar, Pakistan \\ ${ }^{3}$ COMSATS University, Attock, Pakistan
}

\begin{abstract}
The study investigated the prevalence of Post-Traumatic Stress Disorder PTSDand its impact on job satisfaction and perceived job performance in faculty members of private universities in Kabul, Afghanistan. The country has been affected by wars since 1979 USSR invasion, then civil war and now by ongoing war on terror. Utilizing questionnaires as data collection tool, 126 complete responses were received from six universities. Using a threshold score with help from literature, it was found out that in $65.08 \%$ respondents PTSD prevailed. The results showed that PTSD has significant negative impacts on job satisfaction and perceived job performance. Conclusively, the study suggests some recommendations for policy makers, especially the concerned institutions of the government of Afghanistan and the management of universities. These recommendations would help the concerned authorities to come up with certain solution plans, policies and strategies to cope up with the problem and reduce the level of PTSD and enhanced the psychological wellbeing of the faculty. This in return would help them attract some experienced professionals from across the globe and retain the current pool of talent for providing quality education to the citizens of Afghanistan which can help in paving the way to an educated and developed Afghanistan. Facilitating their safety and security can lead to a safe and secure mind without PTSD that can lead to increased productivity, loyalty and commitment which ultimately contribute to achieving organizational short and long run goals.

Key words: Post-Traumatic Stress Disorder, Job Performance, Perceived Job Performance, Afghanistan, Psychological Well-being.
\end{abstract}

\section{Introduction}

Afghanistan has been a war torn country for decades now and has experienced years of war, insecurity, terrorism, floods, earthquakes, issues and challenges that have had a destructive impact on the lives of Afghan people, institutions and organizations. Millions were killed, others were forced to leave the country and the infrastructure and institutions were destroyed. Currently Afghanistan is experiencing a period of transition while terrorist activities are at their peak causing stress to the people and affecting the transition process negatively. One of the main reasons for inefficiency besides corruption in Afghanistan may be the impact of traumatic events.

According to Zeidner et al. (2012) the majority of the worlds 450 million people with mental health problems are in developing countries and (WHO) the majority of them do not have access to treatment. Although the exact number of Afghans with mental health problems has not been identified yet; studies show that families in Afghanistan have lost one or more members

*Corresponding author.

Email: m.naeem00@yahoo.com during the 30 years of war. Studies by national and international organizations such as Care International and practitioners of Human Rights have indicated that a large portion of Afghanistan population (66\%) is affected by Post-Traumatic Stress Disorder PTSD as a result of war and use of weapons; approximately half of Afghans with more than 15 years of age are victims of PTSD.

Post-Traumatic Stress DisorderPTSD is associated with psychological problems and experienced as a result of traumatic event. Basically trauma is a disturbing experience having negative impact on behavior, working potential, interest, motivation, efficiency and productivity of employees which ultimately affects organization and the overall economy (Andersen et al., 1991; Clohessy and Ehlers, 1999). Stresses both internal and external had been ignored for years, internal, i.e. organization and job related stresses and external, i.e. family, society, economy and security that result in traumatic stress (Maes et al., 2001) affecting employees absenteeism and turnover (Blanchard et al., 1996); because they cant concentrate due to the problems they are facing. The same situation can be observed 
in Afghanistan, resulting in traumatic stress arising domestic and professional problems such as mess in work-life balance, low productivity and turnover.

Since 2001, as part of developments in Afghanistan, despite the unstable situation, economic activities have started, billions of dollars have been floating into Afghanistan, countries from across the world have started their aids and thousands of national and international organizations have been established and many national and international private universities have started delivering educational services to the people of Afghanistan, attracting both national and international staff with their attractive salary and benefit packages from across the globe, but yet they forgot to think about the most valuable resource of the organization, i.e. the human resources; hit by war and terrorism, greatly affecting their employees and their productivity.

Hence keeping in mind the past and current situation of Afghanistan it is decided to conduct this study in Kabul. The findings will facilitate giving a clear image of human resources in Afghanistan and suggest possible solution plans to the universities and Ministry of Higher EducationMoHEand meanwhile fulfill the partial requirement of Masters degree. This study aims to investigate the Prevalence of Post-Traumatic Stress Disorder and its impact on Job Satisfaction and Perceived Job Performance of Faculty Members of Private Universities in Kabul.

\section{Literature Review}

\subsection{Post-Traumatic Stress Disorder (PTSD)}

PTSD is a psychological response to seeing, hearing or experiencing an extremely stressing/ traumatic event such as war, physical torture, natural tragedy, accident, loss of someone close (Gilbert et al., 1988) kidnapping, terrorist attacks and other life frightening events (Tucker et al., 1999) resulting in a number of psychological, physiological and psychosomatic problems (Iribarren et al., 2005; Murthy and Lakshminarayana, 2006; Niaz et al., 2006) such as flashbacks, depression, nightmares, regular avoidance of reminders of the event, insomnia, memory related problems, anxiety disorders, and drug abuse, negatively affecting the abilities and performance of the affected individual (Breslau, 2001). Meanwhile, employees who are more exposed to terrorist activities experience more signs of post-traumatic Stress disorder (Hodgins et al., 2001).

Post-traumatic stress disorder was initially found in people who have been through traumatic situation in their lives e.g. war veterans, assault and terrorism victims (Maes et al., 2001) and got prominence after the Vietnam war. The war veterans in different countries especially Vietnam, Iraq, and Afghanistan are experi- encing serious PTSD during and after the war missions. The concentration on PTSD was initially started after the Vietnam war where the focus of the researchers were the ex-army officers who had served in Vietnam war, however less attention was given to general public; since then works regarding general definition, nature, detections, measurement, treatment and management have been done.

Humans in their personal and professional lives go through many different stages, experiences, surprises and events, i.e. joy events and different traumatic events. As human is the most complex and unpredictable animal in nature, it becomes difficult for them to cope up with certain situations and people. They usually face difficulties and problems while adjusting and coping with certain problems, which give birth to posttraumatic stresses, although these stresses can be overcome by taking care of themselves, but sometimes it is difficult which in return gives birth to traumatic stress disorders (Cardena et al., 1991). Experiencing stress after traumatic event is usual and results in some kind of reactions like feeling afraid or having no control over what is happening and think that his/her life or others' lives are in danger. Meanwhile, after experiencing a traumatic event everyone doesnt develop PTSD but very few people do. Though causes of PTSD are not definite, but researchers believe that PTSD may be influenced by the persons personality, some heredity makeup and gravity of an event. Statistics shows that female gender, children in the house, ethnic minority, middle-aged, lower socioeconomic status, pre-existing psychiatric conditions, primary exposure to the event including injury, life-threatening situation, loss, and women with children are more likely to exhibit PTSD (Alexander and Wells, 1991). Men are more likely to experience trauma as a result of accidents, physical assault, combat, disaster, and death or injury; while women are more likely to experience trauma as a result of sexual assault. Meanwhile, children may also develop PTSD having the same symptoms discussed above or other symptoms depending on their age. Their symptoms are more likely to change to those of adults as they grow.

Sometimes direct victims of trauma believe that they or their family members are in danger resulting in severe reaction during the event, such as crying, shaking, vomiting or feeling apart from the surrounding; meanwhile, feeling helplessness during trauma would more likely to develop PTSD. Also, people who are poorly educated, women, young people, previous victims of trauma, people with other mental problem, or having any family member with mental problems, little support from family and friends, and recent loss of a loved one, would more likely to develop PTSD. Culture also plays a role in how one reacts to trauma. People from societies that are open and are willing to talk about problems are more likely to seek help for iden- 
tifying, curing and managing the trauma in time. The survey shows that about $5 \%$ of PTSD cases are as a result of natural disasters, while about $50 \%$ of cases are of rape and survivors of the destruction (Christen et al., 2002; Creamer and Liddle, 2005). Initial studies confirm that factors such as age, family patterns, and initial experience of violence probably play a major role in the development of post- traumatic stress disorder (Corneil et al., 1999; O'brien, 1984; Selley et al., 1991).

Stress is categorized into chronic stress and acute stress. Chronic stress is the conflict associated with balancing ones work, situation or environment with another, i.e. work-family life balance. Chronic stress is ongoing and usually lasts longer. While acute stress is a traumatic event employee faces during organizational restructuring, terrorist attack, and natural disaster, it is shorter in duration but it can be longer than chronic stress disorder. Acute stress is also called a traumatic stress (Alexander and Wells, 1991). Symptoms of acute stress last for less than three months and if the duration exceeds then it is chronic. The causes and symptoms of PTSD are different for different people depending on the conditions victims go through.

Research shows that job related stress has a huge impact on the physical and psychological health of employee but few types of researches have focused on the impact of post-traumatic stress and their effect on the individual employee and organizational outcomes (Andersen et al., 1991; Clohessy and Ehlers, 1999). Recently researchers have started inspecting the effect of PTSD on individual employees and organizational outcomes (Association et al., 1980) and most of the organizations have been focusing on organizational stresses to overcome traumatic events that lead to stress (Blanchard et al., 1996) because studies revealed that organizational stress has a costly and negative impact on the organization and its employees (Epstein et al., 1998; Tjemsland et al., 1998). On the other hand traumatic events in personal life also have a negative impact on employees professional life usually resulting in absenteeism (Maes et al., 2001; McFarlane, 2000). PTSD can be developed as a result of both man-made and natural traumatic events, and employees who work with victims are more likely to develop stress (Weiss, 2002).

The exposure of symptoms differ from person to person (Fox and Lief, 1963; Halpern, 2001) some may experience it for a longer time, while in some cases trauma may become chronic. It usually shows up within three months of the event but sometimes it may take a year, but once the symptoms show up they may go away within six months, so the person should keep track of the symptoms, because it disturbs the normal life of the victim. Literature suggests that factors such as exposure to trauma, degree of loss, fear, history of mental illnesses, etc. increase the risk of PTSD (Niaz et al., 2006). If the above mentioned symptoms exist for more than four weeks, resulting in stress and dis- turbing your domestic and work life, you might have PTSD and would need professional help from a doctor or counselor. Those symptoms fall into four categories; Re-living the event (Re-experiencing symptoms); regular and repeated occurrence of trauma, resulting in flashbacks, repeated painful memories or nightmares, Avoiding situations that remind you of the event; trying to avoid situations or people that remind memories of the traumatic event, Negative changes in beliefs and feelings; thinking may change about oneself and others, not in good mood, lack of interest in routine life and activities which an individual used to enjoy, carelessness and detachment from others; Hyper-arousal, nervous or always on the lookout for danger, become more sensitive and lose temper easily, may face difficulty in concentration alertness, and sleeping (Dweck, 2013; Edmondson et al., 2001). While the three major types of PTSD are: Sudden great damages, events that are natural disaster such as earthquakes, etc. Accidental Suffering such as airplane crashes, deaths and accidents; Human induced disaster like war, kidnapping, robbery, hijack, and murder, etc.

Experts say that causes of mental health illnesses are not limited to war, domestic violence, extreme poverty but lack of access to treatment and rehabilitation also cause mental illnesses and even watching videos of victims or the incident may also develop PTSD which means that Traumatic event does'nt just affect the ones directly involved, but may affect people worldwide. In Afghanistan violence ranges from armed insurgency to family conflict (UK medical journal, The Lancet) and war causing mental health problems to many Afghans (Musadi Nadimee). The war in Vietnam, Iraq, and Afghanistan, and earthquakes in Japan, AJK, KPK and Tsunami have forced the professionals to realize the cost of these disasters which didnt only cause damages to properties, but also resulted in disabilities and loss of lives (Goenjian et al., 1994).

Research indicates higher prevalence of PTSD in females and children as compared to men, because fear dominate their mind and make them suffer longer; while Telles et al. (2009) observed higher prevalence of mental health problems in aged people in Bihar, India. Studies show that PTSD is higher in people of age eighteen and higher in comparison to victims under eighteen and the risk of PTSD as a result of natural events is higher in victims of age 35-54years. Atta (2013) has investigated prevalence of PTSD in the school teachers of 2010 flood affected district, Nowshera; (Wali et al., 2018) have investigated PTSD occurrence in Khyber Agency, and both of them found that nearly all the respondents were victims of PTSD.

Stress and disturbance is usual after a traumatic event and victims get better in time, but if the symptoms last longer than three months the victims are required to seek help before it disturb their personal and professional life. PTSD can be treated access to help 
and coping skills (proper management and treatment) can effectively control it to avoid the interference of the symptoms in everyday activities, work and relationships but it doesn't always guarantee recovery. There are two ways of treatment, e.g. psychotherapy (counseling) and medication. The nature of treatment depends on the intensity and nature of the trauma, sometimes both the psychotherapy and medication are combined, while in some cases they are used separately. In psychotherapy (counseling) the patient meets with a therapist and goes through certain psychotherapies such as The Cognitive Processing Therapy, involves learning skills to understand how trauma changed victims thoughts and feelings; Prolonged Exposure Therapy is where victim are asked to talk about trauma repeatedly until memories are no longer disturbing and going to places that are safe, but avoided because they were related to the trauma and the Eye Movement Desensitization and Reprocessing involves focusing on sounds or hand movement while talking about the trauma. Medication can also be effective for PTSD treatment where different types of medicines are used for depression and nightmares

Post-Traumatic stress is actually an environmental issue in or outside the workplace negatively effecting employee and organization (Maes et al., 2001), and urging employees to leave the organization due to the situation they are facing (Blanchard et al., 1996). These factors caught the attention of organizations toward employees with PTSD and forced them to work with researchers on policies to overcome and limit the effect of stressors and traumatic events employees face in their workplace (Epstein et al., 1998).

\subsection{Job Satisfaction}

Satisfaction is the achievement of desires (Thorndike and Barnhart, 1988). Thus a person is satisfied when his/her needs or desires are fulfilled. Theories of satisfaction have been recommended by Maslow (1954) and Herzberg and Mausner (1959). According to Maslow, a person is satisfied when his/her five basic needs such as physiological, safety, affiliation, selfesteem and self-actualization needs are accomplished; whereas Herzberg had introduced motivation-hygiene theory that focuses on two factors which determine a persons satisfaction. First the factors that cause job satisfaction in the workplace and others that cause dissatisfaction. Motivators are used for positive satisfaction through internal factors such as recognition, achievement or personal growth; while in absence of hygiene factors such as company policies, supervisory practices, wages dissatisfaction arises (Herzberg and Mausner, 1959).

Job satisfaction refers to a complete set of positive feelings linked to the job; increasing the positive attitude of employee toward his/her job, if an individual is satisfied from his job, he may show interest in his job and fulfill his responsibilities efficiently and dissatisfaction about the job may cause stress, physical complaints and interpersonal conflict to an individual which may affect his/her performance and the performance of organization as a whole. Nelson (2006) valued employee satisfaction because Dissatisfaction adversely affects the desire to do the job and dissatisfied employees are less dedicated to the company which in turn affects their performance and the performance of the entire organization.

Research shows a direct relation between Job satisfaction, efficiency and individual comfort. Many definitions have been suggested by different people; Locke (1976) described job satisfaction as an enjoyable state that results from the positive assessment of job experiences and achievements in work. It is actually a positive change in behavior that indicates how employees feel about their job and focus on direct response to several factors in the workplace (Mowday et al., 1982); while Weiss (2002) called it an attitude of having an obvious difference among beliefs, behaviors and emotions which shape cognitive evaluation. Job satisfaction plays a vital role in an organization, because it is linked to the efficiency in job (Bazerman et al., 1998).

A variety of factors such as the nature of relationship with the subordinates, working environment, level of achievements in work, determine job satisfaction. There are certain factors that affect the level of satisfaction; organization identification is one of the factors that influence the level of employees satisfaction. The higher the organizational identification is, the more the job satisfaction (Brewer, 1994). An individuals capability of fulfilling given tasks, communication, the behavior of the top management and self interest in the workplace which is linked with pay, working hours and benefits, are other factors that may enhance Job satisfaction. Meanwhile, breach of contract may also cause dissatisfaction Wanous (1973); because the difference between what is predicted or promised and what is obtained can be a key factor of dissatisfaction and can decrease satisfaction of employees (Pieterse, 2015). When mutual agreement made between the employee and company is not fulfilled, employee may be dissatisfied resulting in absenteeism and a higher rate of turnover (Griffeth et al., 2000; Hacket, 1989). Dissatisfaction may result in delivering low quality of services, destructive rumors, robbery and destruction of organization asset, which is costly for the organization (Spector, 1997). On the other hand anxiety, disrupted sleep pattern, exhaustion, depressive disorders are usual in dissatisfied employees (Frese, 1985; O'brien and Kabanoff, 1979; Spector, 1997) which affects employees emotions and welfare. Job satisfaction is based on intrinsic and extrinsic factors, where intrinsic Factors include recognition, advancement, responsibilities and achievements; extrinsic factors include salary, work condition, regu- 
lation and administrative policies Griffeth et al. (2000). Job satisfaction in teachers differs from individual to individual. Meanwhile, the factors affecting their job satisfaction mostly include working conditions, balance of workload, self-efficacy, management attitude, students behavior and salary (Griffeth et al., 2000).

The theories established to elaborate the factors affecting job satisfaction are broadly classified into two perspectives: process theories and content theories. Process theories deal with the "process" of how motivation occurs. It includes variables like values, expectations, desires, and insights and how there variables relate to seek job satisfaction. Content theories deal in "what" motivates people and are usually linked with individual needs and goals. The two leading theories in this regard are need hierarchy theory by Maslow (1954) and Motivation-Hygiene theory by Herzberg and Mausner (1959), which is also called two factor theories (Manisera et al., 2005).

\subsection{Perceived Job Performance}

Job performance is under the focus of industrial and organizational psychology, and human resources management because performance plays important role in success and achievements of organizational goals. According Campbell, job performance is a micro level variable linked with an individual as compared to organizational performance. Performance is a behavior an individual shows and deals with how an individual perform in achieving the goals. According to Laitinen (2002) performance is the ability of something or someone to produce results against a pre-determined target. While Perceived job performance is the perception of one's self about something he/she does. Researchers agree that effort, compensation, quality of supervision and clarity of job responsibility are the common predecessors of job satisfaction and job performance (Christen et al., 2006).

PTSD may affect workers and also influence the work environment (McFarlane, 2000). Workers with PTSD may go into conflict with peers, subordinates and management. Meanwhile, Riaz et al. (2016) have investigated PTSD prevalence and its impact on the performance of small businesses in Peshawar and Kohat and found that the prevalence of PTSD in small business owners affected their businesses and the performance of business owner depends on his cognitive abilities, psychological wellbeing and health condition. So we can conclude that PTSD affects the performance of owner negatively, affecting the overall performance of the business, because the performance of business is linked to its leadership and management performance. Shahzad et al. (2008) examined the relationship between three HR practices (compensation, promotion and performance evaluation) and perceived employee performance of university teachers in Pakistan. They found that positive relationship between compensation and promotion practices and employee perceived performance.

In the light of above review of literature, following hypotheses are put forth:

$H^{1}$ : Post-Traumatic Stress Disorder effects job satisfaction.

$H^{2}$ : Post-Traumatic Stress Disorder has a negative impact on employees perceived job performance.

\section{Methodology}

\subsection{Population and Sampling}

Current study is the correlational study and the primary focus of the current research is to investigate the prevalence of PTSD and its impact on job satisfaction and perceived job performance in faculty members of private universities in Kabul, the population for this research comprises of faculty members of private universities in Kabul, who will serve as the respondents for this research. Data for this research is collected from six universities of Kabul (see table 3.1).

The sample is drawn using twofold stratified sampling techniques. 6 out of the 49 private Higher Education InstitutesHEIs were chosen in first stage. In the next stage proportionate sample of 200 faculty members was drawn from these six HEIs. Data were collected through self-administered questionnaire in person from the faculty members of private universities in Kabul city. Heads of Departments of each university were approached. Upon approval, questionnaires were administered. A total of 180 questionnaires were distributed among respondents. 150 were returned (83.34\% response rate). After checking, it was found that 24 questionnaires were not filled properly which means that a total of 126 questionnaires were found analysis ready.

A total of 126 questionnaires were analyzed. $21.43 \%(n=27)$ of the respondents were bachelors, $56.35 \%(n=71)$ were masters, $18.25 \%(n=23)$ were MPhil/MS while the remaining $3.97 \%(n=5)$ of the respondents were PhD scholars. Majority of the respondents, $72.22 \%(n=91)$ were Afghan nationals, while the remaining 27.78(n=35) were Pakistani. Ethnically majority of the respondents $57.94 \%(n=73)$ were Pakhtun while Tajik counted for $29.37 \%(n=37)$, and Hazara respondents counted for $8.73 \%(n=11)$ and the rest of the respondents; Panjabi, Hindko Nooristani, and Qazalbash counted for $3.96 \%(n=4)$. 


\section{Measures}

\subsection{Post-Traumatic Stress DisorderPTSD}

PTSD Check List for Civilian (PCL-C) a 17 items construct on a Likert scale ( 1 for not at all to 5 for extremely) is used (Weathers et al., 1994). The score of respondents on PCL-C ranges from 17 to 85 . Cronbach Alpha was 0.844 .

\subsubsection{Job Satisfaction}

A five Likert items (five points) measure developed by Babin and Boles (1998) was used to measure job satisfaction, with the Cronbach Alpha value at .883.

\subsubsection{Perceived Job Performance}

The perceived Job Performance Scale (JPS) was developed by Brown and Leigh (1996). It consists of 10 items divided into time commitment and work intensity each consist of five items with a Likert rating scale of 5 points, ranging from strongly disagree to strongly agree. Its Cronbach Alpha was 0.766

\section{Results}

\subsection{PTSD Prevalence}

Version four (DSM-IV) of Diagnostic and Statistical Manual of Mental Diseases has suggested two criteria (National-Center-for-PTSD, 2014) for prevalence of PTSD, i.e. there be at least one $\mathrm{B}$ (a little bit) response in items1-5, three $C$ (moderate) responses in items 6-12, and at least two D (quite a bit) responses in items1317 , and/or a threshold score may also be used. While checking the questionnaires it was found that all respondents met the first criteria. For second criterion, a threshold score of 38 is used which means that whose total PCL score is greater than 38, they shall be considered victim of PTSD. This threshold score is used as standard in this study because Niaz et al. (2006) in NWFP and by Riaz et al. (2016) in frontier region of Peshawar and Kohat used it and it is known that Khyber Pakhtunkhwa and Afghanistan share their social and cultural values and have been hit by the ongoing war on terror. Out of 126 questionnaires, 82 respondents which count for $65.08 \%$ of the total samples are victims of PTSD while other 44 respondents which actually counts for $34.92 \%$ of the total samples indicates Non-PTSD victims.

\subsection{Data Analysis and Hypo-testing}

To check the first hypothesis Post traumatic stress has a negative impact on job satisfaction linear regression was applied. R2 value was 0.529 with $\mathrm{F}(126.1)=$ $166.472(\mathrm{p}<.000)$ with $\beta$ PTSD of -.540 , which supports the fact that PTSD has a significant negative impact on employee Job satisfaction. Thus H1 is supported and accepted.

Similarly, PTSD was regressed against perceived job performance. The regression results showed R2 value was 0.515 with $F(12.61)=157.062(p<.000)$ with $\beta$ PTSD of -.297 which supports the fact that PTSD has significant negative impact on perceived employee job performance. Thus $\mathrm{H} 2$ is also supported and accepted.

\section{Discussion and Conclusion}

This research was conducted to examine the prevalence of post-traumatic stress disorder and its impact on job satisfaction and perceived job performance of faculty members of private universities in Kabul, Afghanistan that have been affected by decades of war and the ongoing war on terror. The study found that faculty members of private universities were victims of PTSD and PTSD negatively affects employees job satisfaction and perceived job performance.

While studies show that job related stress has a huge impact on physical and mental health of employee, few researches have been done to investigate the impact of post- traumatic stress on individual employees and organizational outcomes (Andersen et al., 1991; Clohessy and Ehlers, 1999), but now researchers are studying it (Association et al., 1980) and most of them have focused on organizational stresses to overcome disturbing events that lead to stress (Blanchard et al., 1996) because studies disclose that extra organizational stress has a costly and negative impact on organization and its employees (Epstein et al., 1998; Tjemsland et al., 1998). Exposure to PTSD may affect workers and also influence the work environment (McFarlane and Bryant, 2007) workers with PTSD may go into conflict with peers, subordinates and management that may in return affect their mental wellbeing in many ways. Meanwhile, PTSD in small business owners badly affected their businesses and the performance of business owner depends on his cognitive abilities, psychological wellbeing and health condition (Riaz et al., 2016). So we can conclude that PTSD can affect the performance of owner negatively which can affect the overall performance of the business because the performance of any business is linked to its leadership and management performance.

This study is the first one in its nature in Afghanistan, was conducted keeping in mind the past and current situation of Afghanistan, to give a clear image of human resources and suggest possible solution plans to the ministry of higher education and universities to come up with certain policies, procedures and strategies to overcome stresses and let the employees work in a safe environment with peaceful mind. Analysis of this study reveals that $65.08 \%$ of the respondents 
are victims of PTSD and other $34.92 \%$ are non-victims and support a significant relation between PTSD and job satisfaction and perceived job performance. So we can conclude that PTSD has a significant impact on job satisfaction and perceived job performance of faculty members of private universities in Kabul, Afghanistan.

\subsection{Future directions}

There are some suggestions for future researches; this research is limited to the private universities in Kabul, if the researcher expands the area of sampling to other provinces and involves public sector universities that may get different result. This study is limited to samples from only 6 private universities in Kabul city and had data from a limited number of 126 respondents, if future researchers incorporate larger sample based on gender, age, culture and nationality and involves mediators such as Self Efficacy into studying the impact of PTSD on Job Satisfaction and Perceived Job Performance that may get different results and measure different levels of PTSD and its impact on job satisfaction and perceived job performance.

Controlling the impact of PTSD is not always easy and cannot be done without actually controlling the prevalence of PTSD. Once the prevalence of PTSD is controlled then it is possible to decrease and overcome its impact on individuals. The major institutions that can play role in controlling the prevalence of PTSD and its impact on individuals are government, security agencies and MoHE who are the major policy makers in Afghanistan and then the universities. The study recommends the policy makers to work on plans for rehabilitation of affected ones and also provides some suggestions that would help in lowering its impact. On the government side; no private higher education institute should be let free. A regulatory and supervisory committee should be established to control and monitor the institutes and meanwhile regulations must be updated on regular basis as required. A collaboration between MoHE and the security agencies are needed, first and the most important is the location of universities and their guest houses; government should work on plans regarding provision of lands and buildings to universities in a relatively safe and calm areas of the city which on one hand would help overcome the level of PTSD and on another hand will provide a relatively calm place for both the faculty members and the students away from crowd and insecurity. Secondly, they must work on making plans regarding provision of security to the universities and their personnel in and outside the educational institutes because education is the backbone of a country and directs a country towards development.

While on the universities side, first of all the environment of educational institutes should be friendly and free of any kind of discrimination, especially gen- der discrimination. Universities must brief their employees, especially non-Afghans about situations, especially security situations in Afghanistan upon their arrival.

Secondly, work together with government institutions for acquiring location in the safe and calm areas of the city and work on plans regarding security measures in and outside the university.

Thirdly, effective programs must be implemented either by MoHE or the institutions themselves to fight against violence. Faculties' staff must be trained and regular trainings, seminars and briefings to their employees would be helpful in giving them information about the situation in Afghanistan and equipping them with several self-care and defense actions and techniques to protect themselves in unwanted situations that lead to stress.

And finally, universities must hire psychologist and psychological consultants who will regularly check the psychological wellbeing of employees and help them in overcoming and meanwhile work with employees and train them for self-care and safety in groups and individually.

\section{References}

Alexander, D. A. and Wells, A. (1991). Reactions of police officers to body-handling after a major disaster a beforeand-after comparison. The British Journal of Psychiatry, 159(4):547-555.

Andersen, H. S., Christensen, A. K., and Petersen, G. O. (1991). Post-traumatic stress reactions amongst rescue workers after a major rail accident. Anxiety research, 4(3):245-251.

Association, A. P. et al. (1980). Diagnostic and statistical manual of mental disorders; dsm-iii. Washington DC.

Babin, B. J. and Boles, J. S. (1998). Employee behavior in a service environment: A model and test of potential differences between men and women. The Journal of Marketing, pages 77-91.

Bazerman, M. H., Tenbrunsel, A. E., and Wade-Benzoni, K. (1998). Negotiating with yourself and losing: Making decisions with competing internal preferences. Academy of Management Review, 23(2):225-241.

Blanchard, E. B., Hickling, E. J., Barton, K. A., Taylor, A. E., Loos, W. R., and Jones-Alexander, J. (1996). One-year prospective follow-up of motor vehicle accident victims. Behaviour research and therapy, 34(10):775-786.

Breslau, N. (2001). Outcomes of posttraumatic stress disorder. The Journal of clinical psychiatry.

Brewer, A. (1994). The responsive employee. Allen and Urwin Pub. Sydney, Australia. 
Brown, S. P. and Leigh, T. W. (1996). A new look at psychological climate and its relationship to job involvement, effort, and performance. Journal of applied psychology, 81(4):358.

Cardena, E., Classen, C., and Spiegel, D. (1991). Stanford acute stress reaction questionnaire. Department of Psychiatry and Behavioural Sciences. Stanford Medical School.

Christen, H. T., Maniscalco, P. M., and Christian, H. T. (2002). Mass casualty and high-impact incidents: an operations guide. Brady.

Christen, M., Iyer, G., and Soberman, D. (2006). Job satisfaction, job performance, and effort: A reexamination using agency theory. Journal of Marketing, 70(1):137-150.

Clohessy, S. and Ehlers, A. (1999). Ptsd symptoms, response to intrusive memories and coping in ambulance service workers. British journal of clinical psychology, 38(3):251-265.

Corneil, W., Beaton, R., Murphy, S., Johnson, C., and Pike, K. (1999). Exposure to traumatic incidents and prevalence of posttraumatic stress symptomatology in urban firefighters in two countries. Journal of occupational health psychology, $4(2): 131$

Creamer, T. L. and Liddle, B. J. (2005). Secondary traumatic stress among disaster mental health workers responding to the september 11 attacks. Journal of Traumatic Stress: Official Publication of The International Society for Traumatic Stress Studies, 18(1):89-96.

Dweck, C. S. (2013). Self-theories: Their role in motivation, personality, and development. Psychology press.

Edmondson, A. C., Bohmer, R. M., and Pisano, G. P. (2001). Disrupted routines: Team learning and new technology implementation in hospitals. Administrative Science Quarterly, 46(4):685-716.

Epstein, J. N., Saunders, B. E., Kilpatrick, D. G., and Resnick, H. S. (1998). Ptsd as a mediator between childhood rape and alcohol use in adult women. Child Abuse E Neglect, 22(3):223-234.

Fox, R. and Lief, H. (1963). Training for detached concern.. The Psychological Basis of Medical Practice. New York, NY: Harper \& Row, pages 12-35.

Frese, M. (1985). Stress at work and psychosomatic complaints: a causal interpretation. Journal of applied psychology, $70(2): 314$.

Gilbert, D. T., Pelham, B. W., and Krull, D. S. (1988). On cognitive busyness: When person perceivers meet persons perceived. Journal of personality and social psychology, 54(5):733.

Goenjian, A. K., Najarian, L. M., Pynoos, R. S., Steinberg, A. M., et al. (1994). Posttraumatic stress disorder in elderly and younger adults after the 1988 earthquake in armenia. The American Journal of Psychiatry, 151(6):895.
Griffeth, R. W., Hom, P. W., and Gaertner, S. (2000). A meta-analysis of antecedents and correlates of employee turnover: Update, moderator tests, and research implications for the next millennium. Journal of management, 26(3):463-488.

Hacket, R. D. (1989). Work attitudes and employee absenteeism: A synthesis of the literature. Journal of occupational psychology, 62(3):235-248.

Halpern, J. (2001). From detached concern to empathy: humanizing medical practice. Oxford University Press.

Herzberg, F. M. and Mausner, B. (1959). B. \& snyderman, b.(1959). The motivation to work, 2.

Hodgins, G. A., Creamer, M., and Bell, R. (2001). Risk factors for posttrauma reactions in police officers: A longitudinal study. The Journal of nervous and mental disease, 189(8):541547.

Iribarren, J., Prolo, P., Neagos, N., and Chiappelli, F. (2005). Post-traumatic stress disorder: evidence-based research for the third millennium. Evidence-Based Complementary and Alternative Medicine, 2(4):503-512.

Laitinen, E. K. (2002). A dynamic performance measurement system: evidence from small finnish technology companies. Scandinavian journal of management, 18(1):65-99.

Locke, E. A. (1976). The nature and causes of job satisfaction. Handbook of industrial and organizational psychology.

Maes, M., Mylle, J., Delmeire, L., and Janca, A. (2001). Preand post-disaster negative life events in relation to the incidence and severity of post-traumatic stress disorder. Psychiatry Research, 105(1-2):1-12.

Manisera, M., Dusseldorp, E., and Van Der Kooij, A. J. (2005). Component structure of job satisfaction based on herzbergs theory. Rapporti di Ricerca del Dipartimento di Metodi Quantitativi, Brescia University, Working paper, 253.

Maslow, A. H. (1954). The instinctoid nature of basic needs 1 . Journal of Personality, 22(3):326-347.

McFarlane, A. C. (2000). Posttraumatic stress disorder: A model of the longitudinal course and the role of the risk factors. The Journal of clinical psychiatry.

McFarlane, A. C. and Bryant, R. A. (2007). Post-traumatic stress disorder in occupational settings: anticipating and managing the risk. Occupational Medicine, 57(6):404-410.

Mowday, R. T., Porter, L. W., and Steers, R. M. (1982). Employee-organization linkage. The psychology of commitment absenteism, and turn over_Academic Press Inc. London.

Murthy, R. S. and Lakshminarayana, R. (2006). Mental health consequences of war: a brief review of research findings. World psychiatry, 5(1):25.

Nelson, N. (2006). A little appreciation can go a long way toward employee job satisfaction. Employment Relations Today, 33(1):19-26. 
Niaz, U., Hassan, S., Hassan, M., Hussain, H., and Ahad, S. (2006). Prevalence of post-traumatic stress disorder and comorbid depression in earthquake survivors in nwfp, pakistan: a preliminary study. Journal of Pakistan Psychiatric Society, 3(July-December Number 2):98.

O'brien, G. E. (1984). Reciprocal effects between locus of control and job attributes. Australian Journal of Psychology, 36(1):57-74.

O'brien, G. E. and Kabanoff, B. (1979). Comparison of unemployed and employed workers on work values, locus of control and health variables. Australian Psychologist, 14(2):143-154.

Pieterse, D. (2015). Childhood maltreatment and educational outcomes: Evidence from south africa. Health economics, 24(7):876-894.

Riaz, M. K., Jamal, W., and Jan, F. A. (2016). I, we and you: A study of relationship of individualism-collectivism and conflict management styles.

Selley, M., Lacey, M., Bartlett, M., Copeland, C., and Ardlie, N. (1991). Content of significant amounts of a cytotoxic end-product of lipid peroxidation in human semen. Journal of reproduction and fertility, 92(2):291-298.

Shahzad, K., Bashir, S., and Ramay, M. I. (2008). Impact of hr practices on perceived performance of university teachers in pakistan. International review of business research papers, 4(2):302-315.

Spector, P. E. (1997). Job satisfaction: Application, assessment, causes, and consequences, volume 3. Sage publications.

Telles, S., Singh, N., and Joshi, M. (2009). Risk of posttraumatic stress disorder and depression in survivors of the floods in bihar, india. Indian Journal of Medical Sciences, 63(8):330-330.

Thorndike, E. L. and Barnhart, C. L. (1988). Scott, Foresman advanced dictionary. Scott Foresman \& Co.

Tjemsland, L., Søreide, J. A., and Malt, U. F. (1998). Posttraumatic distress symptoms in operable breast cancer iii. Breast Cancer Research and Treatment, 47(2):141-151.

Tucker, P., Pfefferbaum, B., Nixon, S. J., and Foy, D. W. (1999). Trauma and recovery among adults highly exposed to a community disaster. Psychiatric Annals, 29(2):78-83.

Wali, N., Chen, W., Rawal, L. B., Amanullah, A., and Renzaho, A. M. (2018). Integrating human rights approaches into public health practices and policies to address health needs amongst rohingya refugees in bangladesh: a systematic review and meta-ethnographic analysis. Archives of Public Health, 76(1):59.

Wanous, J. P. (1973). Effects of a realistic job preview on job acceptance, job attitudes, and job survival. Journal of applied psychology, 58(3):327.

Weathers, F. W., Litz, B. T., Herman, D., Huska, J., and Keane, T. (1994). The ptsd checklist-civilian version (pcl-c). Boston, MA: National Center for PTSD.

Weiss, H. M. (2002). Deconstructing job satisfaction: Separating evaluations, beliefs and affective experiences. Human resource management review, 12(2):173-194.

Zeidner, M., Matthews, G., and Roberts, R. D. (2012). What we know about emotional intelligence: How it affects learning, work, relationships, and our mental health. MIT press. 


\title{
Relationship of HR Practices and Career Path: a Perspective of Accounting Studies
}

\author{
Rizwan Ullah Khan ${ }^{1}$ \\ ${ }^{1}$ International Islamic University Islamabad, Pakistan
}

\begin{abstract}
The purpose of this paper was to investigate those factors which influence accounting students in selecting their career paths alongside graduation. In the current study, non-probability purposive sampling was used, in order to collect data, there are two sources namely primary and secondary we used, primary source to distribute questionnaire. The questionnaire was distributed among 530 male and female students that are enrolled in universities in different provinces as well as from capital city of the country also included at Pakistan, 470 filled questionnaires were collected while 67 were found incomplete/unusable mean not to specify gender, age, etc. and so were excluded from the analyses, therefore, 470 were used for analysis. A response rate of $89 \%$ approximately was achieved.

In the findings of this paper we include two new variables in the model to examine which factors are significantly influencing accounting students preferences towards their career paths. The two new variables source of information from media and recruitment and selection are taken, both have positive relation with career path. This paper is the first study undertaken in Pakistan to successfully provide a new dimension to accounting students in choosing their career paths upon graduation.
\end{abstract}

\section{Introduction}

In August 1992 The Institute of Certified Public Accountants of Pakistan (ICPAP) was established as an association with the goal to contribute world class preparing in Management, Finance, Auditing, Corporate and Tax Laws and Accounting to students working officials and experts in Pakistan. The Institute of Certified Public Accountants of Pakistan (ICPAP) aims to drive the Certified Public Accountant (CPA) program with a best in class course plan and educational modules. Consistently, the Certified Public Accountant (CPA) program got solid response from a wide cross region of understudies, capable and working authorities, starting at now there are 1700 CPAs who viably completed the CPA Program of ICPAP and got the CPA Charter. Today the ICPAP is the principle voice of corporate accountants and money related officials. Individuals comprise of experts, for example, CFOs, CEOs, budgetary controllers and others in the field of corporate accounting and money related administration. (Hutaibat, 2012) clarified that the absence of inclination for administration accounting could be because of the absence of formal instruction in administration accounting. The Past writing uncovered that other impacting component utilizing the social psychological profession hypothesis incorporate characteristic moti-

\footnotetext{
${ }^{1}$ Corresponding author.

Email: rizwanhayat1989@gmail.com
}

http:/ / www.jbrc.pk

vation, extrinsic motivation, outsiders impact and career introduction.

Organization of Chartered Accountants of Pakistan (ICAP) is an expert accounting body in Pakistan. Starting at July 2016, it had 8,819 individuals working in and outside Pakistan. On 1 July 1961 the establishment was set up to coordinate the calling of accounting in Pakistan. It is a legal free body set up under the Chartered Accountants Ordinance 1961. With the vast improvement in the calling, the CA Ordinance and Bye-Laws were reconsidered in 1983. The course of ICAP includes a mix of hypothetical instruction and handy preparation which run instantaneously for a time of 3.5 years and gives an understudy with information, capacity, abilities and different qualities required of an expert accountant.

Vysotskaya et al. (2016) utilized an explanatory path to deal with show that accounting can be spoken to as an arrangement of conditions comprehended through fundamental framework polynomial math capacities. They recommended that such a portrayal of the accounting framework might be useful in widening students' understanding and conceptualization of accounting as a numerical framework. There are some reasons in accounting programs, battle to enlist students and therefore the reasons go from impression of the extent of bother to price, dread of mathemat- 
ics, or perhaps absence of topic learning (Schneider and Sheikh, 2012). In any case, the availability of accounting specialists stays level, however the interest for accountants, particularly bonded open accountants (CPAs), keeps on increasing (Briggs and He, 2012).

New body changes to expand examination with the Enron Bankruptcy in 2002 and therefore the financial emergency in 2008 have created wild requests (Akers et al., 2014). The increasing range of resigning accounting personnel and therefore the inadequate range of accounting specialist popping into sympathy toward specialists and profound organizations (Devi et al., 2012). These worries square measure one thought mimicking the career paths being picked by the deficient range of accounting graduates, because the interest for accounting students increment, the amount of enrolees has confronted a downhill pattern, that prompts associate far more than work for the people who decide the knowledgeable course of accounting (Suddaby et al., 2015). The amount of accounting graduates with a specialization in examining, assembling, cost, and alternative business territories is two hundredth additional noteworthy in distinction with totally different business degrees (Plumlee and Reckers, 2014).

Around $25 \%$ of accounting students come up short in view of disgraceful direction, and half change their specialization, which leaves roughly $25 \%$ of the underlying populace of students selected in an accounting project to be accessible as future representatives (Suddaby et al., 2015). Little has been done to address the difficulties going up against the accounting scholarly group and in addition the accounting profession all in all (HassabElnaby et al., 2012). Declining recruitment in accounting programs (Hopper, 2013), expanded weakening among accounting educators (Davis and Jones, 2014), and accounting understudy motivation sorts (Hopper, 2013), all have been already inspected without giving determination of the issue of the absence of accounting staff to address the necessities of organizations. Also, there is a shortage of exact research on the status and patterns of accounting educational modules, recruitment, and conveyance of learning substance (Apostolou et al., 2013). Unless there is powerful data on the clear qualities of college projects on accounting, the projects that report problems on accounting are set to be guaranteed toward disappointment (Apostolou et al., 2013).

The goal of this review is to distinguish components which impact accounting students in picking their profession paths upon graduation, experimental review from Pakistan. Essentially, accounting students have numerous options as far as professional success upon their graduation is concerned. For example, they may progress into zones of budgetary accounting, tax assessment, administration accounting, reviewing, fund, and so on. This review incorporates add up to five factors in which one profession path is needy vari- able and four free factor, though, two taken from past review, in particular intrinsic motivation, career presentation and staying two new factors representative prerequisite and wellspring of data from media in the model to figure out which components are huge and affecting accounting students' inclination towards their career paths. Other than that, instructive organizations may profit by this review as subject educators or scholarly instructors may utilize the discoveries of this review to help students in their profession decisions. On top of that, expert accounting bodies may likewise profit as the discoveries could give a premise to them to outline their part recruitment techniques.

\section{Literature Review}

\subsection{Social Cognitive Career Theory}

Social Cognitive Career Theory (SCCT) by Lent et al. (1994) clarifies the communication among individual, logical, and behavioral factors in the process, in which professional interests and career decisions create, and an individual holds on in her or his career. A few reviews have analyzed the center socio-intellectual factors of the model and have discovered solid support for suggestions identified with these factors (Ali et al., 2005; Lent et al., 2003, 2005). The present review tests a few SCCT suggestions by exploring diverse schools and Universities students' profession decisions crosswise over Pakistan (2017) topics and reaches out past reviews by including individual and logical factors in the SCCT show and looking at the model fit crosswise over sexual orientation gatherings and college setting.

A couple of years after the fact, some experimental research upheld this interrelation that with higher self-adequacy, there is a change of result desires (Fouad and Smith, 1996; Lent et al., 2008). An audit of accounting training writing by Watson et al. (2007) incorporates an examination of learning styles and innovation (Tho, 1994). For instance, McDuffie and Smith (2006) address the specific utilization of a review announcing framework as a showing help and its effect on students' execution. Schleifer and Dull (2009) consider metacognition as a critical part of self-managed learning and in this manner having potential as a learning aptitude or credit that can serve to enhance accounting instruction and execution. Fox and McDonald (2010) consider the effect of an understudy peer-coaching program on first year students' scholastic execution, while Jones and Wright (2010) broaden past work by joining the impact of intellectual style and the utilization or nonutilization of two adaptations of a hypertext learning help and their connection on understudy execution in Advanced Financial Accounting.

As clarified by Chantara et al. (2011), SCCT includes three essential perspectives, in particular: self- 
adequacy, result desires and objectives. Self-efficacy alludes to a particulars confidence about his or her abilities to perform a strategy, which is identified with profession accomplishment (Ng et al., 2017). People with solid feeling of self-efficacy will for the most part place extraordinary exertion in finishing assignments, in spite of the troubles they experience. Result desires, then again, allude to the convictions on the future outcome after a specific conduct is performed (Chantara et al., 2011; $\mathrm{Ng}$ et al., 2017). In conclusion, objectives are characterized as a man's assurance to choose particular results of learning or execution. The organization of objectives speaks to a basic system, which includes the strategy which a man exercise his or her selfstrengthening.

\subsection{Career Path}

A career path is the unfaltering advancement an individual makes in his or her profession. A man's profession path may include one employment or a progression of jobs. The accounting profession has seen critical and huge moves in the course of the most recent years, for example, testing moral quandaries, emotional results for those occupied with false revealing, expanded directions, and changes in announcing principles. These elements can have an impact on those turning into an accounting major and also the elements that influence their decision of different jobs in the field. The argument behind this that graduates of accounting picked their path of profession by implication, jeopardizes the manageability in the field of accounting as a study of the program (Urbano et al., 2015). In light of an investigation of accounting assistants, Tong et al. (2008) found that individual job fit influences accounting students' career choices (considerably more than impression of individual association fit). Comparable research using the idea of fit has been done in advertising instruction in light of an expressed need to enhance the enrolling procedure for deals students (Agnihotri et al., 2014). Like earlier work, their outcomes showed that accounting students/experts tend to display detecting and judging qualities, recommending they focus on data getting through their faculties (as opposed to searching for examples) and like having things chosen instead of remaining open to new data (Swain and Olsen, 2011).

The influence and freedom of the accounting profession means that the viable authorization of accounting models (Ball et al., 2003). As per Joseph et al. (2012), an individuals career path could likewise be affected by the individual characteristics of the people. The ICAP resolved to manage the instruction, preparing and examination of its students keeping in mind the end goal to guarantee that a recently qualified Chartered Accountant can keep on being certainly. Being prepared to attempt work, requesting qualities and abilities ex- pected of a contracted accountant and being capable, with appropriate acceptance, rapidly to get any extra accounting aptitudes required for specific errand in broad daylight hone, industry, trade or somewhere else.

From 1994 a Pre-entry Proficiency Test (PPT) was acquainted to decide the reasonableness of hopefuls before being enlisted as Trainee Students/Full Time Students. PPT was required for all contestants with the exception of the individuals who were absolved from PPT however later when new arrangement was presented in 2014; it was totally barred from the course.

There appear to be numerous hypotheses with reference to why the discoveries of Madsen (2014) study were blended, however one steady contrast amongst accounting and different business projects is the compensation received by accounting graduates has stayed solid in respect to the compensation received by different business degrees, which stays static (Swanson and Creed, 2014). The earnest mindfulness was fundamentally more in the accounting field basic component for those who are non-accountant, high limit of understudies than prudent job prospects and high netting idle (Pan and Perera, 2012). Students' whittling down fall in programs of accountings was one of the difficulties in taking care of the yearly want of graduates in the accounting (Kruglanski et al., 2012). Thus, researchers retained endeavors to discover approaches to handle this test (Byrne et al., 2012). With a specific end goal to see how students can be held, a few variables identified with maintenance should be examined. Hindrances that may impact maintenance of understudies accounting incorporate motivation (Apostolou et al., 2013; Bagley et al., 2012; Byrne et al., 2012; Curtis, 2011; Jairam and Kahl Jr, 2012; Pan and Perera, 2012; Upton and Arrington, 2011) identified attributes by Curtis (2011), scholarly setting given by the school (Byrne et al., 2012; Curtis, 2011; Danino et al., 2013), and social components (Byrne et al., 2012; Danino et al., 2013). Each of these maintenance variables are talked about with regards to accounting graduates career path decisions.

\subsection{Intrinsic Motivation}

Students for the maximum part observe two remarkable types of motivation: intrinsic and extrinsic (Bagley et al., 2012). Intrinsic motivation is desire to prepare or accomplish to some degree since one exactly requires and takes feeling or stems motivation from undertaking it (Byrne et al., 2012). Intrinsic motivation is most ordinarily described as "helping out its own particular sake,". All the more as of late, Marriott and Marriott (2003) found that as students advance through their degrees, real enthusiasm for account diminishes. Tan and Laswad (2006) additionally found that students deciding for an accounting ma- 
jor were impacted by their enthusiasm for accounting and were sure about contemplating accounting. Conversely, non-accounting majors saw accounting as an exhausting scholarly major. Depicted as a natural process which individuals perform for interior reasons or for their own look of nervousness, intrinsic motivation is more predominant in accounting graduates looking for a profession path in the scholarly world (Davis and Jones, 2014).

Past reviews have additionally highlighted the connector between level of premium and the nature of learnedness and scholarship results of college students (Entwistle and Waterston, 1988; Ramsden, 2003). Given these association, students intrinsically inspired by contemplating accountancy would probably draw in with the substance in a way of life that mirrors the furtherance of building complex levels of comprehension of accounting ideas (Mladenovic, 2000). Discoveries found that intrinsic motive can emphatically influence students' career paths. Scholarly person inclines toward accounting essentially in light of the fact that accounting is intriguing. The students are likewise sure about getting great outcomes and are dependent on numbers and figures. These variables had intrinsically propelled students to study accounting. The intrigue/pleasure scale is considered as a self-report measure of characteristic motivation and the main scale that evaluates intrinsic motivation (Self-assurance hypothesis, 2016). Intrinsic motivation includes the inclination to seek after a scholastic errand in light of activity, be psychologically occupied with the undertaking by centring consideration, and endeavour to comprehend the subject by taking part in critical learning (Jairam and Kahl Jr, 2012).

An individual must have an intrinsic motivation to take in all the vital aptitudes expected to play out an undertaking to wind up plainly skilled and accordingly, intrinsically roused people can support understudy learning and accomplishment superior to outwardly propelled people (Jairam and Kahl Jr, 2012). Another past review directed by $\mathrm{Ng}$ et al. (2017) indicated sentiments and discernment towards the accounting profession have positive and huge impact towards career choice in accounting students. Then again, as per Adeleke et al. (2013), identified variables which included bent and mentality are appeared as huge elements of identity in the advance of profession intrigue. Subsequently, this prompts the theory that:

$H_{1}$ : There is a positive relationship between intrinsic motivation and career path.

\subsection{Career Exposure}

There is by all accounts general agreement in the writing that earlier introduction assumes an essential part in modelling goals (Zapkau et al., 2017, 2015). Tak- ing after (Krueger, 1993) four sorts of such presentation are ordinarily analyzed: (a) past encounters (b) family introduction; (c) close contacts with individuals (companions and relatives) occupied with accounting studies; and (d) related involvements in work in little or youthful firm. Most generally inquired about are the initial two sorts of presentation and since they are most applicable to our examination we might introduce the key discoveries beneath.

This exploration generally depends on quantitative examination in view of extensive date sets like Flash Eurobarometer Survey on accounting investigations of the University Spirit Students' Survey. Relatives, especially guardians move toward becoming good examples for the more youthful era furnishing them with motivation, learning, motivation, help to give the more youthful era a chance to characterize their self-idea (Gibson, 2004), additionally support and direction (Nauta and Kokaly, 2001).

Nonetheless, solid parental desires may now and again prompt clashing circumstances and settling on profession choices by students troublesome (Leung et al., 2011; Murphy and Lambrechts, 2015). On a basic level, the family condition impacts all career choices - work, autonomous expert action open administration, scholastic profession or the entrepreneurial course (Whiston and Keller, 2004). Nonetheless, in the last case the effect is especially solid and multidirectional (De Wit and Van Winden, 1989; Tognazzo et al., 2016). Coordinate presentation in the guardians' accounting studies is a proficient method for increasing important hands on experience which is not typically accessible for those not being conceived in families (Parker and Van Praag, 2012).

In this review, career introduction alludes to students' presentation to profession related data. As indicated by Ghani et al. (2009), most accounting students pick up career presentation through expert accounting bodies. Ghani et al. (2009) remarked that it is critical for students to be presented to the path of an accountant's job and what sort of profession it offers. With more prominent presentation on profession related data, one can settle on better choice in their career decision. Various reviews in the accounting training, writing, it was found that the majority of students acquired their profession introduction amid their review in the colleges via their scholastics by Miller and Wager (1971) and Erkut and Mokros (1984). Further gathering of studies proposed that students frequently picked up the information about the accounting profession from their families, companions and selection representatives (DeZoort et al., 1997).

$\mathrm{H}_{2}$ : There is a positive relationship between career exposure and career path. 


\subsection{Source of Information from Media}

Today's growing example of using new correspondence progressions has extended the potential results for how people can send and get information. With not a lot of points of confinement on the kind of prospecting that might be endeavored, online systems administration examination is as often as possibly associated with examples in 'gigantic data'. There is no obvious purpose of repression to the amount of messages that might be gotten or the estimations of society that might be investigated: "we no longer need to pick between data size and data significance. We can think revise bearings molded by, billions of social expressions, experiences, messages, and associations" (Manovich, 2011) (pp. 462-463). There are elite prerequisites about what this kind of research may draw in specialists to do (Goldin, 2010), however without creative work practices expected to set the foundations by finding what is open in the message, working with the industrious surges of trades is presumably going to stay testing and outside the compass of generally analysts. Information searching that it is the media which is such one development which seems extended use as it is one of the sources of information (Pepitone, 2010). For Instance, web based systems administration are being used to search for information about honest to goodness focuses that might be capable life and also singular life related, for instance, surrendering and hovering to-the minute information (Sutter, 2010). As this Seat Report prescribes "Society of people use online social instruments to assemble information, share stories, and look at concerns" Fox, (2011, p. 5).

Khan et al. (2016) detailed the consequences of an online study finished by students enlisted in a firstyear accounting course at four Australian colleges with respect to their utilization of media for scholarly purposes. Facebook was the essential online networking outlet utilized by the students. Overall, students revealed investing as much energy in media every week as they spent on learning exercises. An extensive bit of the students showed that they utilized media for scholarly purposes, in spite of the fact that document sharing (e.g., notes, past exam inquiries, and answers to practice exams) was the essential scholastic reason recognized. A few students revealed utilizing online networking for finishing assignments or ventures with colleagues. The creators found a noteworthy connection between GPA (self-announced by the students) and the utilization of online networking for scholastic purposes.

The sorts of data proposed in the chief section of this paper share no short of what one thing in like path: they all take course of action with uncertain conditions highlighted by potential hazard. As a rule, when helplessness addresses danger, folks successfully participate in information gathering pursuing (Brashers et al., 2000; Spence et al., 2006). In any case, nearby standard sorts of media, more present by source of media dynamically available for information pursuing. One sort of channel that gives various chances to this explanation behind existing is the Web. Investigation alludes that public use the Web in search for information about crises (Spence et al., 2006). All the more starting late, internet organizing has given another and possibly viable stage for people to use in search for such information.

$\mathrm{H}_{3}$ : There is a positive relationship between source of information from media and career path.

\subsection{Recruitment and Selection}

Each one of the frameworks and paths which are used as a piece of system of recruitment are when in doubt in a general sense surveyed in this exploration. For the determination of the representatives, every affiliation uses particular paths and frameworks for decision. Each one of the theories, techniques and strategies which are used as a piece of method of enrolment, will be analysed in a general sense, for the accomplishment of an affiliation, now both inside and outside frameworks are being used by the relationship in the selection methodology. Without a doubt, a diligent test confronting the accounting profession keeps on being the recruitment of top notch representatives who are a solid match for jobs in the accounting field (Dalton et al., 2013).

Newman and Lyon (2009) pointed the ordinary necessities for making huge pool for determination of the representatives is Job Analysis. For recruitment handle get ready work examination is the underlying stride. As demonstrated by Dalton et al. (2013) giving promotions for purge jobs is a standard methodology to find the right pool of hopefuls. Davidson et al. (2007) discussed the challenges that effect the contracting in associations, it was an examination facilitated by Equa Terra and studied more than 150 open portion specialists from United States to focus their business sharpens. Kaplan et al. (2004) recognized a couple of issues that incite terrible work decisions; most of them were deadness in masterminding, achieving poor determination of representatives in light of poor business examination. Nyangaresi et al. (2013) stressed on the point that in this forceful world, affiliations need to pick capable and adept individuals remembering the true objective to make and create as an affiliation. Khan et al. (2011) examined open division of Bangladesh and recognized HR at workplaces is feeble especially the branch of recruitment and determination. The HR division does not do suitable job examination, which prompts poor expected arrangement of duties and in this path the issue of getting the right plausibility for the work as authentic job examination is not done in 
that capacity prompts issue of recruitment and choice in the all-inclusive community part affiliations. Khan et al. (2011) asked about how HR sharpens out in the open territory of Pakistan, which is amazingly extraordinary. He recognized the importance of HR practices and choosing the ideal individual for the work. The investigation shed light on exact job examination for picking the right probability for the right business, which was completely neglected out in the open region of Pakistan as showed by his revelations. He, moreover said that choice of the representatives should be done according to the necessity of the job.

$\mathrm{H}_{4}$ : There is a positive relationship between employees recruitment and selection with career path.

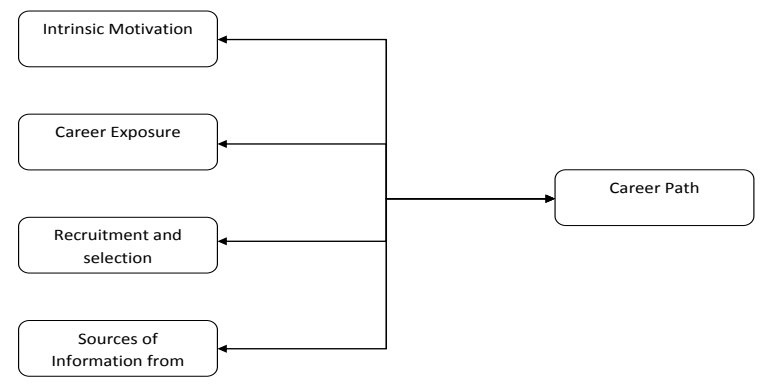

Figure 1: Framework

\section{Methodology}

\subsection{Sample and Procedure}

In the current study, non-probability purposive sampling was used. We used primary source to collect data through survey method. The questionnaire was distributed among 530 male and female students that are enrolled in universities in different provinces as well as from capital city of the country. 470 filled questionnaires were collected while 67 were found incomplete/unusable. A response rate of $89 \%$ approximately was achieved. Before submitting the survey, the entire particular were fully elaborated to the respondents in preliminary procedure to create convenience in filling the questionnaires and achieve relevant data. The respondents demographic are given in the following table according their response percentage. The respondents consist of $223(47.4 \%)$ females and $247(52.6 \%)$ males. Most of the respondents are around 19-21 years old, 22-24 years old, and above 25 years old at $34.3 \%, 32.8 \%$ and $33.0 \%$ respectively. There are 105 respondents $(22.3 \%)$ in the first year of the degree programme, respondents in the second year are $128(27.2 \%)$ and third year number at $118(25.1 \%)$ and lastly in the fourth year students respondent are 119 $(25.3 \%)$. More than half of the respondents do not have family or friends who are accountants. Close to half of the respondents have indicated that the accounting programme was their first choice.

\subsection{Instruments}

Intrinsic Motivation was measured using five construct from Odia and Ogiedu (2013), Career exposure measured from Hutaibat (2012), Career Path from Yusuf (2011) both have five items, Source of Information from Media (TV, Radio, Magazine, Newspaper, Internet) and Recruitment and selection from Kolvereid (1996). Each item used a five-point Likert scale, ranging from strongly disagrees, disagree, neutral, agree, to strongly agree. Cronbachs alpha value of the questionnaire was 0.76 , which satisfies the minimum criteria of 0.60 Hair et al. (1998). Thus, our construct measures are considered to be reliable and we can proceed with further analysis.

\section{Results}

The current study used Reliability, descriptive statistics, and regression tests in order to analyze the data. The present study uses structural equation modelling (SEM) that allows for the simultaneous estimation and testing of the relationships of pursuit. In SEM causal processes are represented by a series of structural equations that can be mannequin graphically to aid in conceptualizing a theoretical model. For the design of this study, pupil was asked to identify their age, gender, and the level of study mean first,second,third and fourth year of the accounting studies.Evidence from the questionnaire survey can then be used mainly for description, explanation or hypothesis testing.

\subsection{Correlation Matrix}

The main objective of the study is to analyze the effect of various factors on Career Path decision making. Several tests have been applied; summary of the results is given in Table 4.1 reports means, standard deviations, and Pearson correlations among studied variables. Hierarchical regression modeling (HRM) was employed to test our hypotheses.

Table 4.1 presents descriptive statistics and correlations among the variables. The variable have a significant positive relationship when $(\mathrm{P}<0.05)$ and negative correlation between variables when the $(\mathrm{P}>0.05)$.In addition, the reliability test was also analysed in which the Cronbach alphas are $(0.733,0.601$, and 0.640$)$ for each variable in the Table 4.1.

Table 4.1 shows the results of correlation matrix. As per the findings, Career path is positively and significantly correlated with intrinsic motivation $\left(0.1859^{*}\right)$, 
Table 4.1: Means, Standard Deviation, coefficient of Correlation and Reliability

\begin{tabular}{|c|c|c|c|c|c|c|c|}
\hline & & & 1 & 2 & 3 & 4 & 5 \\
\hline Variables & Mean & St.D & & & & & \\
\hline Career Path & 2.6856 & .97284 & - & & & & \\
\hline Intrinsic Motivation & 3.7127 & .55496 & $0.185^{*}$ & $(0.733)$ & & & \\
\hline Career Exposure & 3.7841 & 44548 & $0.005 \mathrm{~ns}$ & $0.277^{*}$ & $(0.601)$ & & \\
\hline Recruitment \& Selection & 3.5480 & 64050 & $0.143^{*}$ & $0.535^{*}$ & $0.351^{*}$ & $(0.64)$ & \\
\hline Source of Information from Media & 3.488 & .88235 & $0.201^{*}$ & $0.321^{*}$ & $0.284^{*}$ & $0.145^{*}$ & $(0.712)$ \\
\hline
\end{tabular}

$n=470$, alpha reliabilities are presented in parentheses. ${ }^{*} P_{j} 0.05, n s=$ not significance

Table 4.2: Linear Regression

\begin{tabular}{lccc}
\hline \multicolumn{4}{c}{ Career Path } \\
\hline Model & Unstandardized Coefficients B & $\mathbf{t}$ & Sig. \\
\hline (Constant) & 3.103 & 18.866 & $.000^{* *}$ \\
Gender & .022 & .446 & .656 \\
Age & .391 & 2.648 & $.009^{*}$ \\
Intrinsic Motivation & .141 & 3.532 & $.027^{*}$ \\
Career Exposure & .209 & 4.144 & $.000^{* *}$ \\
Recruitment \& Selection & .279 & 2.811 & $.052^{*}$ \\
Source of Information from Media & .347 & 2.576 & $.003^{*}$ \\
R Square & .036 & & \\
Change R Square & .218 & & \\
\hline
\end{tabular}

a. Dependent Variable: career path

$P$ value $<.05$ significant

recruitment and selection $\left(0.143^{*}\right)$ and Source of information from media $\left(0.201^{*}\right)$. Whereas, the correlation between career path and career exposure is non significant. Similarly, instrinsic motivation positively correlated with career exposure at $0.277^{*}$, as well as with recruitment and selection and source of information at $0.535^{*}$ and $0.321^{*}$, respectively. Table also shows the reliability of each variable, which is well within acceptable range.

\subsection{Regression Analysis}

The first hypothesis of this study states that there is a positive relationship between intrinsic motivation and career path. So based on the result presented in the Table 4.2, we found a significant positive impact between intrinsic motivation and career path $(\mathrm{r}=0.535, \mathrm{p}=$ $0.000)$. The second hypothesis stated that there is significant positive correlation between career exposure and career path. ( $\mathrm{r}=0.351, \mathrm{p}=0.000)$. the third hypothesis of this study proposed that There is a positive relationship between source of information from media and career path so according to presented result in Table 4.1 that there is direct positive significant correlation between recruitment and career path $(\mathrm{r}=0.143, \mathrm{p}=0.020)$.

The first hypothesis of our study was that there is a positive relationship between intrinsic motivation and career path. So according to the results presented in Table 4.2 that overconfidence has a significant positive impact on intrinsic motivation and career path $\beta=0.141$ and $\mathrm{P}<0.05)$. So, intrinsic motivation has strong and significant relation with career path (Jairam and Kahl Jr, 2012; Ng et al., 2017). According to previous studies we suggest that there are strong positive relation. Similarly, where $\beta=.209$ and $\mathrm{p}<.05$, due to these results we suggested that career exposure has green signal for connection with career path,leading to acceptance of hypothesis two as well (Parker and Van Praag, 2012; Tognazzo et al., 2016). Hypothesis three suggests that there is a positive relationship between employees recruitment and selection and career path so according to the result presented in the Table $4.2, \beta=.279$ and $\mathrm{p}$ $<.05, \mathrm{H}_{3}$ has been accepted. As per hypothesis four, there is a positive relationship between source of information from media with career path; the regression results indicate that $\beta=.347$ and $\mathrm{p}<.05$, lending support to the hypothesis four as well (Khan et al., 2016). Similarly, the change in $\mathrm{R}$ square (.218) indicates that $22 \%$ variation dependent variable is caused by independent variables, further substantiating the results.

Ultimately, based on the study results and lending support from the previous studies as well, we conclude that in current study, independent variables have a positive relation with their dependent variable. 


\section{Conclusion and Discussion}

This review is valuable to the expert accounting bodies in planning their methodologies for individuals' recruitment. Be that as it may, the consequences of this review might be constrained in two paths. To start with, this review was led on a solitary private organization in Pakistan. Second, the information was gathered utilizing comfort examining strategy. The outcomes, consequently, can't be summed up to all accounting students in Pakistan. In any case, the discoveries of this review may at present be valuable to the expert accounting bodies as the private college picked initiates an enormous number of accounting students in Pakistan every year for its accounting program. From the discoveries of this review, a lack of qualified cost bookkeepers as specified before could be illuminated by making enthusiasm for auxiliary school students before they go into tertiary training. Proficient bodies, for example, Certified Public Accountant (CPA) and ACCA may consider giving more talks, courses and occasions to enhance auxiliary school students enthusiasm towards administration accounting. Furthermore, talks, courses and occasions on the administration accounting profession could likewise be given to tertiary students to open them to career paths in the administration accounting zone. With more career introduction towards the administration accounting career, accounting students enthusiasm towards administration accounting career could be additionally made strides. The after effects of this review could be further enhanced. To control variables, for example, year of program or/and age, could be incorporated to further improve the model. It might likewise be intriguing for future research to extend its degree to look at different business students who chose not to major in accounting.

\section{References}

Adeleke, M. S., Binuomote, M. O., and Adeyinka, M. (2013). Determinants of students academic performance in financial accounting among senior secondary school leavers in oyo state. International Journal of Business and Management Invention, 2(5):48-59.

Agnihotri, R., Bonney, L., Dixon, A. L., Erffmeyer, R., Pullins, E. B., Sojka, J. Z., and West, V. (2014). Developing a stakeholder approach for recruiting top-level sales students. Journal of Marketing Education, 36(1):75-86.

Akers, M. D., Giacomino, D., Courtney, K., and Johnson, O. (2014). A profile of top performers on the uniform cpa exam.

Ali, S. R., McWhirter, E. H., and Chronister, K. M. (2005). Selfefficacy and vocational outcome expectations for adoles- cents of lower socioeconomic status: A pilot study. Journal of career assessment, 13(1):40-58.

Apostolou, B., Dorminey, J. W., Hassell, J. M., and Watson, S. F. (2013). Accounting education literature review (20102012). Journal of Accounting Education, 31(2):107-161.

Bagley, P. L., Dalton, D., and Ortegren, M. (2012). The factors that affect accountants' decisions to seek careers with big 4 versus non-big 4 accounting firms. Accounting Horizons, 26(2):239-264.

Ball, R., Robin, A., and Wu, J. S. (2003). Incentives versus standards: properties of accounting income in four east asian countries. Journal of accounting and economics, 36(1-3):235270 .

Brashers, D. E., Neidig, J. L., Haas, S. M., Dobbs, L. K., Cardillo, L. W., and Russell, J. A. (2000). Communication in the management of uncertainty: The case of persons living with hiv or aids. Communications Monographs, 67(1):63-84.

Briggs, G. P. and He, L. (2012). The 150 credit-hour requirement and cpa examination pass ratesa four year study. Accounting Education, 21(1):97-108.

Byrne, M., Flood, B., Hassall, T., Joyce, J., Montaño, J. L. A., González, J. M. G., and Tourna-Germanou, E. (2012). Motivations, expectations and preparedness for higher education: A study of accounting students in ireland, the uk, spain and greece. In Accounting Forum, volume 36, pages 134-144. Elsevier.

Chantara, S., Kaewkuekool, S., and Koul, R. (2011). Selfdetermination theory and career aspirations: A review of literature. institutions, 7:9.

Curtis, S. M. (2011). Formative assessment in accounting education and some initial evidence on its use for instructional sequencing. Journal of Accounting Education, 29(4):191-211.

Dalton, D. W., Buchheit, S., and McMillan, J. J. (2013). Audit and tax career paths in public accounting: An analysis of student and professional perceptions. Accounting Horizons, 28(2):213-231.

Danino, N., May, L., and Mitchell, N. (2013). Reprogramming 1st year students: An action research case study. UCLan Journal of Pedagogic Research, 4.

Davidson, G., Lepeak, S., and Newman, E. (2007). The impact of the aging workforce on public sector organizations and mission. International Public Management Association for Human Resources.

Davis, H. E. and Jones, K. (2014). The impact of changes in accounting program retention policies. AND ACCOUNTING, page 31 .

De Wit, G. and Van Winden, F. A. (1989). An empirical analysis of self-employment in the netherlands. Small Business Economics, 1(4):263-272.

Devi, S. S., Kumar, R., and Raju, S. K. (2012). Partnering with practice for accounting education: Evidence from the pacific. 
DeZoort, F. T., Lord, A. T., and Cargile, B. R. (1997). A comparison of accounting professors' and students' perceptions of the public accounting work environment. Issues in Accounting Education, 12(2):281.

Entwistle, N. and Waterston, S. (1988). Approaches to studying and levels of processing in university students. British Journal of Educational Psychology, 58(3):258-265.

Erkut, S. and Mokros, J. R. (1984). Professors as models and mentors for college students. American Educational Research Journal, 21(2):399-417.

Fouad, N. A. and Smith, P. L. (1996). A test of a social cognitive model for middle school students: Math and science. Journal of Counseling Psychology, 43(3):338.

Fox, S. C. and McDonald, A. G. (2010). Chemical and thermal characterization of three industrial lignins and their corresponding lignin esters. BioResources, 5(2):990-1009.

Ghani, E. K., Said, J., Nasir, N. M., and Jusoff, K. (2009). The 21st century accounting career from the perspective of the malaysian university students. Asian Social Science, 4(8):73.

Gibson, D. E. (2004). Role models in career development: $\mathrm{New}$ directions for theory and research. Journal of Vocational Behavior, 65(1):134-156.

Goldin, I. (2010). World wide research: Reshaping the sciences and humanities. MIT Press.

Hair, J. F., Anderson, R. E., Tatham, R. L., and Black, W. C. (1998). Multivariate data analysis. 1998. Upper Saddle River.

HassabElnaby, H. R., Dobrzykowski, D. D., and Tran, O. T. (2012). Applying the international medical graduate program model to alleviate the supply shortage of accounting doctoral faculty. Decision Sciences Journal of Innovative Education, 10(2):271-294.

Hopper, T. (2013). Making accounting degrees fit for a university. Critical Perspectives on Accounting, 24(2):127-135.

Hutaibat, K. A. (2012). Interest in the management accounting profession: accounting students perceptions in jordanian universities. Asian Social Science, 8(3):303.

Jairam, D. and Kahl Jr, D. H. (2012). Navigating the doctoral experience: The role of social support in successful degree completion. International Journal of Doctoral Studies, 7:311329.

Jones, S. H. and Wright, M. E. (2010). The effects of a hypertext learning aid and cognitive style on performance in advanced financial accounting. Issues in Accounting Education, 25(1):35-58.

Joseph, D., Boh, W. F., Ang, S., and Slaughter, S. A. (2012). The career paths less (or more) traveled: A sequence analysis of it career histories, mobility patterns, and career success. MIS Quarterly, pages 427-452.

Kaplan, R. S., Kaplan, R. E., Norton, D. P., Norton, D. P., Davenport, T. H., et al. (2004). Strategy maps: Converting intangible assets into tangible outcomes. Harvard Business Press.
Khan, T., Kend, M., and Robertson, S. (2016). Use of social media by university accounting students and its impact on learning outcomes. Accounting Education, 25(6):534-567.

Khan, W., Ahmed, A. A. A., and Neogy, K. (2011). Recruitment, selection issues and challenges in public sector: Bangladesh case study.

Kolvereid, L. (1996). Prediction of employment status choice intentions. Entrepreneurship Theory and practice, 21(1):47-58.

Krueger, N. (1993). The impact of prior entrepreneurial exposure on perceptions of new venture feasibility and desirability. Entrepreneurship theory and practice, 18(1):5-21.

Kruglanski, A. W., Bélanger, J. J., Chen, X., Köpetz, C., Pierro, A., and Mannetti, L. (2012). The energetics of motivated cognition: a force-field analysis. Psychological review, 119(1):1.

Lent, R. W., Brown, S. D., and Hackett, G. (1994). Toward a unifying social cognitive theory of career and academic interest, choice, and performance. Journal of vocational behavior, 45(1):79-122.

Lent, R. W., Brown, S. D., Nota, L., and Soresi, S. (2003). Testing social cognitive interest and choice hypotheses across holland types in italian high school students. Journal of Vocational Behavior, 62(1):101-118.

Lent, R. W., Brown, S. D., Sheu, H.-B., Schmidt, J., Brenner, B. R., Gloster, C. S., Wilkins, G., Schmidt, L. C., Lyons, H., and Treistman, D. (2005). Social cognitive predictors of academic interests and goals in engineering: Utility for women and students at historically black universities. Journal of Counseling Psychology, 52(1):84.

Lent, R. W., Sheu, H.-B., Singley, D., Schmidt, J. A., Schmidt, L. C., and Gloster, C. S. (2008). Longitudinal relations of self-efficacy to outcome expectations, interests, and major choice goals in engineering students. Journal of Vocational Behavior, 73(2):328-335.

Leung, S. A., Hou, Z.-J., Gati, I., and Li, X. (2011). Effects of parental expectations and cultural-values orientation on career decision-making difficulties of chinese university students. Journal of Vocational Behavior, 78(1):11-20.

Madsen, P. E. (2014). Has the quality of accounting education declined? The Accounting Review, 90(3):1115-1147.

Manovich, L. (2011). Trending: The promises and the challenges of big social data. Debates in the digital humanities, 2:460-475.

Marriott, P. and Marriott, N. (2003). Are we turning them on? a longitudinal study of undergraduate accounting students' attitudes towards accounting as a profession. Accounting education, 12(2):113-133.

McDuffie, R. S. and Smith, L. M. (2006). Impact of an audit reporting expert system on learning performance: a teaching note. Accounting Education: an international journal, 15(01):89-102. 
Miller, G. A. and Wager, L. W. (1971). Adult socialization, organizational structure, and role orientations. Administrative Science Quarterly, pages 151-163.

Mladenovic, R. (2000). An investigation into ways of challenging introductory accounting students' negative perceptions of accounting. Accounting Education, 9(2):135-155.

Murphy, L. and Lambrechts, F. (2015). Investigating the actual career decisions of the next generation: The impact of family business involvement. Journal of Family Business Strategy, 6(1):33-44.

Nauta, M. M. and Kokaly, M. L. (2001). Assessing role model influences on students' academic and vocational decisions. Journal of Career Assessment, 9(1):81-99.

Newman, D. A. and Lyon, J. S. (2009). Recruitment efforts to reduce adverse impact: Targeted recruiting for personality, cognitive ability, and diversity. Journal of Applied Psychology, 94(2):298.

Ng, Y.-H., Lai, S.-P., Su, Z.-P., Yap, J.-Y., Teoh, H.-Q., and Lee, H. (2017). Factors influencing accounting students career paths. Journal of Management Development, 36(3):319-329.

Nyangaresi, M., Nejeru, W., Mutavi, T., and Waithaka, N. (2013). Recruitment and selection process: A case of city council of nairobi, kenya. Review of Contemporary Business Research, 2.

Odia, J. and Ogiedu, K. (2013). Factors affecting the study of accounting in nigerian universities. Journal of Educational and Social Research, 3(3):89.

Pan, P. and Perera, H. (2012). Market relevance of university accounting programs: Evidence from australia. In Accounting Forum, volume 36, pages 91-108. Elsevier.

Parker, S. C. and Van Praag, C. M. (2012). The entrepreneur's mode of entry: Business takeover or new venture start? Journal of Business Venturing, 27(1):31-46.

Pepitone, J. (2010). Twitter users not so social after all. CNNMoney. com.

Plumlee, R. D. and Reckers, P. M. (2014). Lessons not learned: Why is there still a crisis-level shortage of accounting ph. ds? Accounting Horizons, 28(2):313-330.

Ramsden, P. (2003). Learning to teach in higher education. Routledge.

Schleifer, L. L. and Dull, R. B. (2009). Metacognition and performance in the accounting classroom. Issues in Accounting Education, 24(3):339-367.

Schneider, G. P. and Sheikh, A. (2012). Addressing the shortage of accounting faculty: Using non-tenure-track positions. Academy of Educational Leadership Journal, 16(1):1.

Spence, P. R., Westerman, D., Skalski, P. D., Seeger, M., Sellnow, T. L., and Ulmer, R. R. (2006). Gender and age effects on information-seeking after 9/11. Communication Research Reports, 23(3):217-223.
Suddaby, R., Saxton, G. D., and Gunz, S. (2015). Twittering change: The institutional work of domain change in accounting expertise. Accounting, Organizations and Society, 45:52-68.

Sutter, J. (2010). Texts, maps battle haiti cholera outbreak. Retrieved October, 31:2010.

Swain, M. R. and Olsen, K. J. (2011). From student to accounting professional: A longitudinal study of the filtering process. Issues in Accounting Education, 27(1):17-52.

Swanson, D. J. and Creed, A. S. (2014). Sharpening the focus of force field analysis. Journal of change management, 14(1):28-47.

Tan, L. M. and Laswad, F. (2006). Students' beliefs, attitudes and intentions to major in accounting. Accounting Education: an international journal, 15(2):167-187.

Tho, L. M. (1994). Some evidence on the determinants of student performance in the university of malaya introductory accounting course. Accounting Education, 3(4):331-340.

Tognazzo, A., Gubitta, P., and Gianecchini, M. (2016). " my old and my new family"-the impact of family relationships on students' entrepreneurial intentions: An italian study. International Review of Entrepreneurship, 14(4).

Tong, S. T., Van Der Heide, B., Langwell, L., and Walther, J. B. (2008). Too much of a good thing? the relationship between number of friends and interpersonal impressions on facebook. Journal of computer-mediated communication, 13(3):531-549.

Upton, D. R. and Arrington, C. E. (2011). Race matters: whether we know it, or like it, or not: implicit racial attitudes and their effect on accounting-based, balanced scorecard performance evaluations.

Urbano, C., Zhang, Y., Downey, K., and Klingler, T. (2015). Library catalog log analysis in e-book patron-driven acquisitions (pda): A case study. College $\mathcal{E}$ Research Libraries, 76(4):412-426.

Vysotskaya, A., Kolvakh, O., and Stoner, G. (2016). Mutual calculations in creating accounting models: A demonstration of the power of matrix mathematics in accounting education. Accounting Education, 25(4):396-413.

Watson, S. F., Apostolou, B., Hassell, J. M., and Webber, S. A. (2007). Accounting education literature review (20032005). Journal of Accounting Education, 25(1-2):1-58.

Whiston, S. C. and Keller, B. K. (2004). The influences of the family of origin on career development: A review and analysis. The Counseling Psychologist, 32(4):493-568.

Yusuf, M. (2011). The impact of self-efficacy, achievement motivation, and self-regulated learning strategies on students academic achievement. Procedia-Social and Behavioral Sciences, 15:2623-2626.

Zapkau, F. B., Schwens, C., and Kabst, R. (2017). The role of prior entrepreneurial exposure in the entrepreneurial process: a review and future research implications. Journal of Small Business Management, 55(1):56-86. 
Zapkau, F. B., Schwens, C., Steinmetz, H., and Kabst, R. (2015). Disentangling the effect of prior entrepreneurial exposure on entrepreneurial intention. Journal of Business Research, 68(3):639-653. 


\title{
Exploring the Unexplored Local Own Source Revenue: A Case Study of TMA Murree
}

\author{
Sidra Asif ${ }^{1}$, Abdul Waheed ${ }^{* 2}$, Malik Asghar Naeem ${ }^{3}$, \\ ${ }^{1,2,3}$ National University of Sciences E Technology (NUST), Islamabad, Pakistan
}

\begin{abstract}
Collection of local own source in a decentralized economy is a huge challenge for town administrations in developing countries. The resultant of which is poor service delivery and infrastructural management due to collapses of local economic conditions.In the light of worldwide developed and developing countries scenario this study comprehends the ideology of collection of local own source revenue in Town Municipal Administration Murree and its aftermaths on the local economy.This study has explored all the major sources of revenue in Town Municipal Administration Murree and has identified a clear relation and dependency of internal and external sources of revenue. The research determined that the Town Municipal Administration is mostly dependent on property taxes and financial grants from the provincial government to meet its needs. For unexplored local own source revenues introduction of the property tax in the form of capital gain tax and infrastructure development tax as a major part of the internal own source revenues. For external own source revenue compensation in the form of environmental degradation tax due to positive externalities of the areas tourism capacities should also be introduced. There is no collaboration in the public and private sector for reinforcement of the local economy. It has also been concluded that there is no integrated policy for taxation and revenue generation in the local government.
\end{abstract}

\section{Introduction}

Governments are usually run in a three tier systems globally.Pakistans case is no different; it comprises of Federal government, Provincial government, and Local/Municipal Government (Anjum and Ahmad, 2001). Every government, under given jurisdiction, holds the authority and responsibility to generate and exploit funds efficiently. However efficiency can be a subjective term but in broader perspective it infers to balancing demand supply curves, cash inflows outflows and revenue and expenses.

\subsection{Issues of Local Governments}

The rapid increase in urbanization has created serious trials for local government administrations in both developed and developing countries in terms of environmental contamination, traffic congestion, and lack of affordable housing, poor waste collection, flagging infrastructure and income polarization (Behrens and Robert-Nicoud, 2009). Local governments are required to provide basic infrastructural facilities and appropriate service delivery to their cities. Importantly, the newly rising problem of rapid urbanization has caused urban sprawl marking it to become the biggest challenge for municipalities. It creates difficulties for the

*Corresponding author.

Email: drwaheed@nit.nust.edu.pk local administration to provide means of equal distribution of resources and services to the local residents(Cohen, 2006). An ideal model for service delivery must have a mechanism in which all the services being provided by any local government should be paid back as benefits from those services.However, despite the fact that local communities are willing to pay for the service delivery, they are unable to receive the standard of living they are paying for (Otegbulu and Johnson, 2011). Worldwide studies have been conducted in different local governments to identify the problems in municipal finance.

A case study of municipality of Kllokot, Albania has been encountered during this research which has the similar problem of collection of own source revenue in a local government. The municipality of Kllokot has been very limited in their planning for Own Source Revenues, therefore the department for budget and finance has looked into the possibility of introducing additional sources of revenue and estimation of the capacity building of these sources for revenue generation. The municipality of Kllokot did not have a full property database and had no regular update of the properties levied to the local residents; it was therefore suggested that means to update the property database will enhance collection of local own source revenue. Kllokot can also potentially receive good revenues from con- 
struction permits, geodesic plans and measurements, field inspections of construction sites. Identification of donors and strategic development in terms of tourism and taxation has also led to improvement in the municipal revenue condition (Coudert et al., 2010).

There is a positive relationship between internally generated revenue and infrastructural development in Lagos State Government. It has also been observed that the various methods of generating internal revenue are the enforcement of tax personnel, contribution, and creating awareness to the public and if these are administered correctly they can generate more revenue for the country. The sources of revenue that are significant such as taxes, licenses, fines and fees, grants, financial aids and loans should be reconstructed and re-engineered through public awareness, keeping systematic manner of collection (Adenugba and Ogechi, 2013). The solution for local governments to meet their responsibilities lies largely in the extraction of non-tax revenues and collection of designated local taxes (Pillay, 2015). Local taxes, user charges and fees are a significant local government revenue source, whereas shared taxes are uncommon and borrowing is an insignificant source of finance in most developing SubSaharan African countries (Cohen, 2006). User fees are applied in order to ensure that the municipal finances are being enhanced by the people as per their willingness to pay for any service delivery (UN-HABITAT, 2005).

The local government reform programme (LGRP) in Tanzania has contributed to positive changes in local authorities provision of basic services to the public, enhanced capacity for financial management and revenue enhancement, improved governance, including accountability and responsiveness of the local government (Fjeldstad and Semboja, 2000). The same situation prevails in local governance of Pakistan; Punjab in particular. Many problems have been arising in the decentralized economic revenue collection method. The resultant of which is poor service delivery and infrastructural management due to collapses of local economic conditions. Keeping in view all the worldwide developed and developing countries scenario the current study captures the ideology of collection of local own source revenue in Town Municipal Administration Murree and its effects on the local economy.Generating revenue has been one of the integral problems in any level of governance. For the same reason, the research was to explore major sources of revenue for TMA Murree and identify the existing financial situation. By identification of the source further recommendations of administrative nature have also been proposed. This has led the research to find out dependency of own source revenue of TMA with local economy and then explore the link between internal and external local own source revenue.

\section{Methodology}

Mixed method research methodology has been adopted in this study to create a triangulation of qualitative and quantitative data. For the purpose of research, local economy was segregated into formal and informal economy, focusing on scanning out the sectors under formal tax net from the sectors of economy that has no levied taxes and is not examined by the higher authorities. It is also pertinent to mention here that the activities taking place in an informal economy are not registered in the government economic labels and hence not included in the gross national product or gross domestic product. This type of economy has no rules or fixed wages. People working on daily wagers, hawkers and street vendors, home based entrepreneurs, cobblers, etc. all belong to an informal economy. Therefore, to gauge the financial condition of TMA Murree only formal economy was considered and then revenue sources were assessed to evaluate additional sources of revenues.

The primary data required for this research were collected through the questionnaire based field survey from local community and close observation of collection methods, policy formulations within the TMA and means to implement and monitor these policies. Data and information about socioeconomic and demographic characteristics of the local community were collected through field survey.The sample size designated for this survey consisted of 100 randomly selected households of aforementioned localities of Murree.Basic component of the research was to gather data regarding financial situation of TMA Murree and explore the local own sources which generate revenue for the town. This was carried out through collection of secondary data from the TMA and also by conducting interviews from the people at stake of the revenue collection. Interviews were conducted with the Officers of TMA Murree to understand the method of collection of own source revenue, to get an insight of five year budget and to identify major own source income pattern of the TMA. Furthermore, structured interview of official of Finance department in Punjab Local Government Board office, Lahore to comprehend the process of budgeting and allocation of funds to the case study area from the government department. The data obtained from field surveys including questionnaires and interviews have been analyzed using Statistical Package for the Social Sciences (SPSS). Descriptive statistics techniques have been used to provide central tendency of the data and to explain relationship between different study variables to identify the current financial situation of TMA. Correlation analysis was performed to identify linkages among internal and external sources of income, as well as budget with one another and with the yearly expenditure. 


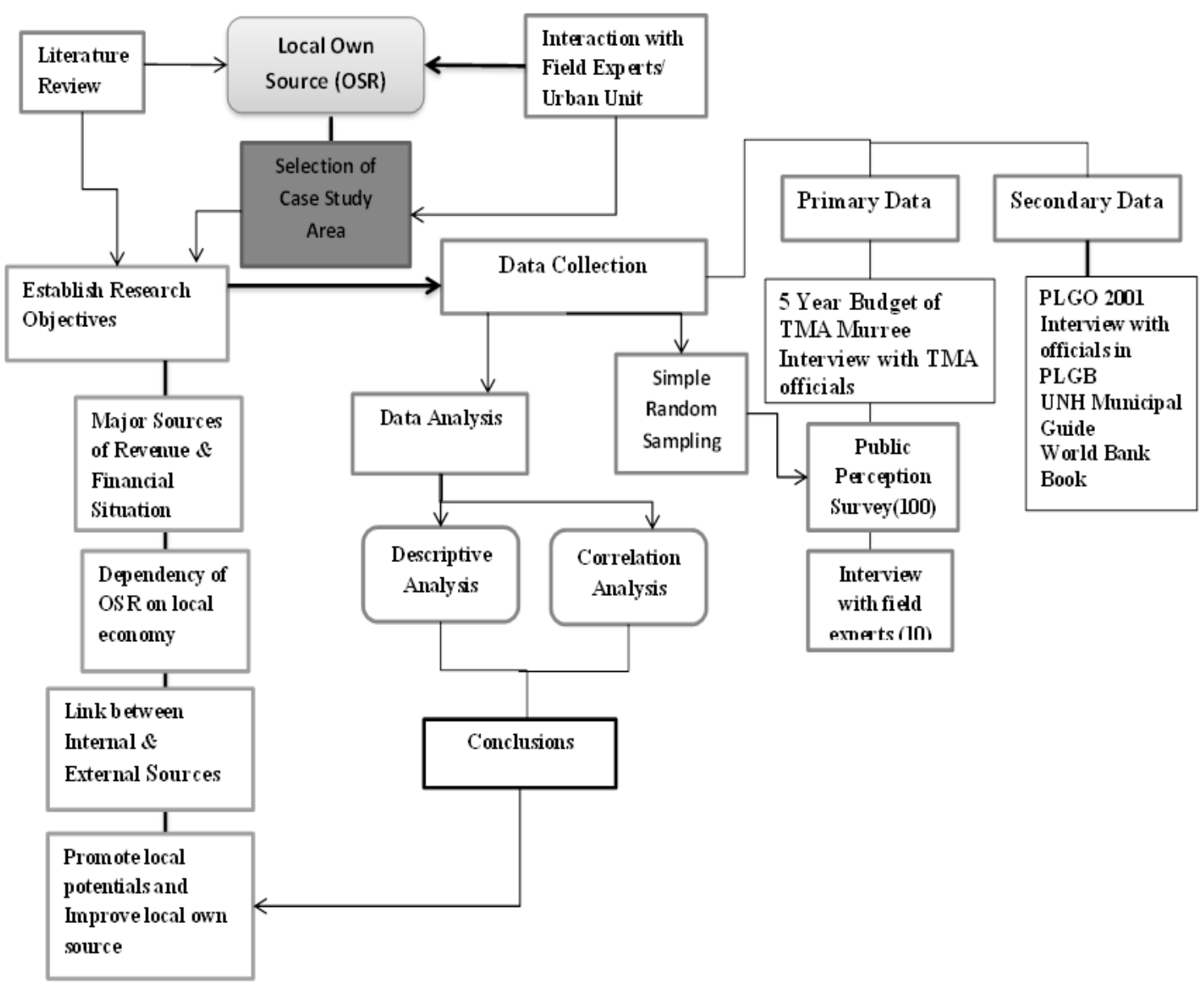

Figure 1: Research Methodology

\section{Results and Discussion}

The results of socioeconomic and demographic analysis of community characteristics show that number of male members in the households is greater than female members $(74 \%)$. However, the result revealed the fact that a large number of households $(80 \%)$ have only one earning member. A large number of the families $(39 \%)$ comprised of 2 male members while only a few $(15 \%)$ have one male member. A few families $(23 \%)$ had more than two male members in their households. Similarly the ratio of female members varied in the households and only a small number of families $(13 \%)$ comprised of one female member, while a huge quantity $(87 \%)$ consisted of two or more than two female members, thus depicting the ratio of female population in the area. The factors highlighted in the socioeconomic characteristics of the residents of TMA are discussed in detail as under. If we examine Table 3.1 we see a variating trend in the type of employment among the residents mostly varied from self-employed to private jobs $(65 \%)$. And only a very few of the residents / bread-earners (35\%) were involved in government jobs or miscellaneous activities (such as caretaker, watchman, shop workers, salesman, etc.)

The monthly income of households has also been identified through different income groups. Almost half of the total sample (49\%) consists of low income group that falls below the average income of 20,000 PKR which depicts urban poverty in the residential units of Murree. Likewise, the other half of the respondents $(48 \%)$ consisted of income groups falling from 20,000 PKR to 60,000 PKR which is considerably a middle income group. This variation also depended largely upon the locations where surveys were conducted thus the trends were different in different areas of the city. The results although indicate that most of the population comprises of lower income class. The ownership trend in the residential areas of Murree has also been discussed in the Table 3.1 where it was observed that more than half of the population (53\%) owned the houses they resided in. Most of the people (42\%) lived on rent. It was also observed that although Murree is a tourist area but only a few (5\%) of people were residing temporarily in the household units. The residents have been settling in Murree for a very long time and a large 
Table 3.1: Socio Economic Characteristics

\begin{tabular}{|c|c|c|c|c|}
\hline Subject Characteristics & $\begin{array}{c}\text { Frequency } \\
\text { (f) }\end{array}$ & $\begin{array}{c}\text { Percentage } \\
(\%)\end{array}$ & Mean & SD \\
\hline Gender of Respondent & 100 & 100 & & \\
\hline Male & 68 & 68 & & \\
\hline Female & 32 & 32 & & \\
\hline Type of Family & 100 & 100 & 1.11 & 0.314 \\
\hline Nuclear & 89 & 89 & & \\
\hline Joint & 11 & 11 & & \\
\hline Single Person & 0 & 0 & & \\
\hline Family Size (Number of Male Members) & 100 & 100 & 1.31 & 0.563 \\
\hline $1-3$ & 74 & 74 & & \\
\hline $4-6$ & 21 & 21 & & \\
\hline $7-10$ & 5 & 5 & & \\
\hline More than 10 & 0 & 0 & & \\
\hline Number of Earning Members & 100 & 100 & 1.2 & 0.402 \\
\hline 1 & 80 & 80 & & \\
\hline 2 & 20 & 20 & & \\
\hline 3 & 0 & 0 & & \\
\hline \multicolumn{5}{|l|}{ More than 3} \\
\hline Employment Type of Earning Members & 100 & 100 & 2.35 & 0.968 \\
\hline Government Job/Army & 18 & 18 & & \\
\hline Self Employed/Shopkeeper & 46 & 46 & & \\
\hline Private Job & 19 & 19 & & \\
\hline Misc. & 17 & 17 & & \\
\hline Monthly Income & 100 & 100 & 1.65 & 0.757 \\
\hline$<20,000 \mathrm{PKR}$ & 49 & 49 & & \\
\hline 20,000-40,000 PKR & 40 & 40 & & \\
\hline 40,000-60,000 PKR & 8 & 8 & & \\
\hline Above 60,000 PKR & 3 & 3 & & \\
\hline House Ownership & 100 & 100 & 1.57 & 0.742 \\
\hline Owned & 53 & 53 & & \\
\hline Rented & 42 & 42 & & \\
\hline Leased & 5 & 5 & & \\
\hline \multicolumn{5}{|l|}{ Other } \\
\hline Stay Period & 100 & 100 & 2.32 & 0.839 \\
\hline$<5$ years & 24 & 24 & & \\
\hline $5-15$ years & 20 & 20 & & \\
\hline $15-25$ years & 56 & 56 & & \\
\hline More than 30 years & 0 & 0 & & \\
\hline
\end{tabular}

number of residents (56\%) have been living in Murree over 20 years. Only a few $(20 \%)$ have been residing in their residential areas for a period ranging from5-15 years and $29 \%$ for less than 5 years.

\subsection{Major Sources of Revenue as per PLGO 2001}

A local government needs to fulfil its role to provide basic amenities in its rural and urban areas in a resilient manner. It has been observed that scarce finances are a major reason of inefficient performance by the local government or any of its concerned TMA. To resolve this issue the fiscal decentralization of local governments was formulated in 2001 and different functions were assigned to the Town Municipal Administrations through Punjab Local Government Ordinance (PLGO) 2001. PLGO 2001 recommends the collection of local own source revenue collection by a town administration which helps it in generating finances from its local sources and taxes levied on the residents in return of utilities, property, etc. This in turn promotes better and efficient financial framework. And only a strong financial government can promote efficient service delivery. The budget allocations and col- 
lection of revenue were major part of the PLGO 2001 and hence it was clearly defined that what kind of taxes and revenues have to be generated by a local government in its area of jurisdiction. These different sources of revenue in TMA Murree from internal and external base are described in the Table 3.2.

\subsection{Dependency \& Distribution of Own Sources}

The income pattern of each own source for a period of five financial years has also been scrutinized from 2009-2010 to 2013-14. The following figure 2 highlights the major sources of income in TMA Murree from 2009 to 2014. This trend helped realize the major sources of income on which the Town Municipal Administration depends. From Figure 2 it is highlighted that during scrutiny of the 5 year income trend it was observed that $21 \%$ of the revenue was being generated from property taxes which is $2 \%$ more than designated in the budget for the same period. It also embarked the fact that there was great potential in revenue generation from this source. However it was also observed that $20 \%$ of PFC had been reserved for the TMA but the same had been utilized up to $26 \%$ which was more than the share of the TMA.

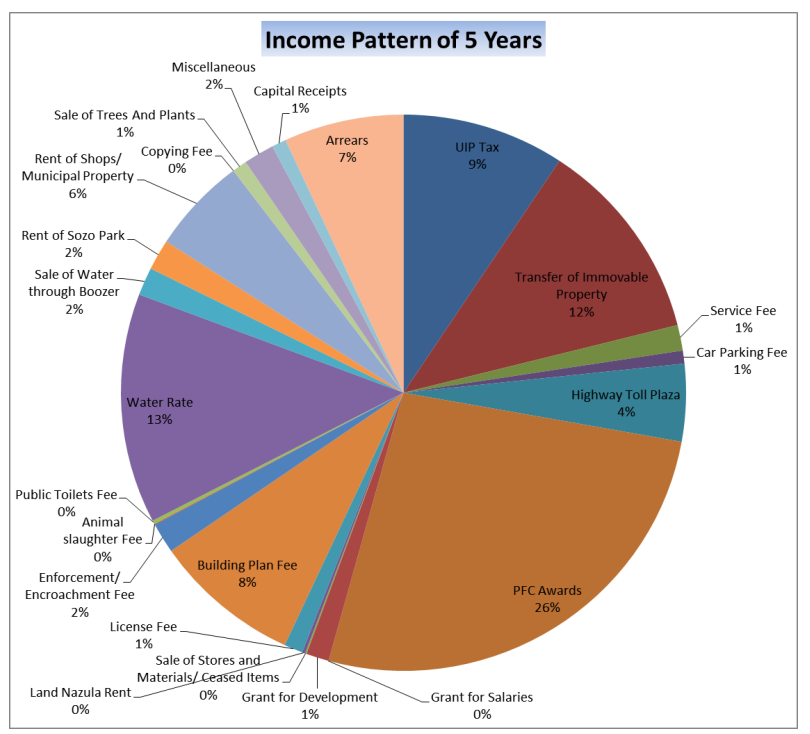

Figure 2: Income Patterns of Past 5 Years in TMA Murree

The Figure 3 describes the total budget trend of 5 years studied to conduct this research. According to this trend a total of $19 \%$ is fixed every year to be collected through property taxes. $20 \%$ is fixed to be collected as PFC grants from the government and $49 \%$ from remaining sources.

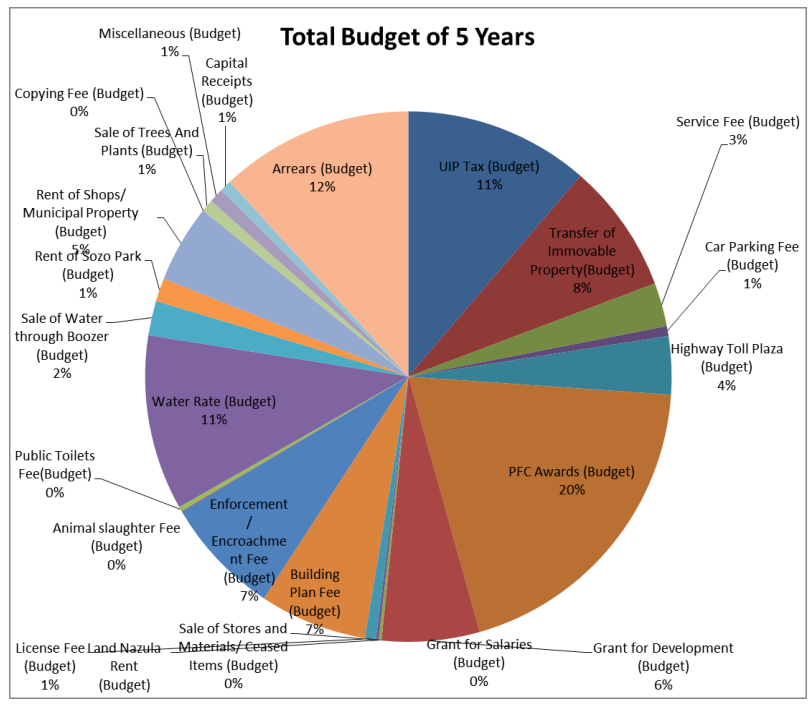

Figure 3: Budget of Past 5 Years in TMA Murree

\subsection{Trend Analysis of Own Source Rev- enue}

Since local economies are of two kinds that are observed in most countries (a) Formal Economy and (b) Informal economy, therefore the revenues are also divided into both these sectors. The formal sector of economy incorporates all kinds of jobs with regular wages. This type of economy involves income sources on which taxes are likely to be paid. People working in different organizations, public sector, schools, bans, etc. all belong to formal economy. Consequently, the external sources of revenues do not really contribute to formal economy, whereas the informal sector of economy has no levied taxes and is not examined by the higher authorities. It is also important to point out that the activities taking place in an informal economy are not registered in the government economic labels and hence not included in the gross national product or gross domestic product. This type of economy has no rules or fixed wages. People working on daily wagers, hawkers and street vendors, home based entrepreneurs, cobblers, etc. all belong to an informal economy. This segregation of documented and undocumented economy is a major concern because when the external entities are being benefitted by the services provided by the local government they are actually contributing to the informal economy of the TMA. On the other hand, in result of the degradation of the infrastructure, government is called upon. The figure 4 shows dependency of own sources on the local economy. Four sources have been identified as major components of formal economy of the local government. These sources are property tax, water rate, building plan fees and rent of municipal properties and shops.

The income generated through these sources is 
henceforth directly reliant upon the local economy. The bar chart in figure 4 reveals that for the year 2009-2010 $13 \%$ of the total income generated was through collection of UIP and TTIP taxes, $11 \%$ was collected through water rate, $10 \%$ through building plan fee and $4.3 \%$ through rent of shops and municipal properties. For the year 2010-2011, it shows that $13 \%$ of the total income for the year was collected through property taxes, $4.9 \%$ through building plan fee and $6.9 \%$ through rent of properties. For the year 2011-2012, 21.17\% of the total income was collected through Property Taxes, $14.6 \%$ through water rates, $7.9 \%$ through Building Plans and $4.9 \%$ by shop and municipal properties rent. For the year 2012-2013, 28\% of the total income was generated from UIP and TTIP taxes, $13 \%$ was collected from Water Rate, $1.49 \%$ was from Building Plan Fees and 6.1\% was collected from Shop Rents. 28\% income was generated from property taxes for the year 2013-2014, 12\% was through water rate, $15.5 \%$ through building plans and $5.9 \%$ from rent of properties.

There has been an increase in the property taxes over the years, the water rate has been somewhat constant for the 5 year income pattern, a massive rise and fall is identified in the building plan fee over the period of 5 years and rent has also been almost the same.

\subsection{Link between External and Internal Lo- cal Own Source}

Regardless of the decentralization of local economy and independent work environment as well as autonomous establishment of each TMA; a huge number of TMAs all over Punjab are mainly reliant on intergovernmental transfer (such as NFC or PFC Awards). This can be deliberated as the reason of inadequate attention to collection of local own sources and means to enhance revenue generation through local own source. However, it is also apposite to highlight the fact that these external sources may also be used to stimulate internally generated revenue through local own sources. The following correlation analysis highlights the link between external and internal sources of income in TMA Murree and also discovers whether the external sources/ grants have a positive or negative impact on the local own source. A Pearson product-moment correlation coefficient was computed to assess the relationship between these variables.

The Table 3.3 describes the correlation among internal and external sources of income as well as budget with one another and with the yearly expenditure.The expenditure trends and internally generated revenue has a positive correlation, where $r=0.976$. This shows that the correlation among these two variables is quite significant, as well as described by the correlation index they exhibit a strong correlation. This is further deliberated with the fact that the increase in expenditure of the TMA stimulates the means to generate more income through internal revenue sources. Similarly, a decrease in the internally generated revenue would cause a negative effect on the development and nondevelopment expenditures within the TMA. Furthermore, the expenditure has a negative correlation with income of external sources, where $r=-0.68$. As per the index of correlation, this represents a strong correlation but with a reverse effect on one another. It means that with the increase in external sources of income (PFC Awards in this case study) the spending on expenditure decreases. However, this study demonstrates that the PFC Award for each year have been nearly static for the past 5 years. And substantially there have been remarkable differences in the expenditure for each year hence justifying the negative correlation.

Table 3.2: Local Own Sources of Revenue in TMA Murree

\begin{tabular}{|c|c|c|c|c|}
\hline \multicolumn{3}{|c|}{ Internal Sources } & \multicolumn{2}{|c|}{ External Source } \\
\hline Land Based & Non-Land Based & Service Charges & $\begin{array}{l}\text { Government Aids/ } \\
\text { Grants }\end{array}$ & Capital Receipts \\
\hline UIP Tax & Car Parking Fee & Community Services & $\begin{array}{l}\text { Share from Highway } \\
\text { Toll Plaza }\end{array}$ & $\begin{array}{ll}\text { Cash Balances by } \\
\text { Local Government/ } \\
\text { Banks }\end{array}$ \\
\hline $\begin{array}{l}\text { Tax on Transfer of } \\
\text { Immovable Property }\end{array}$ & Water Rate & License Fee & PFC Awards & \\
\hline Building Plan Fee & Chair Lift Share & Public Latrines & Grant for Salaries & \\
\hline $\begin{array}{l}\text { Enforcement / En- } \\
\text { croachment }\end{array}$ & Animal Slaughters & $\begin{array}{l}\text { Water Sale through } \\
\text { Boozar }\end{array}$ & $\begin{array}{l}\text { Government Grant } \\
\text { for Development }\end{array}$ & \\
\hline Rent of Sops & Rent of Sozo Park & Copying Fee & & \\
\hline $\begin{array}{l}\text { Rent of Municipal } \\
\text { Property }\end{array}$ & $\begin{array}{l}\text { Sale of trees and } \\
\text { plants }\end{array}$ & & & \\
\hline Land Nazula Rent & Sale of Ceased Goods & & & \\
\hline & Misc. & & & \\
\hline
\end{tabular}




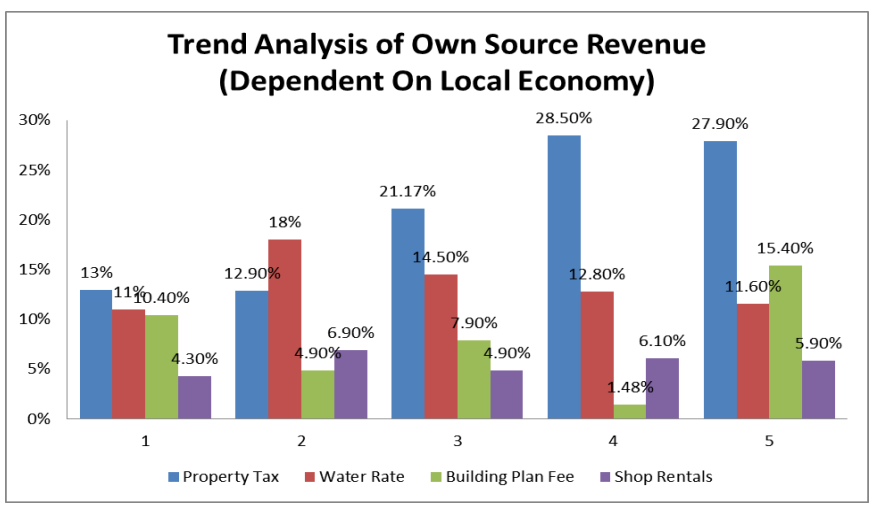

Figure 4: Trend Chart of Own Source Revenue (Dependent on Local Economy

Table 3.3: Correlation Matrix between Internal and External Sources

\begin{tabular}{lccccccc}
\hline Item & Mean & SD & (A) & (B) & (C) & (D) & (E) \\
\hline (A) Expenditure Trend & 1.34 & 4.65 & 1 & & & & \\
(B) Budget of Internal Sources & 1.28 & 6.09 & 0.033 & 1 & & & \\
(C) Budget of External Sources & 3.85 & 7.18 & -0.2 & 0.96 & 1 & & \\
(D) Income of Internal Sources & 7.63 & 1.27 & 0.976 & 0.19 & -0.61 & 1 & \\
(E) Income of External Sources & 3.67 & 5.83 & -0.68 & 0.56 & 0.68 & 0.2 & 1 \\
\hline
\end{tabular}

** Correlation is significant at the 0.01 level (2-tailed)

* Correlation is significant at the 0.05 level (2-tailed)

\section{Conclusion \& Recommendations}

The research determined that the TMA is mostly dependent on property taxes and financial grants from the provincial government to meet its needs.Most of the population belongs to low to middle income groups. The local people are unaware of the importance of taxation and method of collection of taxes.It was also observed during research that the general public is not satisfied with the working efficiency of the Town $\mathrm{Mu}-$ nicipal Administration. There is no collaboration in the public and private sector for reinforcement of the local economy. It has also been concluded that there is no integrated policy for taxation and revenue generation in the local government. The research conducted also led us to the conclusion that to improve revenue generation within the Town Municipal Administration, a few amendments in the overall service structure and financial obligations of the local government can be made. It has also been determined that most of the sources for own source revenue collection have not been reviewed or changed for a very long time and the process of its revision is time consuming and governmental in nature. It was observed that political involvement can also create difference in collection of revenue as local political leaders have an influence on the local people. In the instant research it has been concluded that selfsufficiency can be enhanced through improving the under explored sources of revenue and introducing some new unexplored sources of revenue to strengthen the economy at both and local and national level.

\subsection{Recommendations}

There is a need to balance the operating costs and expenditures on local government levels as well. This imbalance in TMA Murree could be due to a number of reasons but that was not of prime focus in this study, rather, we focused on identification of sources of revenues and based on that, we proposed new local own source revenues for TMA Murree. The following recommendations, if adopted, can resolve the financial imbalance of the local government in Murree. This will lead to economic prosperity administrative efficiency and social uplift in standards of living in TMA Murree. There are a few components that have been highlighted in the research as key factors for improvement of local own source in a TMA:

Public is unaware of the method of taxation and lags trust towards the local government. To rectify this situation hence awareness among the civilians is required.We must educate our taxpayers by providing proper awareness of the importance of taxation. Local council members must be included in the decision making of tax rates and annual budgets as they are well aware of the issues of public. Taxpayers must be registered with the concerned TMA for efficient payment of taxes and information distribution as and when re- 
quired.

An efficient policy must be made at all three tiers of government i.e. local, provincial and national level to improve the revenue generation. It is also important that the policies at all levels must be well integrated and coordinated. The revision and rephrasing of policies has to be done at two levels: inter-governmental and intra-governmental. The TMA should devise a proper management system to compute levied taxes as well as tax database. All stakeholders must be well coordinated and informed about the annual taxation methods as well as change in tax rates. The officials collecting revenue at municipal level must be well trained. With the inflation rates in the annual budget the tax rates should be revised by the government to keep an easy and acceptable tax return from the public.

An electronic system for levied taxes must be introduced. GIS and GPS mapping may also be incorporated with the electronic taxation system for efficient identification of all citizens/taxpayers. Online complaint registration system should be introduced, so that general public can communicate their problems to the government without any hindrance. PublicPrivate Partnership should be introduced in collaboration with local government and concerned local municipality. Outsourcing of private firms (Albayrak, PHA and RWMC in Murree) along with the TMA officials can generate revenue for both the departments. Service based revenue such as service fee, license fee; animal slaughter fee, environmental protection fee, infrastructural development, etc. must be introduced through public-private partnerships. Staff in all the departments must be well aware of their area and jurisdiction and apt training of all the officials must be done after specific intervals of time for efficient working and results from all government and private departments. All the allied departments must be well coordinated. It is therefore necessary that combined workshops and training programs must be designed for all the departments. The most significant factor in improvement of the local own source revenue is the ability of the local government to be self-sufficient. To increase the local own source revenue of TMA Murree the globally adopted approach of linking the services provided to the collected revenue should be adopted. Since everyone wants to see what they are paying for therefore in this way people would be more supportive to pay taxes for a particular service that would certainly be for their own individual and collective benefit.

The research determined that following sources of revenue are under explored within the city and hence efforts should be made by the TMA officials to improve revenue from these sources in collaboration with other departments; if and where required.

- Building Plan Fees

- Rent of Recreational and Commercial Properties
- License and Animal Slaughter Fee

- Fee for Public Services

Similarly, new sources can also be introduced in the TMA as per its potential of generating revenue. The following unexplored sources should be proposed henceforth for improvement of local own source revenue. In the light of the existing property tax situation, property tax in the form of capital gain tax should be imposed because even if the property is not being traded local government is incurring some costs to maintain the area around that property. This compensation on property not being traded for a period of more than, for instance, 10 years should be paid to the local government according to the percentage of capital gain across the property. Any property held or traded has some utilities built around it by the local government to develop that area. That infrastructure development tax could include addition of local parks, street lights, roads, water supplies, sewage systems, etc. into the area. The increase in value of ones property due to increase in infrastructure facilities built by the government should be compensated by the property holder.There should be a compensation fee for the environmental degradation of the area by each and every person coming from outside the jurisdiction of the TMA. Utilizing services built by local government like water supplies, sewerage systems, roads etc. should be compensated for local people by the non-local people to the extent of damage done to the whole system (Fruits, 2015).

\subsection{Future Prospects}

This research can be extended by taking on board the local government and run real time micro systems for particular areas in Murree. The micromodel project would provide proper insight to the functionality and efficiency of the proposed recommendation on real time scales. Furthermore, other areas in Pakistan can be identified with similar geo-socio-economic conditions, where the model can be implemented as well.

\section{References}

Adenugba, A. A. and Ogechi, C. F. (2013). The effect of internal revenue generation on infrastructural development. a study of lagos state internal revenue service. Journal of Educational and Social Research, 3(2):419.

Anjum, Z. H. and Ahmad, N. (2001). New local government system: a step towards community empowerment?[with comments]. The Pakistan Development Review, pages 845867.

Behrens, K. and Robert-Nicoud, F. (2009). Survival of the fittest in cities: Agglomeration polarization, and income inequality. Cahier de recherche/Working Paper, 9:19. 
Cohen, B. (2006). Urbanization in developing countries: Current trends, future projections, and key challenges for sustainability. Technology in society, 28(1-2):63-80.

Coudert, V., Gex, M., et al. (2010). Credit default swap and bond markets: which leads the other. Financial Stability Review, 14:161-167.

Fjeldstad, O.-H. and Semboja, J. (2000). Dilemmas of fiscal decentralisation: A study of local government taxation in tanzania. In Forum for Development Studies, volume 27, pages 7-41. Taylor \& Francis.
Fruits, E. (2015). Impact of federal transfers on state and local own-source spending.

Otegbulu, A. and Johnson, O. (2011). The impact of jacuzzi bathtubs on house prices. Journal of Sustainable Development, 4(3):199.

Pillay, R. (2015). Value of contracting as an active purchasing mechanism of healthcare services: a South African case study. PhD thesis, University of Cape Town. 


\title{
Corporate Governance: Theory and Practice Impact of Corporate Governance on Firm Performance
}

\author{
Rizwan Khalid ${ }^{1}$, Tayyab Ali $^{2}$, Muhammad Usman Javed ${ }^{* 3}$, \\ 1,2,3 Riphah International University, Islamabad, Pakistan
}

\begin{abstract}
Corporate governance is one of most widely researched topics in the different fields of management sciences. Additionally, governance plays equal role in firm performance in all countries especially developing countries become more important like Pakistan which contain equal importance to be studied with in subject to developed countries as to be well known in governance values, moreover there is increased interest to observe impact of corporate governance on different dimensions of firm performance. The objective of this paper is to underlay the corporate governance theories and practices and we have studied and try to analysis the impact of corporate governance structure on firm performance. This is a descriptive type of study in which we analysis different studies as coded all studies as they may have different implications in developed countries but here they may have different results as in developing countries and Pakistan is different among other Asian countries because of number of reasons as discussed in introduction with respect to its governance structure. We also have find interesting results as from other empirical studies recently a part of Pakistan perspective research and having number of important implications with respect of changes need to be made in Pakistan's governance structure. Findings shows there is impact of corporate governance on firm performance and market performance of firm also been effected with governance style.
\end{abstract}

Key words: corporate governance, firm performance, C.G theories in practice.

\section{Introduction}

Corporate governance(C.G) is a system or a network which sets certain orders or rules laid down for firms to be controlled and directed (Cadbury Committee, 1992). The company is owned by different people and run by different people as we know there are multiple persons attached with companies known as stakeholders and they may be involved with direct and indirect interests, which are justified with certain attentions involved to the firms. This arises the need of corporate governance to understand those rules by which the companies work and act in safe side of interests added by people to the companies they are attached with and of those who lead it.

Corporate governance is the system which makes sure that the finance suppliers to the company are satisfied about their investments which they made in company. Corporate governance is the framework of rules which makes sure that the rights and interests of financiers are not manipulated by the leading managers of that company in which they investment. Corporate governance is a big system which is developed with and has been developing with the time and making contributions in performance of companies and other

*Corresponding author.

Email: usman.shanu123@gmail.com variables. Research shows that the firm which has been governed better so they may have better performance as their payout ratios, are higher than of those which have been badly governed; therefore, corporate governance actually plays important role in firm performance (Denis and McConnell, 2003; Yasser, 2011). Jensen and Meckling were two famous researchers who introduced agency problem under agency theory in 1976 and started new research domain of corporate governance (Jensen and Meckling, 1976). At that time the corporate governance researches were largely focused on governance matters related to U.S based firms. However, later the researches came which focus on corporate governance matters in different countries of the world circa 1990s. Initial studies were conducted in developed part of the world like Japan, U.K, Germany, which are the major world economies, but now the focus of such studeis has been shifting towards emerging economies of the world like Pakistan, India and China to understand and study the need and importance of corporate governance.

This paper will help to understand corporate governance history and new researches in developed and developing countries which will help to build understanding of corporate governance with aspect of the- 
ories and different dimensions which have been contributed in field of corporations rules and laws by which they work and be controlled.

\subsection{Corporate Governance an Overview in Pakistan}

In Pakistan the rules and the regulations by which the firms will act are framed in code of C.G governance in early 2002 by the security and exchange commission of Pakistan (SECP) in the corporate governance; reforms in Pakistan. This code was developed by the joint aspect of SECP and ICAP. All the listed corporations in Pakistan are required to follow the instructions of this code and have to act upon the given provisions. The companys ordinance 1984 and the companies act 2017 and banking companys ordinance 1962 also provide the framework of different companies and provisions of governance mechanism, which have to be followed by the companies working in Pakistan. Securities \& Exchange Ordinance;(1969) is the based securities (law) and gives rules for protection of firms and investors, etc. The Securities \& Exchanges Act; (1996) empowered (SECP) as the regulator of the Capital Market \& controller of the Corporate Entities, whereas State bank (SBP) has made different implications code for the listed and non-listed banks which are to be followed by financing institutions as well. There is a separate code of governance for insurance companies as well.

The basic rights of shareholders and creditors are protected in Pakistan as the following, incorporated by ruling authorities and laws:

- Registration of shares is made under Central Depository Committee (CDC) and is very secure.

- Shareholders have right to participate in Annual General Meeting of the company and ask any information from managers related to their interest.

- Directors are selected by votes and might be removed by special resolution passed by sitting or holding rights (voting) shareholders.

- Shareholders having $(10 \%)$ or more voting rights have to disclose their ownership to understand the internal structure of firm.

- There should'nt be more than $(75 \%)$ of executive directors in BODs to project the minority shareholders interest.

- The code favor the institutional investors to be representative for meetings of board.

Comparing India with Pakistan, actually Pakistan can generate better by just making good improvements in governance in its real economy and it has done before in difficult time when the economy was in down turn, (Improved Governance; Dawn, 2010). Cheema (2003) asserts that issues are not actually between higher management and shareholders in Pakistan as shown mostly in academic literature, but agency problem is between the large shareholders and the other small or we can say the minority shareholders. So security and exchange commission of Pakistan (SECP) is trying to improve and make effective implementations of governance mechanism legislature by collaboration with Asian Development Bank and World Bank and so they require major researches in Pakistan about corporate governance.

\subsection{Corporate Governance Theories}

\subsubsection{Agency Theory}

This theory was developed by Jensen and Meckling (1976). This theory was defined as the relationship between the principles and agents, such as shareholders and agents such as the company executives and managers. The shareholders are the owners or the principles of the firms and they hire the agents who are managers or employees and they perform the task for their firms (Clarke, 2004). The agents are expected to perform work in best interest of their principles but here comes the problem where the control and power are separated and interest may not always align so here the theory gives link of corporate governance where there is a need of such rules to control and govern the firms with their owner's best interest (Padilla, 2000); same thing confirmed by Ross (1973) and Davis et al. (1997). However the managers and owners have different view about the risk and returns, because the studies confirm that the owners may want high return so they will like to have projects with higher risk profile to increase the firm's value; whereas managers want low risk profile projects to invest by the shareholders to ensure continued income and play at safe side, therefore resulting in conflict of interest. Whereas, studies also confirm the agents are self-interested and also have opportunistic behavior so they design those compensations which provide agents or managers with efficient incentives which in turn maximize the shareholder value (Bayless, 2009; Bhimani, 2008; Buck et al., 2008; Conyon, 2014; Eisenhardt, 1989; Holmstrom and Milgrom, 1994; Murphy, 1999; Ozkan, 2011). So the agency theory gives view of check and balance type of governance style. e.g. chairman and CEO are two different people and board should be independent.

\subsubsection{Managerial Power Theory}

As explained above, the compensation plans should be aligned with company's interest and the owners of firms should make sure the compensations are in their best interest to make mangers work accordingly to not hold all power in their hand and 
many studies describe the payperformance relationships (Tosi et al., 2000; Van Essen et al., 2015). MPT theory is most well known among all other theories, according to MPT, if balance of the power shifts towards the managers who act as agents, so they will behave opportunistically and that is why the compensation plans give great importance to control the managers and not letting them behave opportunistically (Bebchuk and Fried, 2003). If the powers of CEOs will have increased, so the board of directors will also get influenced by CEOs and they will not perform their duties as well as they should be performed and for such power shifts control the corporate governance is there to not let the power shift in wrong way and to control the firms rules in which manner the CEOs will work and perform their duties so that's why the CEO duality is considered to be not so good for other shareholders. CEO duality means at the same time, the person is chairman of board as well as a CEO of same firm so he may have extra power and he will set his own compensation very high and enjoy on behalf of other shareholders (Core et al., 1999; Jensen, 1993). Many studies confirm the positive relation of CEO duality and compensation and MPT shows that CEO duality has negative relation with board dependence and positive relation with power shifts (Boyd, 1994; Brick et al., 2006; Conyon, 2014; Core et al., 1999; Fahlenbrach, 2008; Van Essen et al., 2015). This theory gives view of governance by controlling the CEO power based on pay and shows $\mathrm{CEO}$ and chairman are two different persons.

\subsubsection{Stewardship Theory}

Stewardship theory has the roots in psychology and sociology which was defined by Davis et al. (1997) as a steward protects and maximizes shareholders wealth through firm performance, because by doing, the stewards utility functions are maximized. According to this theory, the managers working in organizations are actually protecting the firms and making profit by increasing the value to the shareholders so unlike the agency theory, this theory shows the managers are stewards to the firms and they work with the goals of organizations. This theory argues that top managers are actually satisfied and happy with organizations achievement and become more and more motivated. Argyris (1973) said that the agency theory gives view of economic individual, which means the individuals work in their own interest but on other side the Donaldson and Davis (1991) argued that according to stewardship theory the managers should be empowered fully to act in best interest of shareholders and should perform autonomously all tasks given to them and this is also unlike with managerial power theory. Daily et al. (2003) said that the managers want to protect their reputation attached with their market worth so they perform functions in order to increase the firm's financial performance. Shleifer and Vishny (1997) argued that the managers return finances back to the financers as soon as possible, in order to re-enter the finance whenever they needed to enhance their market reputation. This model of stewardship can be seen in Japan because those are hard workers. Moreover, this theory suggests that $\mathrm{CEO}$ and chairman should be the same person to reduce the agency cost and to protect shareholder wealth and watch more closely about the firm affairs and this is how he will play greater role as stewardship and many past studies have shown that the return of firms will improve. This theory reflects the governance style as CEO duality and CEO \& chairman is one person so he can view and control better as he has more knowledge about operations of organization.

\subsubsection{Stakeholder Theory}

This famous theory was developed by Freeman in 1984, which represents the firm with the broad range of stakeholders and shows responsibilities of firm to its direct and indirect stakeholders. This is not formal unified theory but has broad research range like organization, law, ethics, economics and political sciences. This theory was defined as any group or individual who can affect or is affected by the achievement of the organizations objectives. Unlike the agency theory in which managers and owners are separate, the theorist of stakeholder theory suggest that managers, suppliers, business partners are in network, in a relation to serve the organization (Freeman, 1999). Sundaram and Inkpen (2004) argue that the stakeholders required the management's attention. Nevertheless, Clarkson (1995) said that a company is a system and it is running for stakeholders so it should require to increase wealth for its shareholders. Donaldson and Davis (1991) said that the stakeholder theory shows managerial decision making process and the interest of the stakeholders are valued but not dominated on one another. This theory gives view of governance by protecting all stakeholders interest and not only the owners.

\subsubsection{Resource Dependency Theory}

Stakeholder theory focuses on group of individuals benefits, while the resource dependency theory focuses on the resources provided by directors. This theory was given by Salancik and Meindl (1984) and defined as, "organization enters in relation with other organizations because it has relied on their resources to achieve its own goals. Hillman et al. (2000) argue that the resource dependency theory shows the role of directors in providing the resources to the firm by their linkages in the external environment. Johnson et al. (1996) argued that the resource theorists focus on appointment of such independent representative for the firm to whom the firm can have benefits and without 
him the firm has that benefits on high cost, for example, a person outside from the law firm and if he will be the independent director to the firm so he may give his advices on legal or organizational laws so it will be costless and if he may not be the director to the firm so his advices will be on high cost, which has to be paid by the firm. Daily et al, 2003 said as high as the resources of the firm are, better will be its performance. So this theory gives view of governance as we can say the performance of the firm is the direct function of its resources which is provided by the directors who may be independent.

\subsubsection{Transaction Cost Theory}

Transaction cost theory was first drived by Cyert et al. (1963) and later theoretically described and exposed by Williamson (1989). This theory views the firm as a big organization having a lot of people in it with different objectives and different views. A firm can determine the function of its price and its production so the unit of analysis in this theory is transaction cost. This theory argues that managers behave opportunistically and arrange firms transactions to their interests (Williamson, 1996). This theory is viewed as the part of corporate governance and agency theory, unlike the resource dependency theory, which argues that directors give resources and will be costless but transaction cost theory argues that cost will be raised when you wish something to be done from someone for you. e.g. directors to run business that you own. At first, this theory was viewed as the decision of make or buy in production. It represents the governance as the net effect from external and internal transaction cost.

\subsubsection{Ethics Theories}

Like other fundamental theories there are some ethics theories about corporate governance which represent the firm as an ethical person. e.g. social contract theory, which is defined as "the society as a series of social contracts between members of society and society itself" (Gray et al., 1996). Another theory which is famous in governance ethics is legitimacy theory, which was defined as a generalized perception or assumption that the actions of an entity are desirable, proper, or appropriate with some socially constructed systems of norms, values, beliefs and definitions (Suchman, 1995). Both theories argue that the firm gets permission to operate in society and it has some ethical obligations like CSRs.

\section{Literature Review}

Past studies comprehensively discussed the issue regarding the good corporate practices. The impacts of governance on the firm performance and profitability have been discussed and identified in literature review. The purpose of this study is to analyze the impact of corporate governance on the firm performance. In this study we have studied the effectiveness of corporate governance variable as "Internal" which has already been discussed by different researcher in their research study.

Internal corporate governance has the greatest impact on firm performance and the profitability and compensation as compared to other variables. Due to limited time frame we have only discussed few variables of corporate governance and created hypothesis in accordance with the view of developing country like Pakistan and compare other Asian countries like Japan and China and also keeping view from developed countries like U.S which has a best known and developed corporate governance, however this study has been done in many countries but Pakistan is one different country as per reasons given below.

- Family type of ownership in firms seems to be common in Pakistan than in Korea \& Japan. Similarly, while Chinese companies have more institutional owners concentration than in Pakistan.

- Chinese are likely to be different in companies as the State usually has more or high stakes in large corporations but in Pakistan concentrated family ownership is maintained by non-govt shareholders giving way to private-owned firms because of high family ownership in Pakistan.

- Legal law situation and political environment unstability in Pakistan, so weaker system results in poor governance.

- Index of govt. effectiveness and index of regulatory quality which was estimated by the World Bank have been negative.

- Pakistan seems to be under the influence of IMF.

- Reported Transparency International, Pakistan's index never crosses 30 which is the Corruption Perception Index. So this is what makes Pakistan very interesting to study the governance in relation with different variables.

\subsection{Board Size}

There are various studies which indicate that large board sizes are less effective as compared to small board size. Anderson and Reeb (2003); Coles et al. (2008) argued that the cost of problem solving and coordination cost are high in large board size as compared to small and which leads to difficulty in making discussion. Eisenberg et al. (1998); Lipton and Lorsch (1992); Yermack (1996) indicated that there is a tendency in enhancing the firm performance if board size is small 
because it reduces the possibility of free riding. Eisenberg et al. (1998) also argued that the effect of board size for new firm and various range of firm effect their explanation. Mak and Kusnadi (2005) argued that there is negative relation between board size and firm performance. On the ground of above study the research hypothesis is formed as:

$H_{1}$ : There is a significant negative impact of Board size on firm performance.

\subsection{Board Independence}

Possible deviation between management and shareholder has been reduced by effective mechanism if there is an involvement of independent director on the corporate board and it leads to higher firm performance. John and Senbet (1998) investigated that if the involvement of more non-executive director in corporate board becomes more independent board. The study indicates that there is the negative relation between firm performance and board independency (Bhagat and Black, 2001). The result showed in past studies if board depends on more executive director there is possibility of high agency conflict and low firm performance. Another study revealed that number of more independent board members involved improves the firm performance. So on the above discussion following hypothesis is formed as:

$\mathrm{H}_{2}$ : There is positive relationship between independent director and firm performance.

\subsection{CEO Duality}

CEO duality refers to when a single person holds two different positions like as a CEO and board chairman. According to Berg and Smith (1978); Ehikioya (2009) there is always higher agency cost and conflict of interest when the same person having two position as a CEO and chairman of board and it is recommended that two different people should not occupy two different position. Another study argued that CEO duality gives the opportunity to CEO to take decisions without any undue influence of official structure. Elsayed (2007), indicated that corporate performance does not affect by CEO duality. Another research study indicates that CEO duality decreases the operational and financial performance of the firm (Jensen and Meckling, 1976; Kyereboah-Coleman and Biekpe, 2006; Nazir et al., 2009). According to Stewardship theory CEO duality should be prefered as one person having both posts will have internal as well as external cost and will also lower transaction cost. As Pakistan rules and laws are not very strong and have more family ownerships so we can hypothesis as:
$\mathrm{H}_{3}$ : There is a positive relationship between CEO duality and performance of firm.

\subsection{Board Meeting}

Frequent annual meetings of board director measure the potency of board activity. Conger et al. (1998) pointed out that firm performance increases when board of director frequently meets annually and they work for the best interest of shareholders. Another study indicated that it is not necessary for board of directors to meet frequently because it leads to heavy cost such as wastage of managerial time and directors remuneration and due to limited time frame they cannot share their ideas effectively. As in Pakistan normally directors meeting does not hold that frequently when firms performance is good and if performance is in a slump or there are industrial sector crises the meeting rating goes higher to meet the problem, otherwise as the country has family ownership and has CEO duality, the chairperson and executives are already interconnected. Based on the above research findings we formulate the following hypothesis as:

$\mathrm{H}_{4}$ : There is a negative relationship between frequently annual board meeting and firm performance.

\subsection{Ownership Structure}

Over the last Fifty years, a question arises whether the structure of corporate Governance is decentralized or centralized. In decentralized system control of the company is not in one hand of management or different shareholder or stakeholder have a control on it. On the other hand, in centralized system corporate ownership structure based on centralized management in which one or two persons have a control on it. Corporate Governance varies according to corporate structure. In Pakistan ownership structure of corporate is centralized. Jalil et al. (2010) suggested that there is significant and positive impact of corporate governance on the firm performance and can be increased by improving the ownership structure. Mayer (1996) investigated that ownership and control discriminate appearance of different financial system. We believe Pakistani firms perform well in family ownership because if there is diversity in board the firm will not perform well because of board size diversity so based on the above finding we select the following hypothesis as:

$\mathrm{H}_{5}$ : There is a significant positive impact of family ownership structure on the firm performance.

\subsection{Female Board Member}

Many studies have been conducted on Female board member as a Corporate Governance. Dutta and 
Bose (2007) suggested that there is a diversified characteristic in board if female member is involved in board. Smith et al. (2006) suggested three factors by which female members play a vital role in board. First, the understanding level of female member is greater as compared to men and such understanding has a great impact on board decision effectively. Second, community perception is associated with female board member. Third, when female member is appointed, other board members better understand the environment of business. Past study reveals such female board members have positive impact on firm performance but in Pakistan as family ownerships are high and directors give shares to their own wives and children to take soft corner in taxes and moreover in Pakistan females are unlikely to take such positions. So following hypothesis is that:

$H_{6}$ : Female board members have no impact on firm performance.

\subsection{Board Education Level}

The board plays a vital role as internally controlled system in firm Corporate Governance (Fama and Jensen, 1983). Firm performances depend upon management effective decision which is supervised by board members. So each board member has knowledge of management decision making process. Effective management decisions enhance the firm performance which requires those board members whose quality or characteristic significantly contribute in the firm decisions (Adams and Ferreira, 2007; Fairchild and Li, 2005; Nicholson and Kiel, 2004). As resource base theory gives view of corporate governance that the directors are playing part to give resources to the firm to out-perform from its competitors, moreover transaction cost theory suggests the same that cost will be lower by having such people attached with the firm to take decisions. Based on the above research study, following hypothesis is that:

$H_{7}$ : There is a positive relationship between board educational level and firm performance.

\subsection{Boards Compensation}

According to Jensen and Meckling (1976) Agency problem plays a key objective role in advance Corporate Governance. Agency theory reveals that there is always constraint between management objective and shareholder interest. Sometimes management adopts those policies which protect themselves not in favor of shareholder interest. In order to overcome such problem, it is essential to pay the compensation to management as Corporate Governance mechanism which encourages them and positively contributes in firm performance (Jensen, 1993). Based on the above study, we develop hypothesis as given below:

$H_{8}$ : Board compensation has positive impact on firm performance.

\subsection{CEO's Compensation}

Agency theory tends to involve CEO with arm length transaction. This predicts positive link between CEO compensation and firm performance. But according to managerial power theory, if the balance of power shifts towards CEOs, the relationship will be inverse. In Pakistani context, CEOs are considered to be more powerful than the board because they may be either the heads of the controlling families or may have strong ties with controlling shareholders (Javid and Iqbal, 2008; Kamran and Shah, 2014). In Pakistan it is normal to see that CEOs compensation are hardly changed even in bad situations but it gets higher when firm performs better so:

$\mathrm{H}_{9}$ : CEO compensation has positive impact on firm performance but firm performance does not influence the CEO compensation.

\subsection{Boards Experience}

Board members experience plays an important role in firm performance. Past study argued that experience of those at their higher average age is greater than the younger age members and such experience is helpful in making better decision of firm. Carlsson and Karlsson (1970) argued that firm performance is influenced by risky decision which has been made by old age board members because they are more autocratic and intrusive with decision making. Wegge et al. (2008) argued that those board members who have more experience will better survive with business environment and feel comfortable in a group even in uncertain situation, which will boost the firm performance. On the above discussion we develop research hypothesis as below:

$H_{10}$ : There is a positive relationship between board experience and firm performance.

\section{Methodology}

\subsection{Scale}

$R O A=\beta 0+\beta 1$ BoardSize $+\beta 2$ BoardInd $+\beta 3$ CEOD $u+$ $\beta 4$ Meetings $+\beta 5$ Ownership $+\beta 6$ Gender $+\beta 7$ BoardEdu $+\beta 8$ BoardComp $+\beta 9$ CEOComp $+\beta 10$ BoardExp $+\varepsilon i$ 
ROA is the return on assets which represents accounting performance and is used as proxy to measure this dependent variable in our model, and it is measured as ratio of income before interest and taxes to total assets. Board size is measured as total number of total directors present in the board which is mentioned in the annual reports of firms. Code of corporategovernance in the Pakistan encourages the representation of independent directors which is mandatory requirement after year 2013. BoardInd shows board independence and to measure this variable normally researchers use ratio to non executive directors of the board size to measuring the board independence. CEODu is the CEO duality, and it is presented as a dummy variable to be measured by taking the value of 1 if CEO is the chairman among the BODs and 0 for otherwise.

Meeting represents the board meeting frequency of firm. Ownership represents the firm ownership structure where it is measured as state ownership measured as Code 1 if Government is owner and 0 otherwise and can also be measured as the Ratio of shares held by director divided by total outstanding shares of firm and if firm is institutional concentrated so researchers measure this variable as shares held by (promoter and banks where promoter can be foreign institutions or non-promoter institutions)/Total shares held by institutions and if family ownership is to be measured so researchers use ownership of largest shareholder (which may be certain percentage numbers of shares) as proxy for ownership concentration and it is dummy variable which takes value 1 for family firms and 0 otherwise.

Achleitner et al. (2014); Anderson and Reeb (2003) argued, to define family firm which fulfills any 1 of the 2 given conditions, (1) a person or family group holds at least $25 \%$ of voting right which may be measured as the percentage of shares owned (directly or indirectly) and (2) two or more family members sitting in the board. Gender means the female board members and it is measured as the total number of women present on the board. BoardEdu is Boards educational level and it is measured as number of directors holding masters degrees and because Pakistan is a developing country so education level master is well to measure other than in developing countries usually researchers take this variable measure as by postgraduate degrees. CEO and board compensation in Pakistan, stock options are non-existent. CEOs are seemed to be paid base salary, cash bonuses and other benefits, and postemployment benefits so researchers use total compensation in sum of all components of compensation including cash and non cash perks. BoardExp is board experience and is measured by the ages of directors sitting in the board.

\section{Discussion}

This study is descriptive in nature so discussion is based on theories that we discussed above and links with empirical evidence will be compiled in this portion. Empirical evidences from other studies have shown that in Pakistan reforms are made in 2013 corporate governance when regulatory body has set to shown all independent directors in their annual financial reports to encourage the investor's interest in financial markets to invest with safeguard and protected feelings when there are independent directors in the board and agency theory purposes the same style of corporate governance where independent directors are part of board so it results in higher the ROE and also market worth in terms of EPS (Jensen and Murphy, 1990; Kyereboah-Coleman and Biekpe, 2006). In different studies it is commonly viewed the assumptions of MPT managerial power theory in Pakistani firms where the CEO duality having in firm so CEO may become so powerful that power is shifted towards the $\mathrm{CEO}$ and he sets his own compensation bit higher than the market and enjoys his power distance and influences the other directors as well; so this is normally viewed in family owned firms and it results in lower ROE in firms but at same time we have seen according to the transaction cost theory which says the cost will be lower when CEO duality is in power and stewardship theory also purposes the idea of CEO duality and taking it as positive that managers are working for firm and making their interests align with corporation success so when there is CEO duality the person will have more internal as well as external information so he will perform well functions and lead towards success so in results the ROE will increase and due to ROE the firm will able to distribute more dividend and which will lead to higher the EPS.

It is found that the implications of stakeholder theory do not exist in Pakistan where this theory talks about the protection of all stakeholders which includes direct and indirect shareholders as Pakistan has more family concentrated firms so the rights of minority shareholders are often exploited. Researchers have also shown in their research that the problem in Pakistan is not about conflict between the management and owners but the real problem in agency problem is actually in large and small shareholders which the researchers have also shown in their empirical finings. Results are consistent with many other previous studies (Core et al., 1999; Croci et al., 2012; Fahlenbrach, 2008; Kamran and Shah, 2014; Van Essen et al., 2015).

As MPT managerial power theory purposes to set such compensation patterns that power shift does not go toward CEO in such a way that he will try to exploit the firm resources and we see in different and most recent study from Pakistan of Sheikh et al. (2018) in CEO duality if firm performance goes lower as ROE 
gets lower so the CEO pay will not be decreased in accordance; the results across different models need to be explored further using more variables on family characteristics as discussed by(Bertrand and Schoar, 2006). We also use ROE relation with directors pay patterns which shows by other researches that directors may get lower benefits so relation found inverse, resource base theory says firm should involve those directors in its board that may bring those resources which will be higher in cost if they were not directors so actually if those people will be directors who have those resources which are needed by firm so the firm will perform more better in all aspects because directors provide all resources to the firm's managers. Same is described by cost transaction theory which says the cost will be less in all means and these theories talk about empowering CEO and chairman by CEO duality. In Pakistan the female board member does not influence the ROE as cultural trends. Board experience and education matter when talking about the relations with ROE and even with EPS which reflects positive trend with market and firm performance in relation with board experience as argued by Wegge (2008).

We found no evidence in Pakistan for CSR as proxy for ethics theories impact on ROE as proxy for firm performance and even for market performance of firm which noted with EPS. So for future directions, we recommend to work in relation of ethics theories by creating proxy of CSR in relation with firm performance and market performance of firm. Due to time and resources limitation we were not able to work on all variables of governance so we have discussed only few of them in relation to firm performance.

\section{References}

Achleitner, A.-K., Günther, N., Kaserer, C., and Siciliano, G. (2014). Real earnings management and accrual-based earnings management in family firms. European Accounting $R e-$ view, 23(3):431-461.

Adams, R. B. and Ferreira, D. (2007). A theory of friendly boards. The journal of finance, 62(1):217-250.

Anderson, R. C. and Reeb, D. M. (2003). Founding-family ownership and firm performance: evidence from the s\&p 500. The journal of finance, 58(3):1301-1328.

Argyris, C. (1973). Some limits of rational man organizational theory. Public Administration Review, pages 253-267.

Bayless, M. (2009). The myth of executive compensation: do shareholders get what they pay for? Applied Financial Economics, 19(10):795-808.

Bebchuk, L. A. and Fried, J. M. (2003). Executive compensation as an agency problem. Journal of economic perspectives, 17(3):71-92.
Berg, S. V. and Smith, S. K. (1978). Ceo and board chairman: A quantitative study of dual vs. unitary board leadership. Directors and Boards, 3(1):34-39.

Bertrand, M. and Schoar, A. (2006). The role of family in family firms. Journal of economic perspectives, 20(2):73-96.

Bhagat, S. and Black, B. (2001). The non-correlation between board independence and long-term firm performance. $J$. CorP. l., 27:231.

Bhimani, A. (2008). Making corporate governance count: the fusion of ethics and economic rationality. Journal of Management $\mathcal{E}$ Governance, 12(2):135-147.

Boyd, B. K. (1994). Board control and ceo compensation. Strategic management journal, 15(5):335-344.

Brick, I. E., Palmon, O., and Wald, J. K. (2006). Ceo compensation, director compensation, and firm performance: Evidence of cronyism? Journal of Corporate Finance, 12(3):403423.

Buck, T., Liu, X., and Skovoroda, R. (2008). Top executive pay and firm performance in china. Journal of International Business Studies, 39(5):833-850.

Carlsson, G. and Karlsson, K. (1970). Age, cohorts and the generation of generations. American Sociological Review, pages 710-718.

Cheema, A. (2003). Corporate governance in pakistan: issues and concerns. The Journal, 8(2):7-19.

Clarke, T. (2004). Theories of corporate governance. The Philosophical Foundations of Corporate Governance, Oxon.

Clarkson, M. E. (1995). A stakeholder framework for analyzing and evaluating corporate social performance. Academy of management review, 20(1):92-117.

Coles, J. L., Daniel, N. D., and Naveen, L. (2008). Boards: Does one size fit all? Journal of financial economics, 87(2):329-356.

Conger, J. A., Finegold, D., and Lawler, E. E. (1998). Appraising boardroom performance. Harvard business review, 76:136-164.

Conyon, M. J. (2014). Executive compensation and board governance in us firms. The Economic Journal, 124(574):F60 F89.

Core, J. E., Holthausen, R. W., and Larcker, D. F. (1999). Corporate governance, chief executive officer compensation, and firm performance1. Journal of financial economics, 51(3):371-406.

Croci, E., Gonenc, H., and Ozkan, N. (2012). Ceo compensation, family control, and institutional investors in continental europe. Journal of Banking E Finance, 36(12):33183335 .

Cyert, R. M., March, J. G., et al. (1963). A behavioral theory of the firm. Englewood Cliffs, NJ, 2:169-187. 
Daily, C. M., Dalton, D. R., and Cannella Jr, A. A. (2003). Corporate governance: Decades of dialogue and data. Academy of management review, 28(3):371-382.

Davis, J. H., Schoorman, F. D., and Donaldson, L. (1997). Toward a stewardship theory of management. Academy of Management review, 22(1):20-47.

Denis, D. K. and McConnell, J. J. (2003). International corporate governance. Journal of financial and quantitative analysis, 38(1):1-36.

Donaldson, L. and Davis, J. H. (1991). Stewardship theory or agency theory: Ceo governance and shareholder returns. Australian Journal of management, 16(1):49-64.

Dutta, P. and Bose, S. (2007). Gender diversity in the boardroom and financial performance of commercial banks: Evidence from bangladesh.

Ehikioya, B. I. (2009). Corporate governance structure and firm performance in developing economies: evidence from nigeria. Corporate Governance: The international journal of business in society, 9(3):231-243.

Eisenberg, T., Sundgren, S., and Wells, M. T. (1998). Larger board size and decreasing firm value in small firms1. Journal of financial economics, 48(1):35-54.

Eisenhardt, K. M. (1989). Agency theory: An assessment and review. Academy of management review, 14(1):57-74.

Elsayed, K. (2007). Does ceo duality really affect corporate performance? Corporate Governance: an international review, 15(6):1203-1214.

Fahlenbrach, R. (2008). Shareholder rights, boards, and ceo compensation. Review of Finance, 13(1):81-113.

Fairchild, L. and Li, J. (2005). Director quality and firm performance. Financial Review, 40(2):257-279.

Fama, E. F. and Jensen, M. C. (1983). Separation of ownership and control. The journal of law and Economics, 26(2):301-325.

Freeman, R. E. (1999). Divergent stakeholder theory. Academy of management review, 24(2):233-236.

Gray, R., Owen, D., and Adams, C. (1996). Accounting $\mathcal{E}$ accountability: changes and challenges in corporate social and environmental reporting. Prentice Hall.

Hillman, A. J., Cannella, A. A., and Paetzold, R. L. (2000). The resource dependence role of corporate directors: Strategic adaptation of board composition in response to environmental change. Journal of Management studies, 37(2):235256.

Holmstrom, B. and Milgrom, P. (1994). The firm as an incentive system. The American economic review, pages 972-991.

Jalil, M. A., Azam, F., and Rahman, M. K. (2010). Implementation mechanism of ethics in business organizations. International Business Research, 3(4):145.
Javid, A. Y. and Iqbal, R. (2008). Ownership concentration, corporate governance and firm performance: Evidence from pakistan. The Pakistan Development Review, pages 643659.

Jensen, M. C. (1993). The modern industrial revolution, exit, and the failure of internal control systems. the Journal of Finance, 48(3):831-880.

Jensen, M. C. and Meckling, W. H. (1976). Theory of the firm: Managerial behavior, agency costs and ownership structure. Journal of financial economics, 3(4):305-360.

Jensen, M. C. and Murphy, K. J. (1990). Performance pay and top-management incentives. Journal of political economy, 98(2):225-264.

John, K. and Senbet, L. W. (1998). Corporate governance and board effectiveness1. Journal of Banking $\mathcal{E}$ Finance, 22(4):371-403.

Johnson, J. L., Daily, C. M., and Ellstrand, A. E. (1996). Boards of directors: A review and research agenda. Journal of management, 22(3):409-438.

Kamran, K. and Shah, A. (2014). The impact of corporate governance and ownership structure on earnings management practices: Evidence from listed companies in pakistan.

Kyereboah-Coleman, A. and Biekpe, N. (2006). The relationship between board size, board composition, ceo duality and firm performance: Experience from ghana. Corporate Ownership and Control, 4(2):114-122.

Lipton, M. and Lorsch, J. W. (1992). A modest proposal for improved corporate governance. The business lawyer, pages 59-77.

Mak, Y. T. and Kusnadi, Y. (2005). Size really matters: Further evidence on the negative relationship between board size and firm value. Pacific-Basin Finance Journal, 13(3):301-318.

Mayer, C. (1996). Corporate governance, competition and performance.

Murphy, K. J. (1999). Executive compensation. Handbook of labor economics, 3:2485-2563.

Nazir, M. S., Haque, A., and Ali, S. (2009). Can board mechanism affect the firm value in pakistan. Corporate Ownership and Control, 6(3):308-317.

Nicholson, G. J. and Kiel, G. C. (2004). Breakthrough board performance: how to harness your boards intellectual capital [1]. Corporate Governance: The international journal of business in society, 4(1):5-23.

Ozkan, N. (2011). Ceo compensation and firm performance: An empirical investigation of uk panel data. European Financial Management, 17(2):260-285.

Ross, S. A. (1973). The economic theory of agency: The principal's problem. The American Economic Review, 63(2):134139. 
Salancik, G. R. and Meindl, J. R. (1984). Corporate attributions as strategic illusions of management control. Administrative science quarterly, pages 238-254.

Sheikh, M. F., Shah, S. Z. A., and Akbar, S. (2018). Firm performance, corporate governance and executive compensation in pakistan. Applied Economics, 50(18):2012-2027.

Shleifer, A. and Vishny, R. W. (1997). A survey of corporate governance. The journal of finance, 52(2):737-783.

Smith, N., Smith, V., and Verner, M. (2006). Do women in top management affect firm performance? a panel study of 2,500 danish firms. International Journal of productivity and Performance management, 55(7):569-593.

Suchman, M. C. (1995). Managing legitimacy: Strategic and institutional approaches. Academy of management review, 20(3):571-610.

Sundaram, A. K. and Inkpen, A. C. (2004). The corporate objective revisited. Organization science, 15(3):350-363.

Tosi, H. L., Werner, S., Katz, J. P., and Gomez-Mejia, L. R. (2000). How much does performance matter? a metaanalysis of ceo pay studies. Journal of Management, 26(2):301-339.
Van Essen, M., Otten, J., and Carberry, E. J. (2015). Assessing managerial power theory: A meta-analytic approach to understanding the determinants of ceo compensation. Journal of Management, 41(1):164-202.

Wegge, J., Roth, C., Neubach, B., Schmidt, K.-H., and Kanfer, R. (2008). Age and gender diversity as determinants of performance and health in a public organization: the role of task complexity and group size. Journal of Applied Psychology, 93(6):1301.

Williamson, O. E. (1989). Transaction cost economics. Handbook of industrial organization, 1:135-182.

Williamson, O. E. (1996). The mechanisms of governance. Oxford University Press.

Yasser, Q. R. (2011). Corporate governance and performance (a case study for pakistani communication sector). International Journal of Trade, Economics and Finance, 2(3):204.

Yermack, D. (1996). Higher market valuation of companies with a small board of directors. Journal of financial economics, 40(2):185-211. 


\section{CONTRIBUTOR'S GUIDELINES}

The management of Jinnah Business Review (JBR) encourages researchers to prepare their articles in accordance with the following guidelines and submit their manuscripts online, preferably. Before submitting your articles online, you will have to transform your article in to our Journals template; and for this purpose, you can use a specimen provided for the article on our research center's website (www.jbrc.pk) as a base.

\section{AIMS AND SCOPE}

Jinnah Business Review (JBR) is the academic research journal of the Jinnah Business Research Center of Capital University of Science and Technology, Islamabad (Pakistan). The Journal publishes theoretical and empirical research papers in management, finance, human resource management, marketing and economics, and all other related disciplines of management and social sciences. Its primary focus is on empirical studies with an emphasis on the policy relevance of the findings.

JBRs goals are to inform the academic, business, and public policy communities of the results of relevant current research; to provide expert analysis of current events and reviews of literature in the field; and to add to the business literature material suitable for academics, executives, and professionals.

New innovative concepts, ideas and practices about businesses, industry, and management related disciplines are therefore welcomed. The submitted articles are undergone through a two-tiered review; the first evaluation is carried out by the JBR Editorial Advisory/Working Committee consisting of members from each relevant discipline, and the second review by peer referees and experts working in the related fields in Pakistan and abroad.

\section{INSTRUCTIONS FOR AUTHORS}

The Editors welcome preliminary inquiries about manuscripts for possible publication. There is no standard fixed length for articles, but a 1520 A4 pages, with 12-fonts and 1-line space article would suffice. Manuscripts should be prepared according to the following style rules (deviations from these rules can cause publication delays).

\section{Content, Length, and Formatting}

It is the author's responsibility to make the submitted paper readable, relevant, and interesting, before submission and consideration by referees. This require.

\section{Length}

All submitted papers must be formatted according to the instructions below, and must be no more than 15 20 US letter pages, as defined earlier. This page limit includes all parts of the paper: title, abstract, body, bibliography, appendices and tables.

\section{Abstract}

An abstract not exceeding 250 words comprising the following is required in the following format:

Authors name (s) and affiliation
a) Email address
b) Title and abstract content

The abstract content should clearly state:

a) Research questions and/or objectives

b) Methodology

c) Scope of investigation/findings

\section{Full paper}
a) A4 size paper
b) Margins must be 1 inch on all sides
c) Font size 12 Times New Roman (body text)
d) Title, subtitles, abstract and references single spaced; body text $1 \frac{1}{2}$ - line spaced
e) Referencing, graphics \& tables will be considered in the total page count.
f) Do not include page numbers, header \& footer.
g) Maximum 1520 pages
h) Other formatting details see next section 


\section{Tables and Figures}

a) All unessential tables and figures should be eliminated.

b) Tables must be submitted in Microsoft Word table format, and should be created using Times New Roman text, 10 point size. APA-style provided elsewhere must be preferred.

c) Figures must be clearly produced in black and white. All text included in figures should be Times New Roman (10 point minimum).

d) Each table and figure should fit on a single page. Tables and figures may be oriented horizontally (landscape) or vertically (portrait) within the allotted space.

e) Each table and figure should be submitted on a separate sheet and identified with a table or figure number and a descriptive title.

f) Legends and titles on tables and figures must be sufficiently descriptive such that they are understandable without reference to the text.

g) For data not generated by the author(s), the source of the data should be given (in short form) below the table or figure and listed in full in the references.

h) Every table and figure must be referred to in the text. Each table and figure will appear in the journal after its first mention in the text.

\section{File type}

All papers are to be submitted as a single MS WORD file, formatted for $8.5^{\prime \prime} \times 11^{\prime \prime}$ paper. It is essential that submitted papers print without difficulty on a variety of printers.

\section{Anonymity Requirements for Double-Blind Reviewing}

All research papers submitted to JBR will undergo a "double-blind" reviewing process: the program committee members and referees who review the paper will not know the identity of the authors. To ensure anonymity of authorship, authors must prepare their manuscript as follows:

a) Authors' names and affiliations must not appear on the title page or elsewhere in the paper.

b) You must also use care in referring to related past work, particularly your own, in the paper. The following types of statements must be avoided: In our previous work [1,2], we presented two algorithms for — In this paper, we build on that work by

\section{Footnotes and References}

a) Footnote material should be incorporated into the text whenever possible. If footnotes are necessary, the note number should be typed in the text and superscripted. The notes should be collected at the end of the text as endnotes.

b) References should be (a) integrated into the text in short form and (b) collected together at the end of the article. APA format needs to be followed. i) In-text, citations should be placed in parentheses and
noted as follows:

For book or academic journal - (last name of author[s], date); such as: (Hill, 1988); (Beatty, 1989; Feltham, et al. 1991; Leland \& Pyle, 1977).

If no author, cite journal, institution, or publisher. For works with three or more authors, list the first author followed by et al. as shown above. For multiple citations, alphabetize citations by first authors last name.

ii) The full bibliographic information in the references should be composed as follows:

For book - author[s]. year. book title. edition number [if applicable]. location: publisher. Such as: Yin, R.K. (2003). Case Study Research:

Design and Methods. 3rd Edition. Thousand Oaks, California: Sage Publications, Inc.

For edited volumeeditor[s] (ed[s].). year. book title. edition number [if applicable]. location: publisher.

Such as: Nelson, R.R.(ed.).(1993). National Systems of Innovations: A Comparative Analysis. Oxford: Oxford University Press.

For chapter in edited volume - author[s]. year. chapter title. in editor[s] (ed[s].). book title, pp. chapter page numbers. location: publisher.

Such as: Groenewegen, John and Jack Vromen (1997). Theory of the firm revisited: New and neoinstitutional perspectives. In Lars Magnusson and Jan Ottosson (eds.) Evolutionary Economics and Path Dependence, pp. 33-56. Cheltenham, UK: Edward Elgar.

For article in academic journal - author. year. article title. journal title. volume number (issue number): page numbers.

Such as: Black, J. S., Gregersen, H. B. \& Mendenhall, M.E. (1992). Toward a Theoretical Framework of Repatriation Adjustment. Journal of International Business Studies 23 (4): 737-760. 
The author(s) should make sure that there is a strict one-to-one correspondence between the in-text citations (including citations in footnotes, tables, and figures) and the list of references in the References.

\section{Copy Preparation}

JBR accepts manuscripts via internet or post or email. All hard-copy submissions must be accompanied by a disk or CD containing an electronic version of the manuscript. The manuscript should be prepared using a recent version of Microsoft Word and should utilize standard fonts and symbols. Ideally, such a manuscript should be formatted with regard to the following guidelines:

a) Do not use tabs except in tables.

b) Do not indent block quotations.

c) Do not hyphenate or otherwise break words across lines.

d) Use headings sparingly and logically. Do not use more than three levels of headings. Use consistent formatting for each heading level employed.

\section{Copyright Transfer}

a) Submission of a paper will be held to imply that it contains original unpublished work and is not being submitted for publication elsewhere.

b) Submission of a paper also implies that, upon acceptance of an article by the journal, the author(s) will transfer copyright of the article to the publisher. The transfer will ensure the widest possible dissemination of information.

c) It is understood that submission of the paper for publication has been approved by all of the authors and by the institution where the work was carried out; it is further understood that any person cited as a source of personal communications has approved such citation.

\section{Miscellaneous}

a) Papers must be in English. Use American spelling instead of British (e.g., labor, not labour). Use the American terms such as billion (one billion $=1,000,000,000$; one trillion = $1,000,000,000,000)$, rather than lakhs and crores.

b) Spell out all numbers from one to ninety-nine, unless:

i) the number contains a decimal point, e.g., 6.2 and 0.12 .

ii) the number precedes a percent sign or a unit of measure, e.g., $47 \%$ and $16 \mathrm{~m}$.

c) Italicize and define non-English words at their first occurrence; at subsequent occurrences, format the word in roman (no italicized) type.

d) A short abstract of the paper should always be included with the submission.

e) Please keep a copy of everything sent to JBR, both hard copy and electronic copy, and bear in mind that the electronic version received at JBR will be considered the master copy. The Editors do not accept responsibility for damage to or loss of submitted papers or electronic media.

f) A short note listing each authors institutional affiliation, current address, telephone numbers, email address, and other relevant biographical information, including publications and a photograph should be provided.

g) Any manuscript that does not conform to the above instructions may be returned for the necessary revision before publication.

h) Each author is entitled to one copy of the issue in which his or her article appears.

\section{Note:}

Editor reserves the right to amend, abridge or otherwise alter the contents of the paper to make it suitable for publication. However every endeavor will be made not to affect the spirit or effectiveness of the paper. 



\section{J I N N A H \\ BUSINESS RESEARCH CENTER}

Capital University of Science and Technology

Islamabad Expressway, Kahuta Road, Zone-V, 